INSTITUTO DE PESQUISAS ENERGÉTICAS E NUCLEARES

Autarquia associada à Universidade de São Paulo

EMBALAGENS ATIVAS DE FONTE RENOVÁVEL

NATÁLIA NAIME

Dissertação apresentada como parte dos requisitos para obtenção do Grau de Mestre em Ciências na Área de Tecnologia Nuclear - Materiais.

Orientador:

Prof. Dr. Ademar Benévolo Lugão

SÃO PAULO 


\section{INSTITUTO DE PESQUISAS ENERGÉTICAS E NUCLEARES}

Autarquia associada à Universidade de São Paulo

EMBALAGENS ATIVAS DE FONTE RENOVÁVEL

NATÁLIA NAIME

Dissertação apresentada como parte dos requisitos para obtenção do Grau de Mestre em Ciências na Área de Tecnologia Nuclear - Materiais.

Orientador:

Prof. Dr. Ademar Benévolo Lugão

SÃo PAULO 
Dedico este trabalho a todos interessados em "praticidade com qualidade". Mas desde que respeitem o meio ambiente! 


\section{AGRADECIMENTOS}

Agradeço primeiramente aos Drs. Ademar Benévolo Lugão e Patrícia Ponce pelos ensinamentos e orientações, contribuindo para que este trabalho se tornasse "dissertação".

Aos Drs. Luis Filipe C. P. Lima e Antônio Jedson Caldeira Brant pela sabedoria e sugestões transmitidas.

Sou grata pela oportunidade de conhecer pessoas muito queridas no Centro de Química e Meio Ambiente do IPEN (Débora, Elen, Maria, Pedro, Henrique, Sandra, Liana, Beth, Mara, Renata), responsáveis, algumas delas, por transformar - ao longo destes dois anos - um simples "oi” em verdadeira amizade. Não poderia deixar de mencionar aqui, embora mais uma vez, a Dra. Patrícia Ponce, da qual tenho um enorme carinho e admiração!

Agradeço as minhas fiéis companheiras de faculdade e mestrado, Adriana Fabbri e Juliana Nunes.

Os amigos da manutenção do Centro de Química e Meio Ambiente do IPEN, Edson Takeshi e João Batista, pelo esforço e boa vontade.

Ao Laboratório de Engenharia de Alimentos da POLI (Profa. Carmen Tadini e Ana) por disponibilizar o texturômetro para as análises das propriedades mecânicas das espumas.

Ao Prof. Gil Anderi da Silva pela ajuda no estudo de ACV.

À EMBRARAD (Empresa Brasileira de Radiações).

À Compacta Print Ltda., por permitir a extrusão de algumas formulações de massa.

À CNEN (Comissão Nacional de Energia Nuclear) pelo apoio financeiro.

E, como não poderia faltar, quero agradecer toda a minha família. Em especial, meu pai pela paciência, minha mãe pelo seu silêncio - porque "fala pelos cotovelos" - meu irmão (talvez pela paciência também... não sei...) e minha irmã gêmea que, apesar de infelizmente já estar em outro plano, tenho certeza de que me deu - e continua dando muita força, luz e boas vibrações para eu enfrentar a saudade (e que saudade!!!) e superar as dificuldades! 


\title{
EMBALAGENS ATIVAS DE FONTE RENOVÁVEL
}

\author{
Natália Naime
}

\section{RESUMO}

Foram desenvolvidas embalagens biodegradáveis ativas tipo espuma, obtidas a partir de fécula de mandioca, capazes de aumentar a vida-de-prateleira de frutas minimamente processadas. Para tanto, agentes ativos que evitam a proliferação de fungos, a perda de peso e, também, forneçam uma indicação visual (mudança de cor da embalagem) da qualidade do produto embalado, foram adicionados às embalagens de fonte renovável. As espumas foram obtidas pelos processos de extrusão e termoprensagem de uma massa de fécula, gel (fécula suspensa em água) e aditivos (plastificantes e/ou agentes ativos). As formulações de espumas variaram quanto: ao tipo e concentrações de plastificantes (glicerol e polietilenoglicol - PEG 300); às quantidades de sólido (fécula de mandioca em pó); aos diferentes tratamentos da fécula (modificações química - por acetilação - e físicas - irradiação e pré-gelatinização); à procedência da fécula (da Bahia e do Paraná); ao reaproveitamento de espumas descartadas; às diferentes concentrações de agentes ativos (ácido l-ascórbico, cloreto de cálcio, sorbato de potássio e permanganato de potássio) e quanto à adição de corantes naturais (extratos de beterraba e repolho roxo). Foram avaliadas, principalmente, as propriedades mecânicas e de barreira das diferentes formulações de espumas de fécula de mandioca. Os resultados indicaram que quanto maior a concentração de fécula mais resistente é a espuma. As espumas contendo o plastificante PEG 300 se mostraram bastante flexíveis, apresentaram boa resistência à ruptura e absorveram pouca água. A pré-gelatinização da fécula proporcionou melhores propriedades mecânicas e de barreira para as espumas em relação aos outros tratamentos dados à fécula de mandioca. Já a adição de agentes ativos à massa não proporcionou tais melhoras às embalagens. As espumas de fécula de mandioca produzidas pelo processo de extrusão seguido de termoprensagem foram mais resistentes à ruptura do que as produzidas somente por termoprensagem. 


\title{
ACTIVE PACKAGING FROM RENEWABLE SOURCE
}

\author{
Natália Naime
}

\begin{abstract}
Active biodegradable packaging foams type were developed, obtained from cassava starch, to increase the shelf-life of minimally processed fruits. For this, active agents that prevent the proliferation of fungi, weight loss and, still, provide a visual indication (change of packaging color) of the packaged product quality, were added to the renewable packaging. The foams were obtained by extrusion and thermopressing processes of a mixture of starch, gel (starch suspended in water) and additives (plasticizers and/or active agents). The foams formulations varied as: the type and concentrations of plasticizers (glycerol and polyethylene glycol - PEG 300); the concentrations of solid (cassava starch powder); the different treatments of starch (chemical, for acetylation, and physical modifications - radiation and pre-gelatinization); the starch suppliers (from Bahia and Paraná); the reuse of discarded foams; the different active agents (1-ascorbic acid, calcium chloride, potassium sorbate and potassium permanganate) and the addition of natural dyes (beet and cabbage extracts). It was evaluated, mainly, the mechanical and barrier properties of the different formulations of cassava starch foams. The results indicated that the higher starch concentration more resistant become the foam. The foams containing the plasticizer PEG 300 proved to be very flexible, had good tensile strength and absorbed less water. The pre-gelatinization of starch provided better mechanical and barrier properties to foams in comparison with other treatments of cassava starch. The addition of active agents to the mix did not provide such improvements to packaging. The cassava starch foams produced by extrusion followed by thermopressing were more resistant to breakage than those produced only by thermopressing.
\end{abstract}




\section{SUMÁRIO}

Página

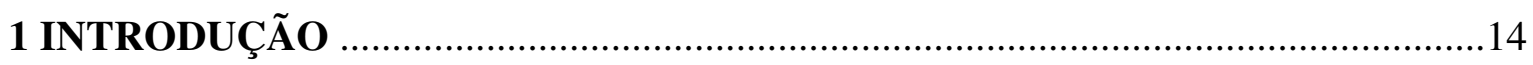

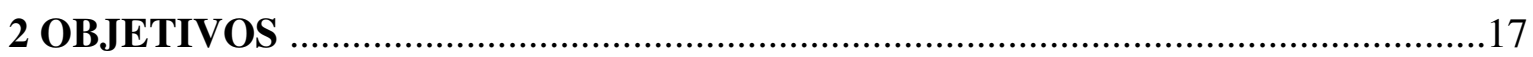

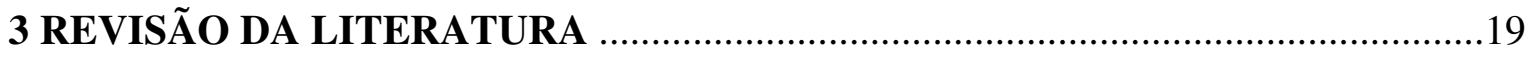

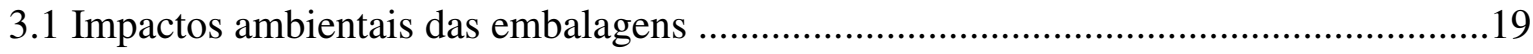

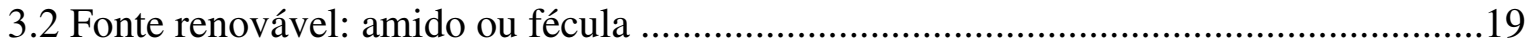

3.3 Embalagens ativas de fonte renovável ....................................................................21

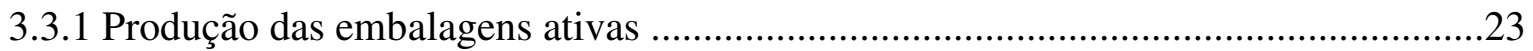

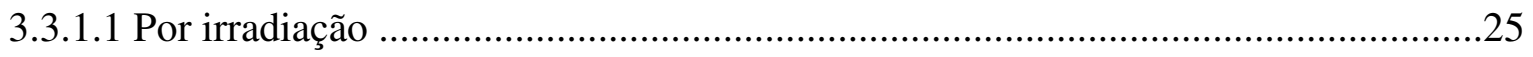

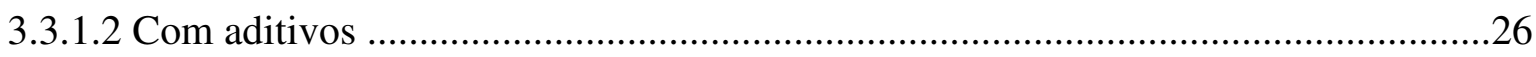

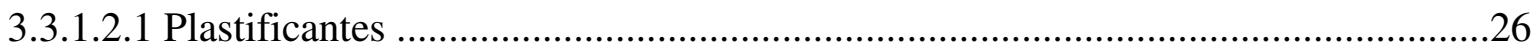

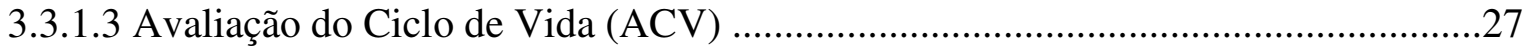

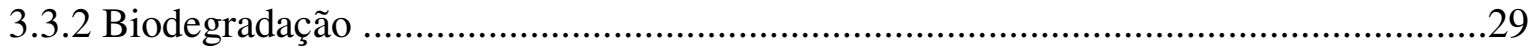

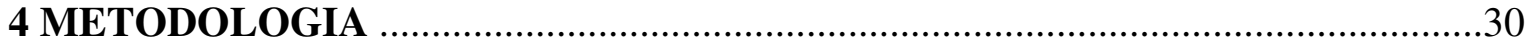

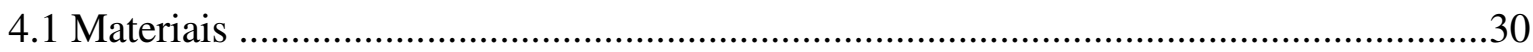

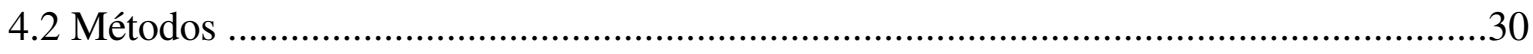

4.2.1 Produção das embalagens de fécula de mandioca tipo espuma .................................30

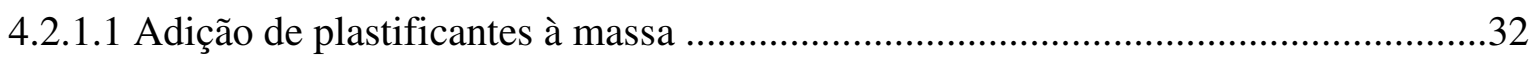

4.2.1.2 Concentrações de sólido (fécula de mandioca em pó) ............................................33

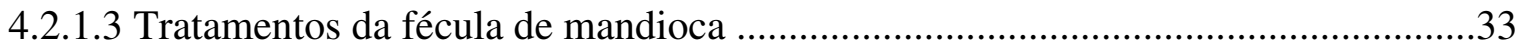

4.2.1.3.1 Modificação química da fécula ............................................................................33

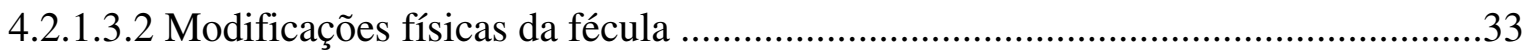

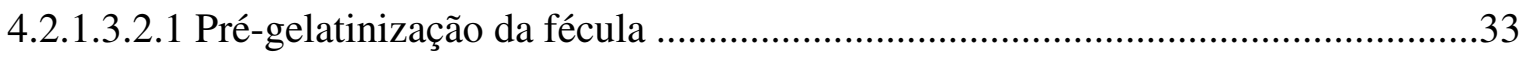

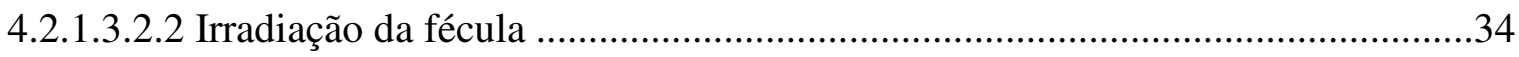

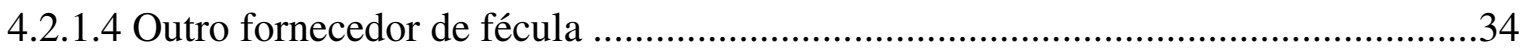

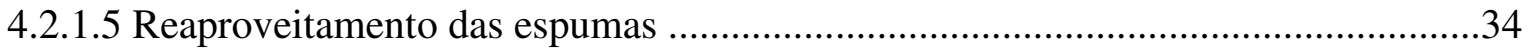

4.2.1.6 Estudo da Avaliação do Ciclo de Vida (ACV) .......................................................35

4.2.1.7 Produção das embalagens ativas de fécula de mandioca tipo espuma ....................35 


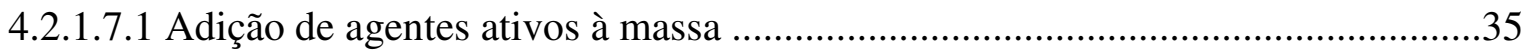

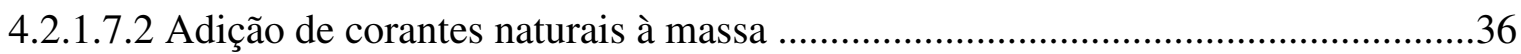

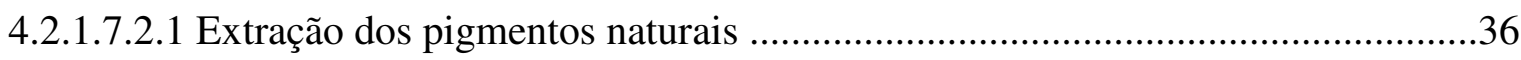

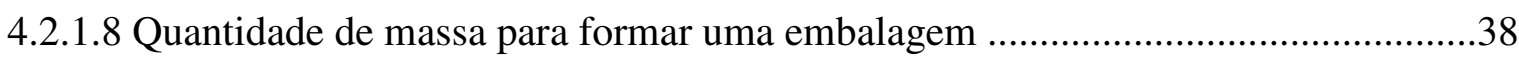

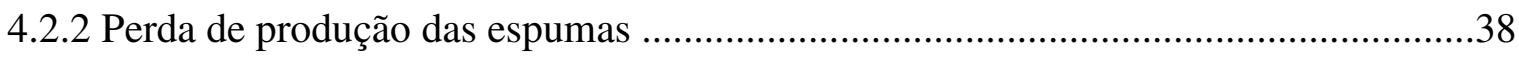

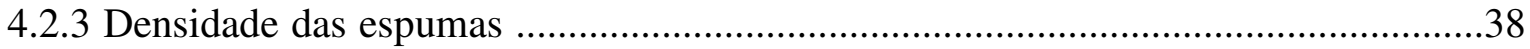

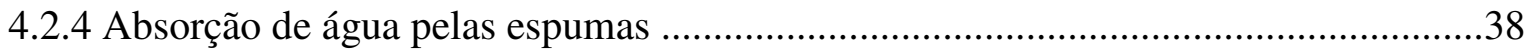

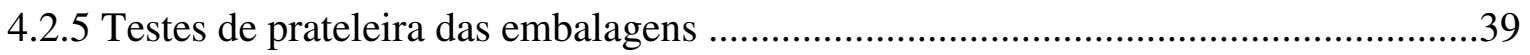

4.2.6 Ensaios de resistência à tração e alongamento na ruptura das embalagens ................40

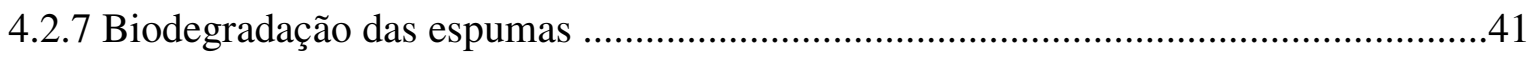

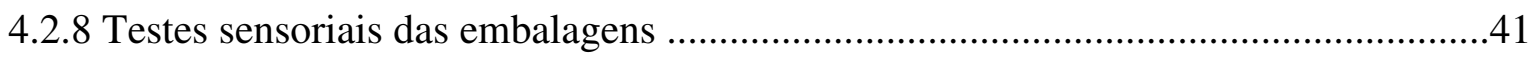

4.2.8.1 Análises físico-químicas das frutas ......................................................................42

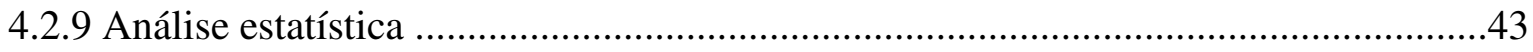

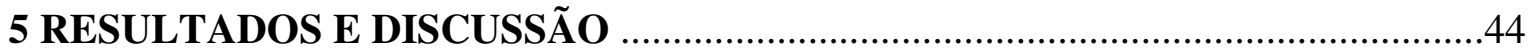

5.1 Produção das embalagens de fécula de mandioca tipo espuma ...................................44

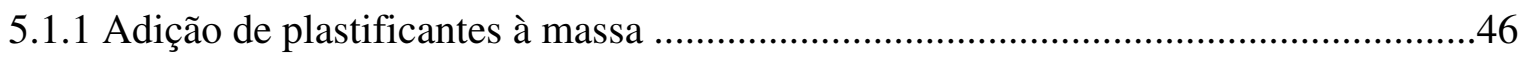

5.1.2 Variação da quantidade de sólidos (fécula de mandioca em pó) na massa..................53

5.1.3 Tratamentos da fécula de mandioca, uso de outro fornecedor de fécula e

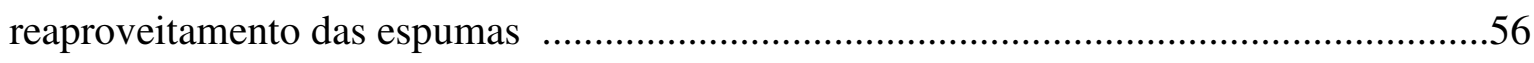

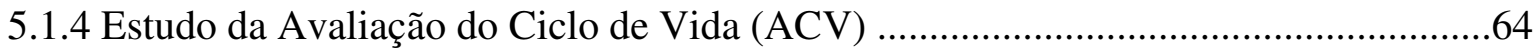

5.1.5 Produção das embalagens ativas de fécula de mandioca tipo espuma .......................69

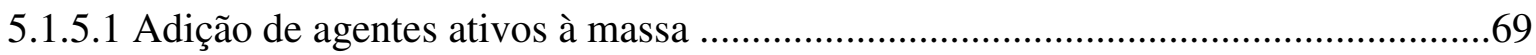

5.1.5.2 Adição de corantes naturais à massa ..................................................................... 80

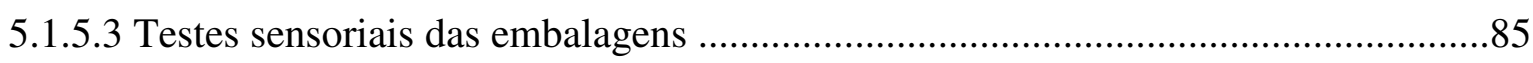

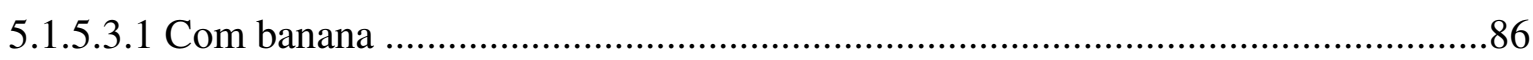

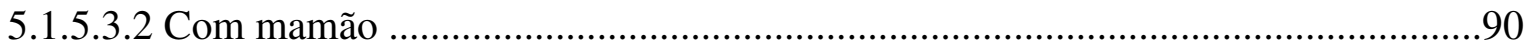

5.1.5.4 Extrusão versus Termoprensagem para obtenção das embalagens ativas de fécula

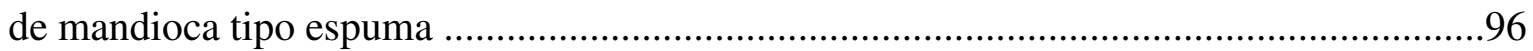

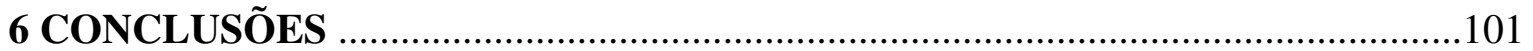

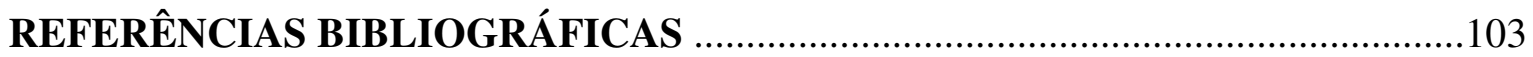




\section{LISTA DE TABELAS}

Página

TABELA 1 - Coloração dos pigmentos da beterraba e do repolho roxo em água destilada, em função do $\mathrm{pH}$ .38

TABELA 2 - Resultados da absorção de água pelas espumas de fécula de mandioca (55\% de fécula) sem e com plastificantes, nas diferentes concentrações, e pelo isopor

TABELA 3 - Resultados da perda de produção e da densidade das espumas de fécula de mandioca, sem e com plastificantes, na concentração de $2 \%$ .50

TABELA 4 - Resultados da quantidade média de massa necessária para formar uma embalagem (espuma), da perda de produção, da densidade, da solubilidade e dos testes mecânicos (resistência à tração e alongamento na ruptura) das espumas de diferentes concentrações de fécula de mandioca (em pó)

TABELA 5 - Resultados da quantidade média de massa necessária para formar uma embalagem (espuma), da perda de produção, da densidade e da solubilidade das espumas sem e com diferentes tratamentos da fécula de mandioca e do isopor

TABELA 6 - Análise de Inventário dos dois processos de obtenção das embalagens (espumas) e relação entre ambos

TABELA 7 - Resultados da quantidade média de massa necessária para formar uma embalagem (espuma), da perda de produção, da densidade e da solubilidade das espumas sem e com agentes ativos, em diferentes concentrações, adicionados à massa por ambos os métodos estudados .75

TABELA 8 - Resultados da absorção de água pelo isopor e pelas espumas de fécula de mandioca sem e com corantes naturais e em diferentes concentrações

TABELA 9 - pH das fatias de banana (armazenadas em geladeira), seladas com espumas ativas de fécula de mandioca e isopor, ao longo de 7 dias

TABELA 10 - pH dos pedaços de mamão (armazenados em geladeira), selados com espumas ativas de fécula de mandioca, isopor e polietileno, ao longo de 14 dias . .95 
TABELA 11 - Pesos das espumas sem e com ativos (permanganato de potássio, sorbato de potássio e extratos naturais de beterraba e repolho roxo) após termoprensagem de quantidades de massa pura e massa extrusada 


\section{LISTA DE FIGURAS}

Página

FIGURA 1 - Estrutura química da amilose e da amilopectina .......................................20

FIGURA 2 - Foto ilustrativa da mandioca (Manihot esculenta crantz) ...........................21

FIGURA 3 - Desenho esquemático de uma extrusora mono rosca ..................................24

FIGURA 4 - Desenho esquemático da termoprensagem ...............................................24

FIGURA 5 - Representação das etapas consideradas em um estudo de ACV ..................28

FIGURA 6 - Fotografias dos misturadores de laboratório com capacidade para dois e

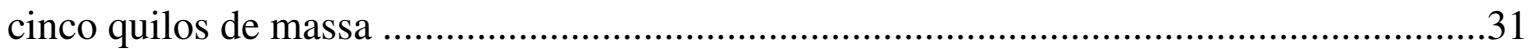

FIGURA 7 - Extrusão da massa em extrusora mono rosca equipada com três zonas de aquecimento

FIGURA 8 - Produção das espumas de fécula de mandioca por termoprensagem, em forma de potes 32

FIGURA 9 - Produção das espumas de fécula de mandioca por termoprensagem, em forma de placas retangulares .32

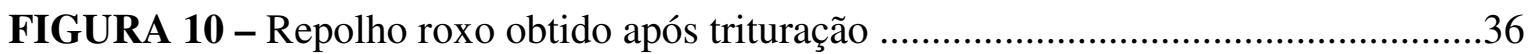

FIGURA 11 - Aparato para extração do pigmento natural de repolho roxo .37

FIGURA 12 - Fotografias da coloração obtida dos extratos de beterraba e repolho roxo em função do $\mathrm{pH}$

FIGURA 13 - Fotografia das amostras de embalagens (espumas) armazenadas em estufa com termômetro e medidor de umidade

FIGURA 14 - Fotografia do ensaio de resistência à tração e alongamento na ruptura das espumas

FIGURA 15 - Fotografias do método de estudo de biodegradação das espumas por perda de massa

FIGURA 16 - Fotografias das frutas (banana e mamão) cortadas e armazenadas em pirex revestidos por papel filme

FIGURA 17 - Fotografia das frutas acondicionadas em potes de polipropileno e em embalagens de polietileno, armazenados em geladeira 
FIGURA 18 - Espumas sem plastificantes, com 55\% de fécula de mandioca, em forma de placa, obtidas em laboratório

FIGURA 19 - Resistência à tração e alongamento na ruptura das espumas sem plastificantes, com $55 \%$ de fécula de mandioca, e do isopor

FIGURA 20 - Espumas de fécula de mandioca seca e com água 45

FIGURA 21 - Resistência à tração e alongamento na ruptura das espumas de fécula de mandioca (55\% de fécula) sem e com plastificantes, nas diferentes concentrações

FIGURA 22 - Teor de umidade das espumas de fécula de mandioca sem e com plastificantes (na concentração de $2 \%$ ) ao longo dos dias, sem controle de temperatura e umidade e com controle de temperatura e umidade

FIGURA 23 - Perda de massa das espumas de fécula de mandioca sem e com plastificantes, na concentração de $2 \%$

FIGURA 24 - Perda de massa das espumas de fécula de mandioca em diferentes concentrações de sólido (fécula) .56

FIGURA 25 - Resistência à tração e alongamento na ruptura das espumas sem tratamento, com diferentes tratamentos, de diferentes fornecedores de fécula de mandioca e das espumas reaproveitadas

FIGURA 26 - Resistência à tração e alongamento na ruptura das espumas contendo $10 \% \mathrm{e}$ $100 \%$ de fécula de mandioca irradiada

FIGURA 27 - Principais etapas do ciclo de vida das espumas de fécula de mandioca, obtidas por termoprensagem, e sua fronteira de estudo

FIGURA 28 - Principais etapas do ciclo de vida das espumas de fécula de mandioca, obtidas por extrusão seguida de termoprensagem, e sua fronteira de estudo

FIGURA 29 - Aspecto visual das espumas de fécula de mandioca com cloreto de cálcio, sorbato de potássio, permanganato de potássio e ácido l-ascórbico

FIGURA 30 - Resistência à tração e alongamento na ruptura das espumas de fécula de mandioca sem ativos e com diferentes concentrações de ativos, não incorporados ao gel (método 1)

FIGURA 31 - Resistência à tração e alongamento na ruptura das espumas de fécula de mandioca sem ativos e contendo ativos na concentração de $15 \%$, incorporados ao gel (método 2) .73

FIGURA 32 - Teor de umidade das espumas de fécula de mandioca sem e com $15 \%$ de agentes ativos, adicionados à massa pelos métodos 1 (ativos não incorporados ao gel) e 2 
(ativos incorporados ao gel) - ao longo dos dias, sem controle de temperatura e umidade e com controle de temperatura e umidade

FIGURA 33 - Perda de massa das espumas de fécula de mandioca sem e com $15 \%$ de agentes ativos, adicionados à massa pelos métodos 1 (ativos não incorporados ao gel) e 2 (ativos incorporados ao gel)

FIGURA 34 - Espumas de fécula de mandioca formuladas com extratos de beterraba e repolho roxo

FIGURA 35 - Espuma de fécula de mandioca inteligente, contendo extrato de repolho roxo como indicador de $\mathrm{pH}$

FIGURA 36 - Espuma de fécula de mandioca inteligente, contendo extrato de beterraba como indicador de $\mathrm{pH}$

FIGURA 37 - Resistência à tração e alongamento na ruptura das espumas de fécula de mandioca com corantes naturais e sem corantes

FIGURA 38 - Redução de massa fresca dos pedaços de banana minimamente processados, armazenados a $10^{\circ} \mathrm{C}$

FIGURA 39 - Vida útil de comercialização de bananas minimamente processadas e armazenadas a $10^{\circ} \mathrm{C}$ em espumas de fécula de mandioca sem ativos e em isopor

FIGURA 40 - Redução de massa fresca dos pedaços de mamão minimamente processados, armazenados a $10^{\circ} \mathrm{C}$

FIGURA 41 - Vida útil de comercialização de mamões minimamente processados, armazenados em potes de polipropileno e selados com espumas de fécula de mandioca sem ativos e com embalagens convencionais de isopor e polietileno

FIGURA 42 - Vida útil de comercialização de mamões minimamente processados, armazenados a $10^{\circ} \mathrm{C}$ em potes de polipropileno, e selados com espumas ativas de fécula de mandioca e embalagens convencionais de isopor e polietileno

FIGURA 43 - Ausência de bolor nos pedaços de mamão cobertos pelas espumas de fécula de mandioca contendo permanganato de potássio e sorbato de potássio; e formação de bolor em mamão coberto por isopor e em embalagem de polietileno

FIGURA 44 - Mudança de cor da espuma contendo extrato natural de repolho roxo após 14 dias de refrigeração do pedaço de mamão em contato com a espuma . .95

FIGURA 45 - Espumas sem ativos obtidas por termoprensagem de mesmas quantidades de massa pura e massa extrusada 
FIGURA 46 - Espumas com sorbato de potássio, incorporado ao gel, obtidas por termoprensagem de mesmas quantidades de massa pura e massa extrusada 98 FIGURA 47 - Resistência à tração e alongamento na ruptura das espumas de fécula de mandioca com e sem ativos, obtidas pelos processos de termoprensagem e extrusão seguida de termoprensagem 


\section{INTRODUÇÃO}

As primeiras "embalagens" surgiram há mais de 10 mil anos e serviam apenas como "copos" ou para estocar alimentos; eram cascas de coco ou conchas do mar, usados em estado natural, sem qualquer melhora. Tigelas de madeira, cestas de fibras naturais, bolsas de peles de animais e potes de barro, entre outros "avós" dos modernos invólucros e vasilhames, fizeram parte de uma segunda geração de formas e técnicas de embalagem. A primeira matéria-prima usada em maior escala para a produção de embalagens foi o vidro. Por volta do primeiro século depois de Cristo, os artesãos sírios descobriram que o vidro fundido poderia ser soprado para produzir utensílios de diversos formatos, tamanhos e espessuras. Essa técnica permitia a produção em massa de recipientes de vários formatos e tamanhos. Embora o uso de metais como cobre, ferro e estanho tenha surgido na mesma época em que a cerâmica de barro, foi somente nos tempos modernos que eles começaram a ter um papel importante para a produção de embalagens (ABRE, 2010).

Durante a $2^{\text {a }}$ Guerra Mundial difundiram-se as latas de estanho e aço, mas foi o alumínio a matéria-prima que substituiu primordialmente a folha de flandres. Em 1959, a Adolph Coors Company iniciou a venda de bebidas em latas de alumínio. Depois da guerra surgiram diversas inovações na produção de embalagens, como aquelas feitas com papel e papelão - capazes de acondicionar diversos tipos de produtos, além de serem fáceis de transportar, estocar e empilhar -, e com plástico (poliéster, polietileno, polipropileno, entre outros) (ABRE, 2010).

A produção de embalagens plásticas cresceu a partir de 1960. O plástico é um dos derivados de petróleo mais conhecido e usado, cujo uso generalizado agravou o problema do lixo. É utilizado, por exemplo, como embalagem descartável em alimentos e bebidas (com destaque à embalagem de politereftalato de etileno - PET), e sacos de lixo. Seu baixo custo de produção e sua versatilidade, porém, tornaram esse tipo de produto bastante popular (ABAM, 2006).

As matérias-primas descobertas até então passaram a ser combinadas. É o caso das caixas de cartão que, ao receberem uma camada de resina plástica, tornam-se 
impermeáveis e podem ser utilizadas para embalar líquidos, tais como molhos, leite, sucos, etc.

Até 1945, poucos produtos eram comercializados pré-acondicionados em nosso país. Na indústria de alimentos, os principais eram o extrato de tomate, o café torrado e moído, o leite em garrafa, o açúcar refinado, o vinagre e o óleo de semente de algodão (ABRE, 2010).

Tradicionalmente, os materiais de embalagens têm sido selecionados para ter uma interação com o alimento que acondicionam, constituindo assim barreiras inertes (Da Cunha et al., 2007). Entretanto, nas últimas décadas diversos sistemas de embalagem têm sido desenvolvidos para interagir com o alimento, mas de forma desejável - são as embalagens ativas, geralmente planejadas para alterar determinadas características no produto (Soares, 1998). As embalagens ativas vêm sendo usadas em grande número de produtos alimentícios, tais como: pães, bolos, biscoitos, pizza, massa fresca, croissant, queijo, peixe, carnes (curadas, desidratadas, defumadas), café, chá, leite em pó, feijão, frutas desidratadas, farinhas, vinhos, "snacks", frutas, hortaliças, legumes, etc. Cada um desses produtos tem diferentes mecanismos de deterioração, que deverão ser entendidos para que se possa definir uma embalagem ativa (Vermeiren et al., 1999). Dentre as inúmeras embalagens ativas, podem-se destacar os filmes antimicrobianos, as embalagens com atmosferas modificadas, absorvedores de oxigênio e de etileno, absorvedores e geradores de $\mathrm{CO}_{2}$, reguladores de umidade, liberadores de aditivos, liberadores e/ou absorvedores de sabores e odores, indicadores de temperatura, incorporadores de enzimas, absorvedores de radiação (Appendini e Hotchkiss, 2002; Brandão, 2001; Han, 2010) e até mesmo embalagens que mudam de cor para informar o consumidor de que o alimento está estragado.

Nos anos 1980, por uma preocupação com o destino das embalagens após o consumo (Amadeu et al., 2005; Berthier, 2003; Pieters, 1991), houve um crescimento da busca por alternativas em reduzir a quantidade de lixo. Na verdade, a embalagem tem sido o principal ponto de discussão de políticas públicas e grupos ambientalistas rumo à solução do gerenciamento dos resíduos sólidos urbanos (Fonteyne, 2000; Levy, 2000; Palhares, 2003; Williamson, 2000). Sob um ponto de vista mais amplo, a embalagem não é somente o invólucro para um produto, ela representa a filosofia ambiental da empresa (Wasik, 1996; Woods e Beynon, 2000).

Dentre os resíduos, o destaque dos últimos anos é para as embalagens plásticas. $\mathrm{O}$ consumo de plásticos no Brasil e no mundo vem aumentando há décadas, numa clara 
demonstração do enorme sucesso conseguido por esse material nas mais variadas aplicações (ABIPLAST, 2006). As características típicas do plástico, como seu baixo custo, baixo peso, boa resistência mecânica, impermeabilidade, transparência, capacidade de coloração e impressão, lhe conferiram trunfos irresistíveis para seu uso massivo na forma de embalagens, tornando-se uma aplicação extremamente importante numa sociedade voltada para o consumo (Barrett e Bickerstaffe, 2000; Piva e Wiebeck, 2004).

A grande maioria dos materiais plásticos utilizados para compor as embalagens de alimentos possui tecnologia para a sua reciclagem (Piva e Wiebeck, 2004; Zanin e Mancini, 2004). A cada dia, novos conhecimentos são adquiridos, visando um reaproveitamento adequado dos materiais utilizados para a proteção e a segurança do alimento industrializado. Por outro lado, apesar de existir possibilidade técnica para a reciclagem, alguns materiais, como o poliestireno expandido (isopor), são considerados não recicláveis por falta de interesse de mercado (IDEC, 2006).

Plásticos biodegradáveis são degradados por microrganismos quando descartados no solo. A diferença destes (biodegradáveis) em relação aos que têm origem no petróleo está no tempo de degradação. Estes, por sua vez, dependem do que foi adicionado à resina considerada biodegradável. A diferença é grande: vai de meses (6 a 12 meses) contra 40 a 50 anos ou até 200 anos no caso dos polímeros sintéticos, tais como o politereftalato de etileno (PET) e o poliestireno expandido (isopor) (Coutinho et al., 2004).

Assim, as alternativas reais para embalagens ecologicamente corretas, capazes de substituir os plásticos tradicionais fabricados à base de petróleo, são os polímeros renováveis, tais como a celulose e o amido, extraídos de plantas superiores, e os polímeros extraídos de algas e de alguns microrganismos (PHB, PLA, etc.).

Na América do Sul, ganha destaque a utilização do amido/fécula de mandioca como fonte fornecedora de polímero; isso se deve a sua versatilidade e, principalmente, seu baixo custo. Fécula e amido são sinônimos, entretanto, no Brasil, costuma-se chamar de amido a substância amilácea encontrada nos órgãos aéreos, tais como: milho, arroz, trigo, etc. e de fécula aquela encontrada nas raízes e tubérculos, como: mandioca, cará, batata, etc. O Brasil é o segundo maior produtor mundial de mandioca (Manihot esculenta crantz), sendo cultivada em todos os estados brasileiros.

Com base em tudo que foi exposto, considera-se de grande interesse, sob diversos pontos de vista, o desenvolvimento de embalagens ativas a partir da fécula de mandioca como fonte renovável. 


\section{OBJETIVOS}

Este projeto tem por objetivo o desenvolvimento de uma embalagem biodegradável ativa tipo espuma, obtida por extrusão e termoprensagem, a partir de fonte renovável (fécula de mandioca). A embalagem irá aumentar a vida de prateleira de frutas minimamente processadas. Para tanto, agentes ativos que evitam a proliferação de fungos e, também, a perda de peso, além de fornecer uma indicação visual (mudança de cor da embalagem) da qualidade do produto embalado serão adicionados às embalagens de fonte renovável.

Os objetivos específicos deste projeto são:

$1^{\circ}$ ) Desenvolver um processo de produção de espumas de fécula de mandioca, por meio da extrusão e termoprensagem, para a fabricação de embalagens ativas tipo espuma. Verificar a influência da quantidade de fécula, do tipo de tratamento dado à fécula (modificações químicas e físicas da fécula) e do reaproveitamento de espumas nas propriedades mecânicas e de barreira do produto final;

$2^{\circ}$ ) a) Estudar as propriedades mecânicas e de barreira das espumas por meio da adição de plastificantes, como glicerol e polietilenoglicol (PEG 300). b) Verificar a influência dos agentes ativos (cloreto de cálcio, sorbato de potássio, permanganato de potássio e ácido l-ascórbico) no tempo de prateleira e nas propriedades mecânicas e de barreira das espumas;

$3^{\circ}$ ) Estudar as propriedades de barreira das espumas ativas durante seu armazenamento à temperatura ambiente e, em estufa, com temperatura e umidade controladas;

$\left.4^{\circ}\right)$ Estudar a estabilidade e as propriedades mecânicas e de barreira das espumas de fécula de mandioca em função da irradiação da fécula com doses de 3, 6, 12 e 25 kGy;

$5^{\circ}$ ) Comparar as propriedades mecânicas e de barreira das embalagens ativas de fonte renovável às propriedades das embalagens convencionais, tais como: poliestireno expandido (isopor) e papelão, para verificar a qualidade e a viabilidade de comercialização do produto desenvolvido. 
$\left.6^{\circ}\right)$ Analisar o ciclo de vida das embalagens de fonte renovável produzidas por termoprensagem e por extrusão seguida de termoprensagem. 


\section{REVISÃO DA LITERATURA}

\subsection{Impactos ambientais das embalagens}

Grande quantidade de lixo plástico acumula-se dia após dia nos aterros sanitários, o que dificulta a circulação de líquidos e gases no solo e ainda retarda a estabilização da matéria orgânica. A geração de resíduos sólidos industriais no Brasil é cerca de 140 mil toneladas/dia, sendo que apenas metade recebe tratamento adequado. Quanto aos resíduos sólidos urbanos, a geração é de 100.000 toneladas/dia, sendo 60 a 70\% destinados aos lixões (Germer et al., 2002; Zanin e Mancini, 2004). Cerca de 1 milhão de sacos plásticos são despejados por minuto no planeta. Em São Paulo, estima-se que $18 \%$ do lixo são compostos desse material e cerca de $90 \%$ de todo o plástico produzido até hoje, no mundo inteiro, ainda não se decompôs (Revista da Folha de S.Paulo, 2007).

Devido ao grande volume de resíduos plásticos não renováveis, aos problemas associados à sua gestão, e ao longo período que levam para se degradar - muitos plásticos exigem mais de 100 anos para degradação total (Lee e Choi, 1998; Rosa et al., 2004) -, pesquisadores têm procurado por materiais renováveis e biodegradáveis capazes de substituir os polímeros à base de petróleo. As embalagens feitas de materiais biodegradáveis podem ser utilizadas para diminuir o impacto ambiental causado pelas embalagens convencionais.

\subsection{Fonte renovável: amido ou fécula}

O amido, reserva energética de plantas como o milho, arroz, mandioca, entre outras, é encontrado abundantemente na natureza graças ao cultivo extensivo e intensivo de cereais. É totalmente biodegradável, atóxico, renovável, tem custo relativamente baixo e é um importante segmento da economia (Da Róz, 2003). Segundo Tang et al. (2008a), o amido é atrativo por ser um material barato e por ter uma alta biodegradabilidade. $\mathrm{O}$ amido, armazenado nas células de frutos, sementes, raízes e tubérculos, está depositado na forma de grânulos mais ou menos brilhantes, apresentando formas e dimensões diversas (Silva et al., 2008); sua coloração é branca, é insípido, inodoro e forma uma suspensão 
leitosa quando em contato com água fria (Hoseney, 1999; Bobbio e Bobbio, 1995). Além de ser empregado nas indústrias de alimentos, cosméticos, produtos farmacêuticos, papel e têxtil, o amido tem sido utilizado também como um material termoplástico para aplicações em embalagens, tubetes para plantação, pratos e talheres.

O amido (FIG. 1) é uma mistura de dois polissacarídeos estruturalmente diferentes. Um dos componentes, a amilose, é uma molécula linear composta de 250 a 300 unidades de D-glicopiranose ligadas uniformemente por meio de pontes glicosídicas $\alpha-1,4$, conferindo forma helicoidal à molécula. $\mathrm{O}$ outro polissacarídeo é a amilopectina, constituída de unidades de glicose unidas por ligações $\alpha-1,4$. A maioria dos amidos tem proporções semelhantes de amilose e amilopectina: em média $25 \%$ de amilose e $75 \%$ de amilopectina. Segundo Steeneken e Woortman (2009), tais proporções dependem da origem botânica. A mandioca, por exemplo, é composta de 16,3\% de amilose, contra 25,6\% do milho (Debet e Gidley, 2006). Nas FIG. 1(a) e 1(b) estão apresentadas as estruturas da amilose e da amilopectina, respectivamente.

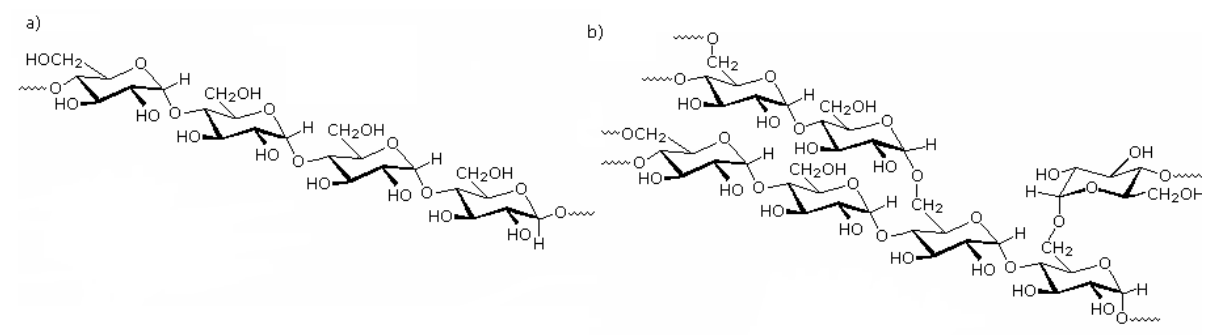

(a)

(b)

FIGURA 1 - Estrutura química da amilose (a) e da amilopectina (b).

A mandioca (Manihot esculenta crantz) é um dos vegetais mais cultivados no mundo, sendo o Brasil um dos principais países produtores (Butarelo et al., 2004). Em 2005, o país produziu 26,8 milhões de toneladas de mandioca numa área de 1,9 milhões de ha., e os principais produtores foram os estados do Pará, Bahia, Paraná, Maranhão e Rio Grande do Sul (Leonel et al., 2009). No mesmo ano, a produção de fécula de mandioca atingiu 546,5 mil toneladas, e o estado do Paraná foi o maior produtor (IBGE, 2007). A fécula é o constituinte mais abundante das raízes de mandioca, obtendo-se a partir dela o maior número de aplicações e subprodutos, sendo a produção de embalagens alimentícias um bom exemplo de sua utilização. 


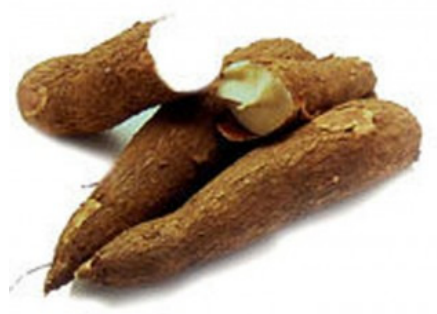

FIGURA 2 - Foto ilustrativa da mandioca (Manihot esculenta crantz). Fonte: EMBRAPA, 2009.

\subsection{Embalagens ativas de fonte renovável}

Alimentos frescos, seguros e convenientes são as exigências crescentes dos consumidores nos tempos modernos (Chen et al., 2009). Estudos mostraram que filmes e revestimentos comestíveis são ambientalmente corretos e que podem efetivamente promover a qualidade, durabilidade e praticidade de alimentos minimamente processados (Chien et al., 2007; Durango et al., 2006; Kristo et al., 2007; Parra et al., 2004).

Produtos minimamente processados podem ser definidos como frutas ou hortaliças, ou a combinação destas, que tenham sido fisicamente alteradas, mas que permaneçam em estado fresco. O processamento mínimo inclui as atividades de seleção e classificação da matéria-prima, pré-lavagem, processamento (corte, fatiamento), sanificação, enxágue, centrifugação e embalagem, visando-se obter um produto fresco e saudável e que, na maioria das vezes, não necessite subsequente preparo para ser consumido (Chitarra, 2000).

A especificação de sistemas de embalagem para frutos e hortaliças in natura ou minimamente processados é complexa, pois diferentemente de outros alimentos, estes produtos continuam respirando até mesmo depois de embalados. Além de proteção mecânica, as tecnologias envolvidas no desenvolvimento de embalagem para frutos e hortaliças visam reduzir a taxa de respiração e, consequentemente, aumentar a vida útil do produto (Sarantópoulos e Fernandes, 2001). Para atender às necessidades do mercado estão sendo desenvolvidas as chamadas embalagens ativas, definidas como embalagens que percebem mudanças no ambiente ao redor do produto e que respondem com alterações em suas propriedades (Yamashita, et al., 2006). As embalagens com ação antioxidante, de absorção de oxigênio, de odores e de umidade, e aquelas que liberam flavorizantes (Labuza e Breene, 1989; Sarantopoulos et al., 1996; Strathmann et al., 2005; Tovar et al., 2005) são alguns exemplos de embalagens ativas. No caso de embalagens ativas para frutos e 
hortaliças in natura, as principais ações preconizadas dizem respeito à absorção de etileno, um gás associado ao amadurecimento e à liberação de substâncias antimicrobianas, obtendo desta forma uma redução tanto na atividade fisiológica como no desenvolvimento microbiológico do alimento embalado (Yamashita et al., 2006).

No sentido convencional, uma embalagem aumenta a segurança do alimento de acordo com os seguintes mecanismos: barreiras a contaminações e prevenção de migração de seus próprios componentes para o alimento. Já os sistemas de embalagens ativas - que devem interagir de forma especificada (planejada) com o alimento - devem acumular funções adicionais, entre as quais podem ser destacadas: absorção de compostos que favoreça a deterioração, liberação de compostos que aumente a vida de prateleira, e monitoramento da vida de prateleira do produto (Azeredo et al., 2000).

As embalagens ativas são utilizadas para proporcionar informações sobre a qualidade do alimento embalado (a mudança de cor da embalagem, por exemplo, informa ao consumidor quão fresco está o alimento embalado) e para manter o frescor dos alimentos durante mais tempo. As primeiras patentes de embalagens ativas surgiram na década de 1980 no Japão e nos Estados Unidos. O conceito foi aplicado, inicialmente, na indústria farmacêutica, com os adesivos que liberam doses gradativas de medicamentos através da pele, como os repositores de hormônios, por exemplo. Em embalagens para alimentos destacam-se as pesquisas na Universidade de Cornell, EUA; Soares (1998), em seu doutorado realizado nessa universidade, desenvolveu um filme (plástico - não biodegradável) contendo a enzima naringinase, que diminui o sabor amargo do suco de grapefruit (toranja, em português) - fruta cítrica norte-americana. Para preservar ainda mais a qualidade dos sucos, leite, sopas e molhos, por longos períodos sem refrigeração, a empresa SIG Combibloc desenvolveu uma embalagem inteligente de alumínio para proteger o produto da luz e conservar seu aroma.

A embalagem ativa mais utilizada no mercado é a que controla o oxigênio (sachês com absorvedores de $\mathrm{O}_{2}$ ). É utilizada para verduras ensacadas, chamadas minimamente processadas, que precisam manter o frescor e a cor. No caso das embalagens inteligentes, no Brasil há uma marca de cerveja que apresenta no rótulo um indicador de sua temperatura.

Com base no exposto, considera-se de grande interesse promover industrialmente a obtenção de embalagens ativas de fontes renováveis. Diversos agentes ativos, como: ácido L-ascórbico (absorvedor de $\mathrm{O}_{2}$ - agente que evita o escurecimento enzimático), sorbato de potássio (conservante - evita a proliferação de fungos), cloreto de cálcio (evita a perda de peso), permanganato de potássio (controla os níveis de etileno, de modo a aumentar o 
tempo de vida de um alimento embalado) e extratos de vegetais como indicadores de $\mathrm{pH}$ (monitoram a qualidade do produto embalado) foram incorporados à massa (fécula de mandioca, aditivos e água) para a produção de embalagens ativas, tipo espuma, utilizadas para acondicionar frutas minimamente processadas.

\subsubsection{Produção das embalagens ativas}

Diferentes métodos são utilizados para processar amido em materiais de embalagem: extrusão, injeção e termoprensagem (Hofmann, 1998). Os estudos mostraram que é possível a obtenção de embalagens para alimentos a partir de amido por processos como filtração a vácuo (Matsui et al., 2004), extrusão (Cinelli et al., 2006) ou termoprensagem (Shey et al., 2006; Soykeabkaew et al., 2004; Salgado et al., 2008), que podem substituir as espumas de poliestireno expandido. As espumas de fécula de mandioca deste projeto foram desenvolvidas por extrusão e termoprensagem.

O processamento do amido é complexo e de difícil controle em relação ao de polímeros convencionais devido às suas propriedades de processamento insatisfatórias, resultado de sua alta viscosidade, evaporação da água, rápida retrogradação, etc. (Liu et al., 2009). Entretanto, estima-se que, com o desenvolvimento de formulações e condições de processamento adequados, muitos desses desafios poderão ser superados.

A extrusão é a técnica mais utilizada para o processamento de polímeros à base de amido, e suas vantagens incluem: a capacidade de lidar com polímeros de alta viscosidade na ausência de solventes, grande flexibilidade operacional devido à ampla gama de condições de processamento, a viabilidade de injeções múltiplas, e controle de "tempo de residência" e grau de mistura (Van Duin et al., 2001). Outras técnicas de processamento, tais como injeção e termoprensagem, são frequentemente combinadas à extrusão. Chen et al. (2004), utilizaram uma "panela" de pressão atmosférica para submeter as espumas de amido-acetato-fibras ao processo de vaporização, após a extrusão.

Existem dois tipos de extrusora: a mono rosca e a dupla rosca. Uma extrusora consiste essencialmente de um cilindro e um parafuso (rosca) que gira em seu interior como mostra a FIG. 3. O movimento do parafuso promove o transporte do material preenchendo os vazios entre os filetes. Durante esse processo o material é progressivamente aquecido, plastificado, comprimido e, finalmente, forçado através do orifício de uma matriz existente na extremidade do cilindro. Além das funções específicas, o parafuso afeta as condições gerais de extrusão em conjunto com outros parâmetros (Blass, 1985). 


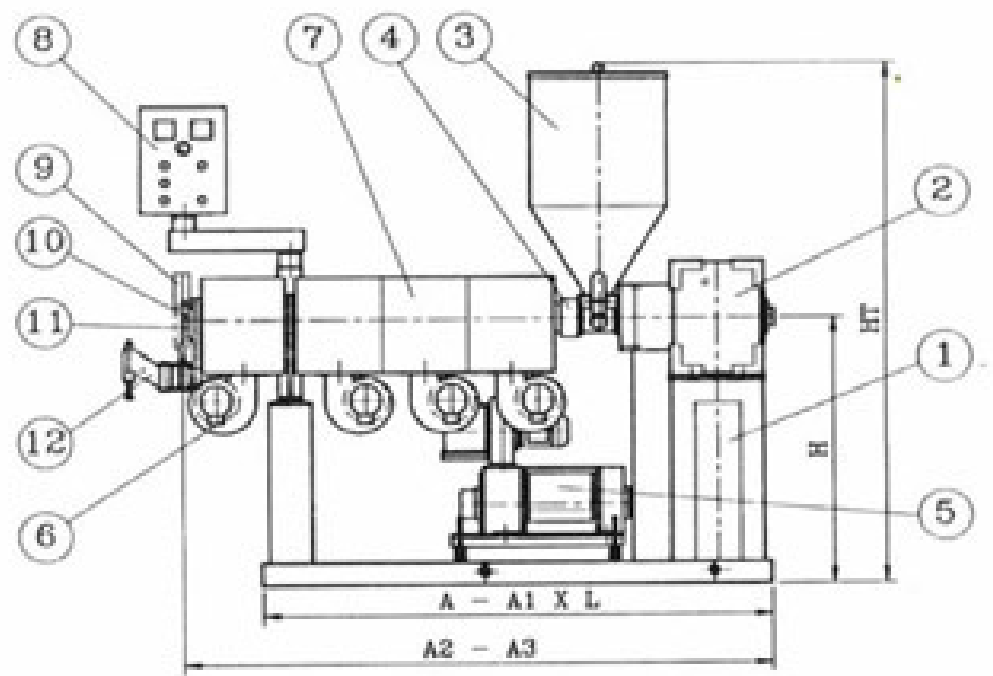

1: Base

2: Redutor

3: Funil

4: Anel de resfriamento

5: Motor

6: Ventiladores

7: Proteção das residências

8: Painel de comando

9: Fecho bi-partido

10: Cilindro

11: Parafuso (rosca)

12: Suporte para cabeçote

FIGURA 3 - Desenho esquemático de uma extrusora mono rosca. Fonte: Pickler Máquinas e Equipamentos Ltda., 2010.

Dentre todos os componentes de uma extrusora, a rosca (parafuso) é um dos mais importantes por transportar, fundir (ou amolecer), homogeneizar e plastificar o polímero. É devido ao movimento, e consequente cisalhamento do material, que a rosca única gera cerca de $80 \%$ da energia (térmica e mecânica) necessária para transformar os polímeros. Outra parte da energia térmica é obtida por meio de aquecedores externos (Blass, 1985).

No processo de termoprensagem, a mistura (fécula de mandioca, água e aditivos) é colocada na parte de baixo de um molde aquecido por resistências elétricas instaladas no interior do equipamento (termoprensa). Em seguida, a parte superior abaixa, de modo a espalhar a massa sobre a superfície do molde. A FIG. 4 mostra os princípios básicos do processo.

A: Abertura do molde

B: Fechamento do molde 1: Parte superior do molde aquecida

2: Parte inferior do molde aquecida

3: Massa (suspensão da fécula em água e aditivos)

4: Formação da espuma

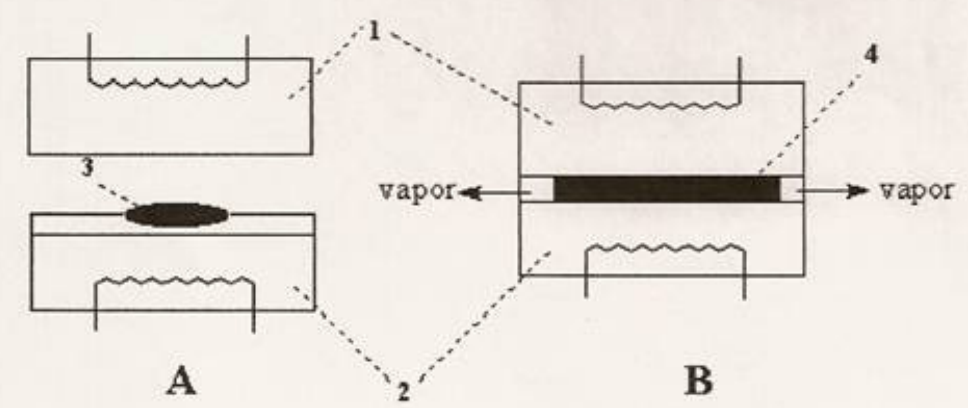

FIGURA 4 - Desenho esquemático da termoprensagem. Fonte: Hofmann et al., 1998. 
Com o aquecimento, a água da mistura começa a evaporar e os grânulos da fécula se expandem e gelatinizam - processo de transformação do amido granular em pasta viscoelástica. $\mathrm{O}$ vapor causa a expansão da massa e todo o molde é preenchido, levando à solidificação do material e consequente obtenção da espuma que, em seguida, pode ser removida, ainda quente, da máquina. Pratos, copos, bandejas, etc., podem ser produzidos dependendo do tipo de molde utilizado (Souza e Andrade, 2000; Ragheb et al., 1996; Beleia et al., 1996).

As embalagens feitas de espumas de fécula de mandioca têm boas propriedades mecânicas e um preço competitivo no mercado, além de serem totalmente biodegradáveis - levam cerca de 20 dias para se degradar sem deixar resíduos. Contudo, a natureza hidrofílica do amido, isto é, sua elevada afinidade com água, é um dos principais entraves que limita seriamente o desenvolvimento de materiais à base desse carboidrato (López et al., 2008; Glenn et al., 2001). Para melhorar as propriedades mecânicas e de barreira, pesquisadores têm estudado a produção destes materiais a partir de amidos processados ou modificados (química, física ou biologicamente), com ou sem a adição de plastificantes, fibras, polímeros, cargas minerais e outros aditivos. Além disso, vários métodos físicos vêm sendo estudados como a aplicação de radiação ionizante (Nemtanu et al., 2007) e radiação gama (Kim et al., 2008), extrusão do amido (Chaudhary et al., 2008; Willett e Shogren, 2002), etc. O aumento do teor de amilose e da concentração de amido produz espumas mais densas e fortes; no entanto, espumas mais densas têm menor flexibilidade (Shogren et al., 1998). Zhai et al. (2003) investigaram a influência de plastificantes (glicerol, etilenoglicol e polietilenoglicol) sobre as propriedades de filmes à base de amido e mostraram que o glicerol foi um excelente plastificante, de modo que a ductilidade de filmes de amido foi melhorada significativamente (aumento do alongamento na ruptura). Nas indústrias, diversos tipos de amidos modificados têm sido desenvolvidos para controlar a solubilidade em água, inchaço, viscosidade, poder de adesividade e reatividade (Henry et al., 2009).

\subsubsection{Por irradiação}

Radiações ionizantes (gama ou elétrons), aplicadas há muito tempo em um grande número de polímeros, especialmente para reticulação (Chapiro, 1988; Erlandsson et al., 1997), são agora frequentemente usadas no tratamento de amidos (Henry et al., 2009). A irradiação gama é uma ferramenta muito conveniente para a modificação de materiais 
poliméricos por meio de técnicas de reticulação, enxertia e degradação (Lacroix et al., 2002; Ressouany et al., 1998).

Quando exposto à radiação gama, o amido sofre interessantes mudanças nas suas propriedades físico-químicas (Ghali et al., 1979; Raffi et al., 1981a-c; Korotchenko et al., 1982; Hayashi e Aoki, 1985; Ciesla e Eliasson, 2002). A radiação gama promove a redução da massa molar do amido à metade após ser irradiado a doses próximas a 20 kGy (Ghali et al., 1979; Raffi et al., 1980, 1981a-c; Korotchenko et al., 1982). Foi mostrado que ligações químicas de amido podem ser hidrolisadas pela irradiação gama levando à degradação da cadeia polimérica (Kong et al., 2009). Segundo Ciesla e Eliasson (2002), o índice de degradação aumenta proporcionalmente à dose, isso como consequência das cisões na cadeia principal do amido induzida pela radiação gama. Resultados semelhantes foram obtidos por Oliveira et al. (2006). Os autores estudaram o efeito do poliéster biodegradável, poli(hidroxibutirato), PHB, quando exposto à radiação gama e observaram, como resultado, a redução da massa viscosimétrica do filme de PHB à metade; observaram também que o índice de degradação aumentou proporcionalmente à dose, estabilizando-se acima de $25 \mathrm{kGy}$.

\subsubsection{Com aditivos}

Os aditivos são substâncias adicionadas aos polímeros em pequenas quantidades para: (a) alterar a propriedade do material; (b) conferir estabilidade ao material durante o processamento. De um modo geral, os aditivos devem ser eficientes em sua função, estáveis nas condições de processamento, ter fácil dispersão, serem atóxicos e de baixo custo (Rabello, 2000).

Os materiais obtidos a partir de amido são quebradiços e sensíveis ao contato direto com água. Requerem o uso de tratamentos especiais (modificações física e química) com ou sem aditivos, como: plastificantes e cargas minerais, para melhorar sua resistência à tração, flexibilidade e resistência ao contato com a água, ao óleo e à gordura (Andersen e Hodson, 2001; Andersen et al., 2001; Shogren et al., 2002; Soykeabkaew et al., 2004).

\subsection{Plastificantes}

Os plastificantes são aditivos muito empregados em materiais poliméricos para melhorar a processabilidade e aumentar a flexibilidade. Segundo, Chen e Lai (2008), a incorporação de uma quantidade apropriada de plastificante pode melhorar a flexibilidade de filmes com justas propriedades de barreira à água. Em termos práticos, a plastificação 
de um polímero consiste em adicionar os plastificantes para alterar a viscosidade do sistema, aumentando a mobilidade das macromoléculas (Rabello, 2000).

O amido é um polímero com três grupos hidroxilas por monômero, com diversas ligações de hidrogênio inter e intramoleculares. Quando o plastificante forma ligações de hidrogênio com o amido, as ligações de hidrogênio originais dos grupos hidroxilas da molécula de amido são destruídas, produzindo a plastificação (Ma et al., 2005).

Tang et al. (2008b) produziram nanocompósitos de amido e argila pelo processo de extrusão, usando glicerol como plastificante. Seus resultados indicaram que as interações da matriz de amido com a superfície de argila foram cruciais para a formação da nanoestrutura. Pelo fato dos plastificantes exercerem um papel indispensável no processo de formação de amido termoplástico, devido às interações entre amido e plastificantes, supôs-se que os plastificantes também possam participar de interações entre amido e argila, e daí poder afetar fortemente a formação da nanoestrutura e, consequentemente, influenciar as propriedades mecânicas de filmes nanocompósitos de amido-argila (Tang et al., 2008b). Parra et al. (2004), produziram filmes comestíveis de fécula de mandioca e estudaram os efeitos dos plastificantes glicerol e polietilenoglicol nas suas propriedades mecânicas e de transmissão de vapor d'água. Tais filmes apresentaram boa flexibilidade e baixa permeabilidade à água, indicando potencial aplicação dos plastificantes nos filmes.

Neste trabalho foram utilizados o glicerol e o polietilenoglicol (PEG 300) como plastificantes.

\subsubsection{Avaliação do Ciclo de Vida (ACV)}

A Avaliação (ou Análise) do Ciclo de Vida é uma ferramenta que permite avaliar os aspectos ambientais e os impactos potenciais associados ao ciclo de vida de um produto, ou seja, desde a extração dos recursos naturais no sistema produtivo, passando por todas as operações industriais e de consumo, até à disposição final do produto. A FIG. 5 mostra as etapas consideradas em um estudo de ACV. As categorias gerais de impacto ambiental consideradas em estudos de ACV incluem uso de recursos naturais, implicações sobre a saúde humana e consequências ecológicas (Mattsson e Sonesson, 2003). 


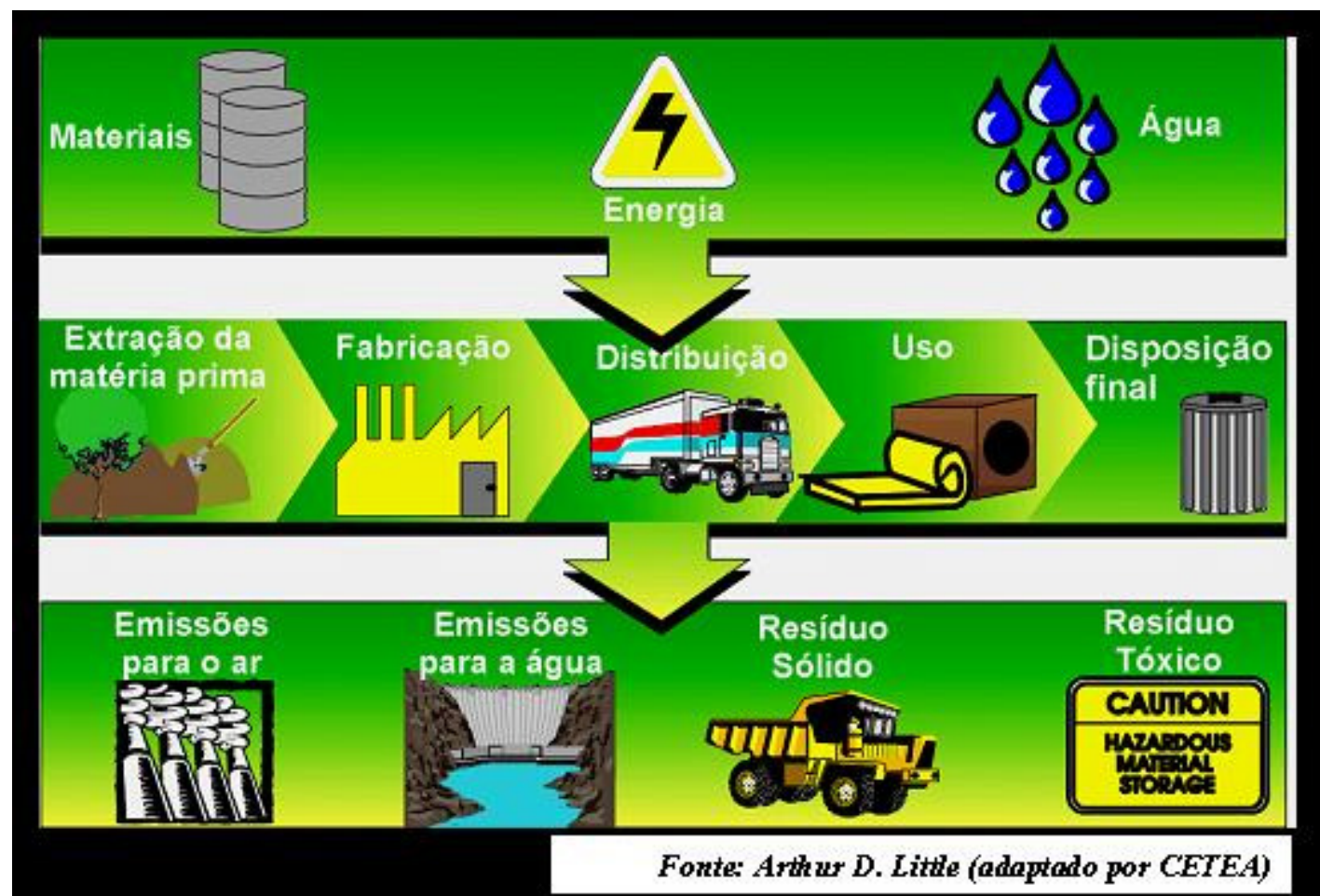

FIGURA 5 - Representação das etapas consideradas em um estudo de ACV.

Para a descrição dos sistemas se faz necessária a realização de balanços de massa e energia para se determinar a geração de emissões gasosas, efluentes líquidos e resíduos sólidos (Valt, 2004).

Empregando a ACV é possível avaliar a implementação de melhorias ou alternativas para produtos, processos ou serviços. Declarações ambientais sobre o produto podem se basear em estudos de ACV, bem como a integração de aspectos ambientais no projeto e desenvolvimento de produtos (Coltro, 2007).

Neste trabalho foi feito um breve estudo de ACV das embalagens de fécula de mandioca obtidas por dois processos: (a) termoprensagem e (b) extrusão seguida de termoprensagem.

A industrialização e o uso de embalagens adequadas possibilitam a redução da perda de alimentos, o aproveitamento de subprodutos industriais e o aumento da segurança alimentar (Mourad, 2002).

A embalagem é essencial para a indústria e para o comércio, sendo fundamental para a logística de distribuição dos produtos desde os centros de produção até o consumo. Entretanto, é inegável que, após seu uso, ainda há um valor agregado à embalagem, seja pelo material que pode vir a ser aproveitado ou pela energia que ainda está disponível nesse resíduo (Mourad, 2002). 


\subsubsection{Biodegradação}

Biodegradação é um processo que consiste na modificação física ou química, causada pela ação de microorganismos, sob certas condições de calor, umidade, luz, oxigênio e nutrientes orgânicos e minerais adequados (Amass et al., 1998). Segundo Flemming (1998), que não utiliza o termo biodegradação e sim, biodeterioração de materiais poliméricos, esta é causada por microorganismos que colonizam sua superfície, formando biofilmes, que consistem de microorganismos embebidos em uma matriz de biopolímeros excretados por eles que, em contato com os polímeros, causam mudanças estruturais e/ou morfológicas. A biodegradação pode ser facilitada por aplicação de processos prévios de luz (UV) e/ou calor na matriz polimérica (Xu e Guo, 1995). A presença de ligações hidrolisáveis ou oxidáveis na cadeia, uma estereoconfiguração correta, um balanço entre hidrofobicidade e hidrofilicidade e uma certa flexibilidade conformacional são fatores que contribuem para a biodegradação do polímero (Huang e Edelman, 1995). Por depender de vários fatores, os testes de biodegradabilidade são de difícil padronização (Paci e La Mantia, 1999).

Uma maneira de diminuir a quantidade de resíduos plásticos resistentes à degradação natural no meio ambiente, é o emprego de polímeros biodegradáveis naturais, tais como as embalagens feitas de amido desenvolvidas neste trabalho. O amido pode ser transformado em materiais de espuma - bandejas ou pratos descartáveis, por exemplo -, substituindo as embalagens de espuma de poliestireno expandido (isopor). As embalagens de amido se dissolvem na água, liberando uma solução não tóxica, e são consumidas pelo ambiente microbiano em aproximadamente 10 dias, dando apenas água e dióxido de carbono $\left(\mathrm{CO}_{2}\right)$ como subprodutos (Siracusa et al., 2008). 


\section{METODOLOGIA}

\subsection{Materiais}

- Fécula de mandioca em pó fornecida pela Flor de Lotus Inc. (Bahia);

- Fécula de mandioca em pó fornecida pela Companhia Lorenz (Quatro Pontes, PR);

- Fécula de mandioca modificada quimicamente por acetilação (em pó) fornecida pela Companhia Lorenz (Quatro Pontes, PR);

- Polietilenoglicol (PEG 300) fornecido pela Oxiteno (São Paulo);

- Glicerol $\left(\mathrm{C}_{3} \mathrm{H}_{8} \mathrm{O}_{3}\right)$ - contendo como máximo de impurezas: 0,003\% de compostos clorados; $0,05 \%$ de ésteres de ácidos graxos; 2 ppm de metais pesados (como $\mathrm{Pb}$ ); 0,005\% de resíduo após ignição e $0,001 \%$ de sulfatos $\left(\mathrm{SO}_{4}\right)$ - fornecido pela distribuidora Labsynth Produtos para Laboratórios (São Paulo, SP);

- Sorbato de Potássio $\left(\mathrm{C}_{6} \mathrm{H}_{7} \mathrm{KO}_{2}\right)$ fornecido pela Vetec Química Fina Ltda (Duque de Caxias, RJ);

- Permanganato de Potássio $\left(\mathrm{KMnO}_{4}\right)$, Cloreto de Cálcio $\left(\mathrm{CaCl}_{2}\right)$, Ácido L-Ascórbico $\left(\mathrm{C}_{6} \mathrm{H}_{8} \mathrm{O}_{6}\right)$, Ácido Clorídrico $(\mathrm{HCl})$ e Hidróxido de Sódio $(\mathrm{NaOH})$ fornecidos pela distribuidora Labsynth Produtos para Laboratórios (São Paulo, SP);

- Corantes naturais: beterraba e repolho roxo, adquiridos, in natura, em supermercado;

- Embalagem convencional de isopor (poliestireno expandido) adquirida em supermercado.

\subsection{Métodos}

\subsubsection{Produção das embalagens de fécula de mandioca tipo espuma}

As espumas de fécula de mandioca foram obtidas por:

a) termoprensagem;

b) extrusão seguida de termoprensagem (processo utilizado somente com as formulações contendo os agentes ativos);

Os dois métodos partem de uma mistura de fécula de mandioca, gel (composto por fécula de mandioca dispersa em água) e aditivos. 
Preparação do gel: em uma panela, a fécula de mandioca foi dispersa em água (10:100) e aquecida por 45 minutos em uma chapa a $80^{\circ} \mathrm{C}$. Durante o aquecimento o sistema foi constantemente agitado até a completa gelatinização da fécula (Bobbio e Bobbio, 1984).

Em seguida, essa dispersão foi resfriada até a temperatura ambiente, recebendo em seguida adições de mais fécula e de aditivo. A massa obtida foi homogeneizada por cerca de três minutos por um misturador de laboratório com capacidade para dois quilos de massa; ou, em alguns casos, por outro misturador de laboratório com capacidade para cinco quilos de massa, como mostra a FIG. 6.

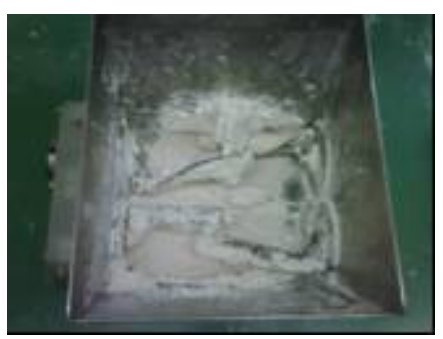

(a)

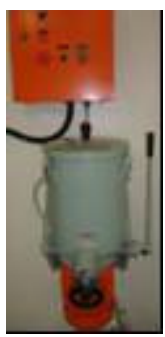

(b)

FIGURA 6 - Fotografias dos misturadores de laboratório com capacidade para dois (a) e cinco (b) quilos de massa.

Após a homogeneização da massa as espumas foram então obtidas pelos processos já citados. A extrusão da massa foi realizada na Compacta Print Ltda. por meio de uma extrusora mono rosca (Extrusora Compacta SR2008/35 - cilindro de $950 \mathrm{~cm}$ de comprimento e $50 \mathrm{~cm}$ de diâmetro) equipada com três zonas de aquecimento, cujas temperaturas foram mantidas a 90,120 e $130^{\circ} \mathrm{C}$, da zona de alimentação à saída da matriz. A rotação da rosca foi fixada em 43,7 rpm para todas as formulações estudadas.
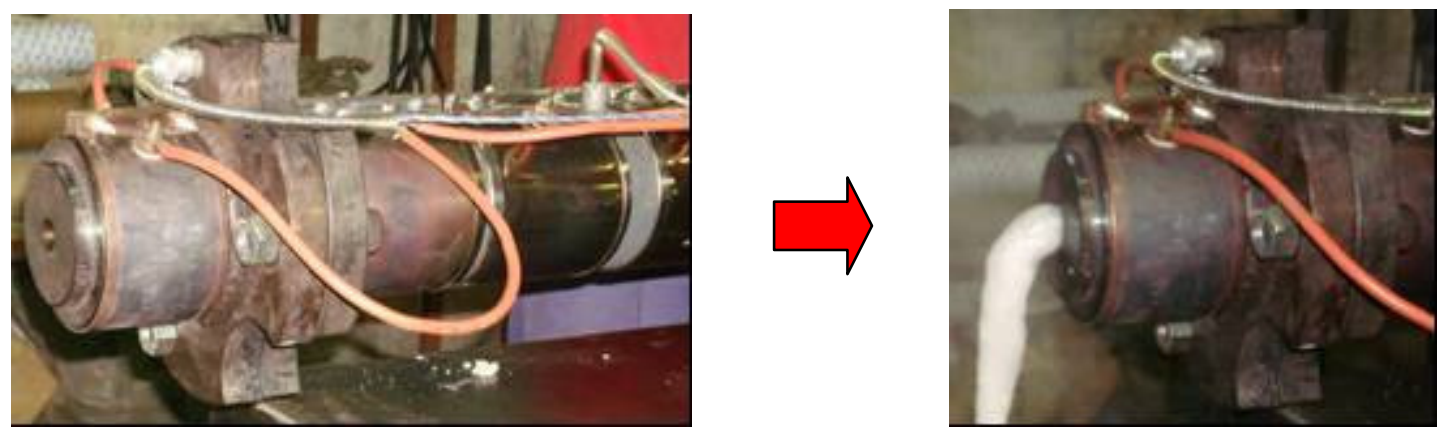

FIGURA 7 - Extrusão da massa em extrusora mono rosca equipada com três zonas de aquecimento. 
Depois de extrusada, quantidades de massa foram termoprensadas, uma a uma, à temperatura de $190^{\circ} \mathrm{C}$ e pressão de 1 bar, obtendo-se as espumas de fécula de mandioca. A termoprensagem foi feita na Compacta Print Ltda. em forma de potes (FIG. 8) e, em laboratório, na forma de placas retangulares (FIG. 9).

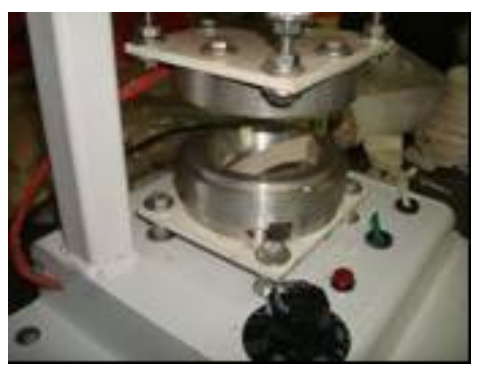

alimentação

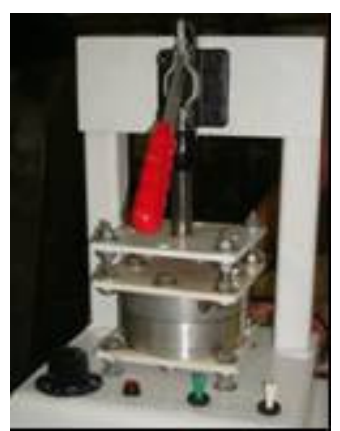

termoprensagem

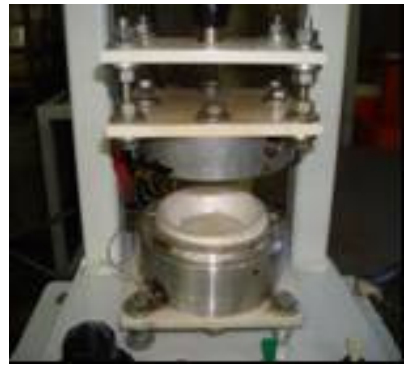

obtenção da espuma

FIGURA 8 - Produção das espumas de fécula de mandioca por termoprensagem, em forma de potes.

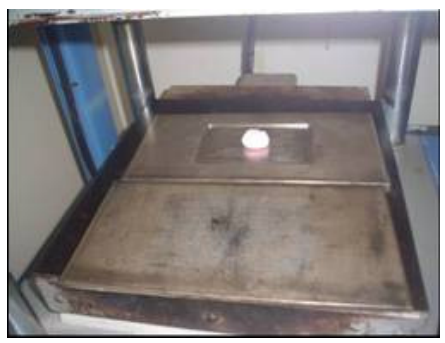

alimentação

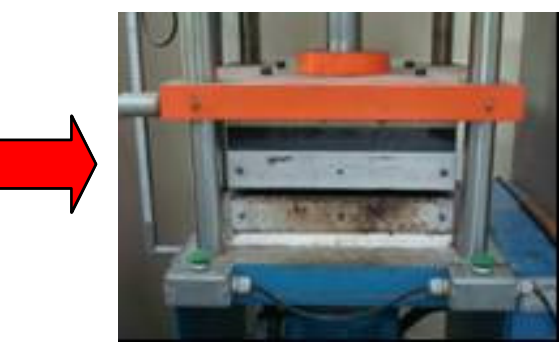

termoprensagem

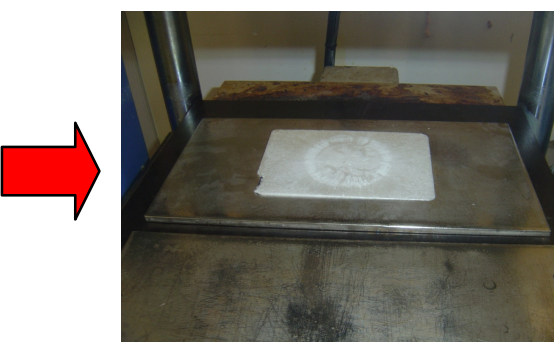

obtenção da espuma

FIGURA 9 - Produção das espumas de fécula de mandioca por termoprensagem, em forma de placas retangulares.

\subsubsection{Adição de plastificantes à massa}

Plastificantes como glicerol e polietilenoglicol (PEG 300) foram utilizados em diferentes formulações, sendo adicionados à massa (mistura de fécula de mandioca e gel) em diferentes concentrações ( $1 \%, 2 \%$ e $5 \%$ em peso dos sólidos). Nenhuma formulação utilizou simultaneamente os dois plastificantes.

O plastificante foi diretamente adicionado à mistura de fécula de mandioca e gel no misturador, antes da extrusão e termoprensagem. Para efeito de comparação, foram produzidas espumas (embalagens) de fécula de mandioca sem glicerol ou PEG 300. 


\subsubsection{Concentrações de sólido (fécula de mandioca em pó)}

As espumas (embalagens) foram produzidas em concentrações de $55 \%$ e $57 \%$ de fécula de mandioca em pó para $2 \%$ em peso de plastificante. A fécula de mandioca (em ambas as concentrações - 55 e 57\%) e o respectivo plastificante foram adicionados ao gel no misturador de laboratório.

\subsubsection{Tratamentos da fécula de mandioca}

Assim como as diferentes concentrações de fécula e os diferentes tipos e concentrações de plastificantes nas formulações, foram estudados diversos tratamentos (químicos e físicos) dados à fécula de mandioca para verificar, principalmente, sua influência sobre a estabilidade de produção e propriedades mecânicas e de barreira das espumas (embalagens). Para a produção das embalagens preparamos formulações utilizando fécula de mandioca modificada quimicamente (acetilação) e fécula prégelatinizada e irradiada por radiação gama (modificações físicas). Estudou-se ainda a influência nas propriedades mecânicas e de barreira e o aspecto visual das espumas produzidas por féculas de dois diferentes estados brasileiros (Bahia e Paraná).

\subsection{Modificação química da fécula}

A fécula de mandioca foi modificada quimicamente por acetilação e fornecida pela Companhia Lorenz. Foram utilizados $10 \%$ em massa de fécula modificada e $47 \%$ em massa de fécula de mandioca sem modificação - totalizando $57 \%$ de fécula de mandioca em pó - despejados no misturador de laboratório juntamente com o gel (fécula de mandioca normal - sem modificação - e água) e o plastificante polietilenoglicol (PEG 300 - $2 \%$ em massa dos sólidos). A mistura foi homogeneizada por 3 minutos, antes da termoprensagem.

\subsection{Modificações físicas da fécula}

\subsection{Pré-gelatinização da fécula}

A mistura de fécula de mandioca e água $(10: 100 \mathrm{~m} / \mathrm{m})$ foi aquecida a uma temperatura de $80^{\circ} \mathrm{C}$ por meio de uma chapa, durante 45 minutos e com constante agitação, até a formação de gel. $\mathrm{O}$ gel foi seco em estufa a $100^{\circ} \mathrm{C}$ por cerca de um dia. Em seguida, o gel seco foi colocado em um liquidificador até obtenção do pó. Cerca de $10 \%$ em massa de amido pré-gelatinizado e seco (gel seco em pó) e $47 \%$ em massa de fécula de 
mandioca - totalizando $57 \%$ de fécula de mandioca em pó - foram adicionados ao gel (fécula de mandioca e água) e ao plastificante polietilenoglicol (PEG 300 - 2\% em peso). A mistura foi homogeneizada por cerca de três minutos com auxílio de um misturador de laboratório. Em seguida, foi feita a extrusão e a termoprensagem.

\subsection{Irradiação da fécula}

A fécula de mandioca em pó foi armazenada em sacos plásticos, que por sua vez foram armazenados em caixas de papelão, e encaminhadas à Empresa Brasileira de Radiações (EMBRARAD). A irradiação da fécula em pó (antes do processo de termoprensagem) foi realizada com raios gama provenientes de uma fonte de ${ }^{60} \mathrm{Co}$ (cobalto-60), à temperatura ambiente, nas doses de 3, 6, 12 e 25 kGy. A taxa de dose utilizada foi de $5,0 \mathrm{kGy} / \mathrm{h}$.

Espumas (embalagens) foram produzidas com $10 \%$ e $100 \%$ de fécula de mandioca irradiada. As primeiras foram despejadas no misturador de laboratório juntamente com 47\% de fécula de mandioca normal (sem modificação), gel e plastificante PEG 300 (2\% em peso dos sólidos), enquanto aquelas com $100 \%$ de fécula irradiada foram despejadas no misturador juntamente com o gel e o plastificante, sem adição de fécula de mandioca normal.

\subsubsection{Outro fornecedor de fécula}

$\mathrm{Na}$ produção das espumas utilizamos fécula de mandioca de dois diferentes estados brasileiros: Bahia e Paraná. Para estes estudos, a fécula de mandioca em pó foi adicionada ao gel (fécula de mandioca suspensa em água) e ao plastificante PEG 300 (2\% em peso dos sólidos) no misturador de laboratório (antes, é claro, dos processos de termoprensagem e extrusão).

\subsubsection{Reaproveitamento das espumas}

As espumas produzidas pelo processo de termoprensagem foram trituradas/moídas até obtenção do pó, e utilizadas como matéria-prima na fabricação de novos produtos espumados/novas embalagens. Cerca de $10 \%$ do pó das espumas trituradas foram transferidos ao misturador de laboratório juntamente com $47 \%$ em massa dos sólidos de fécula de mandioca normal (sem modificação) - totalizando $57 \%$ de fécula de mandioca em pó -, gel e plastificante PEG 300 (2\% em peso), antes da termoprensagem. 


\subsubsection{Estudo da Avaliação do Ciclo de Vida (ACV)}

Um estudo de ACV inicia-se com a definição do objetivo do estudo, bem como são definidos nessa fase a unidade funcional adotada, as fronteiras do sistema, as estimativas e limitações e os métodos de alocação que serão usados, bem como as categorias de impacto que serão consideradas no estudo. O objetivo inclue a definição do contexto do estudo ao qual estão associados, a quem e como os resultados serão comunicados. A unidade funcional é a unidade de referência quantitativa à qual todos os fluxos de entradas e saídas na ACV estão relacionados - por exemplo, $1 \mathrm{Kg}$ de café torrado e moído pronto para a distribuição. A alocação é o método utilizado para dividir a carga ambiental de um processo entre os diversos produtos nele gerados (co-produtos) (Coltro, 2007).

$\mathrm{Na}$ fase de Análise de Inventário é elaborado um fluxograma do sistema em estudo e, em seguida, faz-se um levantamento de dados de entradas e saídas (consumo de recursos naturais e energia, emissões para o ar, água e solo) para todas as etapas incluídas nas fronteiras do estudo de ACV. Estes dados são compilados e as cargas ambientais do sistema são calculadas e relacionadas à unidade funcional (Coltro, 2007).

E, finalmente, na fase de Avaliação de Impacto do Ciclo de Vida os dados são interpretados em termos de seus impactos ambientais (mudanças climáticas - aquecimento global -, acidificação, eutrofização, etc.).

Devido à complexidade deste projeto, não foi possível realizar todas as etapas de um estudo de $\mathrm{ACV}$ - os métodos de alocação e as categorias de impacto, por exemplo, não foram considerados neste estudo.

\subsubsection{Produção das embalagens ativas de fécula de mandioca tipo espuma}

\subsection{Adição de agentes ativos à massa}

Agentes ativos como permanganato de potássio, sorbato de potássio, cloreto de cálcio e ácido l-ascórbico foram utilizados, individualmente, em diferentes formulações. Eles foram adicionados à massa (mistura de 57\% de fécula de mandioca em pó, gel e 2\% de plastificante PEG 300), em diferentes concentrações (5\%, 10\% e 15\% em massa dos sólidos). Tal adição foi feita de duas formas: (1) sem a incorporação do ativo no gel: cada agente ativo foi, primeiramente, misturado à fécula de mandioca em pó. Em seguida, essa mistura foi adicionada ao gel e ao plastificante no misturador e (2) com a incorporação do ativo no gel: cada agente ativo foi, primeiramente, misturado ao gel e ao plastificante e em seguida à fécula de mandioca em pó no misturador. 


\subsection{Adição de corantes naturais à massa}

Os corantes naturais de beterraba e repolho roxo, nas concentrações de 5\%, $10 \%$ e $15 \%$ em massa dos sólidos, foram adicionados, individualmente, em diferentes formulações. Eles foram misturados ao gel contendo 2\% de plastificante PEG 300 (incorporação do corante no gel) para posterior mistura com a fécula de mandioca em pó (57\%) no misturador. Tais corantes, como era de se esperar, apresentaram diferença de coloração em função do pH, ou seja, nos meios ácido, básico e neutro.

\subsection{Extração dos pigmentos naturais}

$\mathrm{Na}$ extração dos pigmentos, os legumes (beterraba e repolho roxo), adquiridos in natura, foram descascados, cortados em pequenos pedaços e triturados em liquidificador. À massa triturada (cerca de 25g), como mostra a FIG. 10, foram adicionados $50 \mathrm{~mL}$ de água destilada, misturando-se bem essa solução e deixando-a em repouso por 15 minutos para a extração dos corantes. Em seguida, a solução foi filtrada com papel filtro no funil, como mostra a FIG. 11. Este procedimento foi repetido para cada legume (beterraba e repolho roxo), sempre com o uso de água destilada.

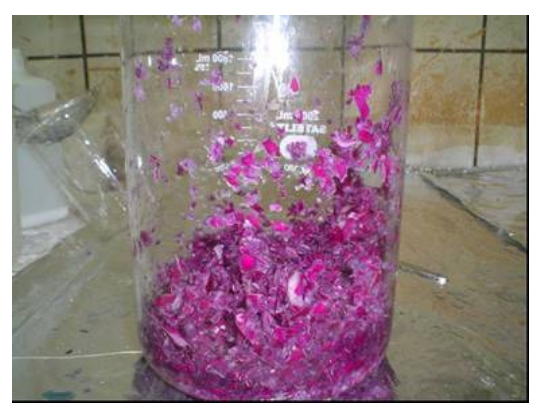

FIGURA 10 - Repolho roxo obtido após trituração. 


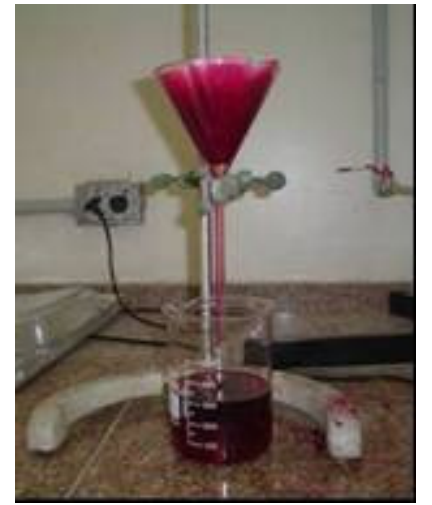

FIGURA 11 - Aparato para extração do pigmento natural de repolho roxo.

Para testar o pigmento natural como indicador de $\mathrm{pH}$, cerca de $5 \mathrm{~mL}$ do extrato filtrado foram adicionados em cada um dos três tubos de ensaio. No primeiro não se adicionou reagente, no segundo adicionou-se $1 \mathrm{~mL}$ de solução aquosa de $\mathrm{NaOH}(5 \%$, v/v) e no terceiro $1 \mathrm{~mL}$ de solução aquosa de $\mathrm{HCl}(5 \%, \mathrm{v} / \mathrm{v})$.

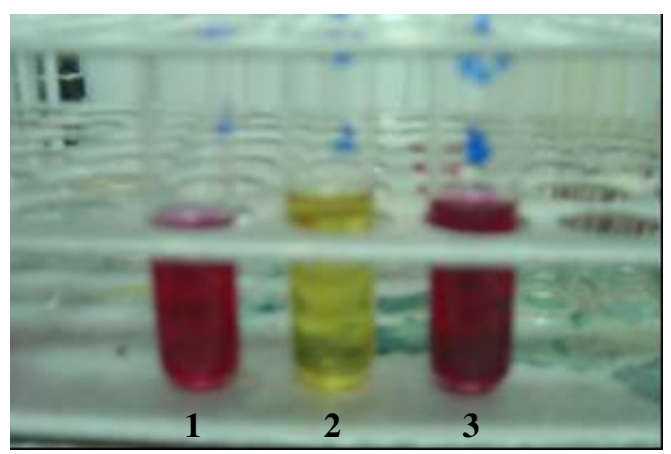

(a)

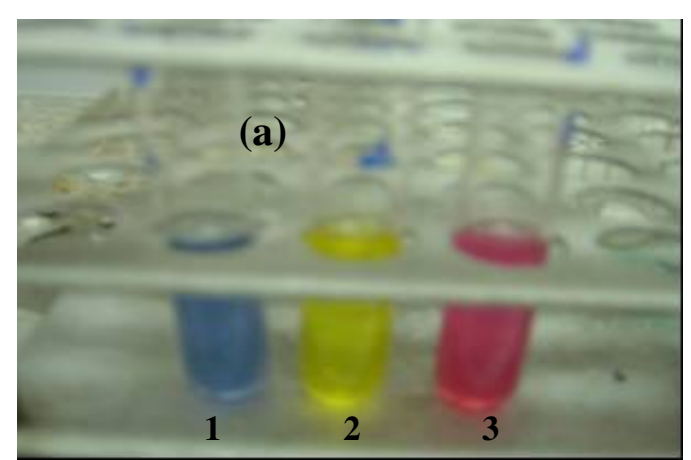

(b)

FIGURA 12 - Fotografias da coloração obtida dos extratos de (a) beterraba e (b) repolho roxo em função do $\mathrm{pH}$.

Na TAB. 1 (a seguir) está apresentada a coloração dos extratos naturais da beterraba e do repolho roxo em água destilada nos meios neutro, básico e ácido. 
TABELA 1 - Coloração dos pigmentos da beterraba e do repolho roxo em água destilada, em função do $\mathrm{pH}$.

\begin{tabular}{|c|c|c|c|}
\hline \multirow{2}{*}{ EXTRATO } & $\begin{array}{c}\text { MEIO NEUTRO } \\
(\mathbf{1})\end{array}$ & $\begin{array}{c}\text { MEIO BÁSICO } \\
\mathbf{( 2 )}\end{array}$ & $\begin{array}{c}\text { MEIO ÁCIDO } \\
\mathbf{( 3 )}\end{array}$ \\
\hline Beterraba & vermelha & amarela & vinho (claro) \\
\hline Repolho roxo & lilás & amarela & rosa \\
\hline
\end{tabular}

\subsubsection{Quantidade de massa para formar uma embalagem}

Cada formulação de embalagens (espumas) foi produzida num período de quase duas horas, sendo que durante a produção uma quantidade mínima de massa foi adicionada dentro do molde, de modo a preenchê-lo totalmente e formar uma espuma completa sem falhas (bolhas e rachaduras). Essa quantidade de massa foi calculada com base na média das quantidades de massa utilizadas para formar as espumas produzidas nesse período.

\subsubsection{Perda de produção das espumas}

A perda de produção das embalagens (espumas) de fécula de mandioca de diferentes formulações (produzidas em laboratório) foi calculada no processo de termoprensagem com base na quantidade total de embalagens obtidas e na quantidade de embalagens formadas com bolhas e/ou rachaduras, num período de duas horas. Assim, para a produção de cada formulação, fez-se o seguinte cálculo:

$\%$ de perda de produção $=\underline{\text { espumas com defeito }} \times 100$

total de espumas

\subsubsection{Densidade das espumas}

A análise de densidade consistiu na medida direta da massa da embalagem (espuma) dividida pelo seu volume, obtendo-se o resultado em $\mathrm{g} / \mathrm{cm}^{3}$. Foram analisadas cinco amostras de cada formulação, sendo todas de mesma área $\left(16 \mathrm{~cm}^{2}\right)$.

\subsubsection{Absorção de água pelas espumas}

Amostras de embalagens (espumas) de fécula de mandioca (14 cm x $9 \mathrm{~cm}$ x 0,25 $\mathrm{cm}$ ) foram pesadas e imersas em $500 \mathrm{~mL}$ de água, em um pirex, por 10 segundos à temperatura ambiente. Em seguida, as amostras foram secas com auxílio de um pano seco 
e, em seguida, pesadas novamente. Foram utilizadas duas amostras para cada formulação, tirando-se a média no final.

A quantidade de água absorvida pelas embalagens (espumas), de cada formulação, foi calculada segundo a equação:

$$
\text { Teor de absorção de água }(\%)=\frac{\text { massa }_{(\mathrm{u})}-\operatorname{massa}_{(\mathrm{s})}}{\operatorname{massa}_{(\mathrm{s})}} X 100
$$

em que: $\operatorname{massa}_{(\mathrm{u})}=$ massa úmida e $\operatorname{massa}_{(\mathrm{s})}=$ massa seca.

\subsubsection{Testes de prateleira das embalagens}

Amostras de embalagens (espumas) de fécula de mandioca (14 $\mathrm{cm} \times 9 \mathrm{~cm} \times 0,25$ $\mathrm{cm}$ ) foram armazenadas, em laboratório, com e sem controle de temperatura e umidade por cerca de cinco meses. No teste de prateleira com controle de temperatura e umidade as amostras foram armazenadas em estufa (como mostra a FIG. 13), de acordo com a norma ASTM 104 - 85 - "Standard practice for mantaining constant humidity by means of aqueous solutions" (Philadelphia, 1996). A temperatura na estufa variou de $20,0^{\circ} \mathrm{C}$ a $25,0^{\circ} \mathrm{C}$ e a umidade relativa de $70 \%$ a $80 \%$. Foram utilizadas duas amostras para cada formulação - uma amostra para o teste de prateleira sem controle e a outra amostra para o teste de prateleira com controle de temperatura e umidade.
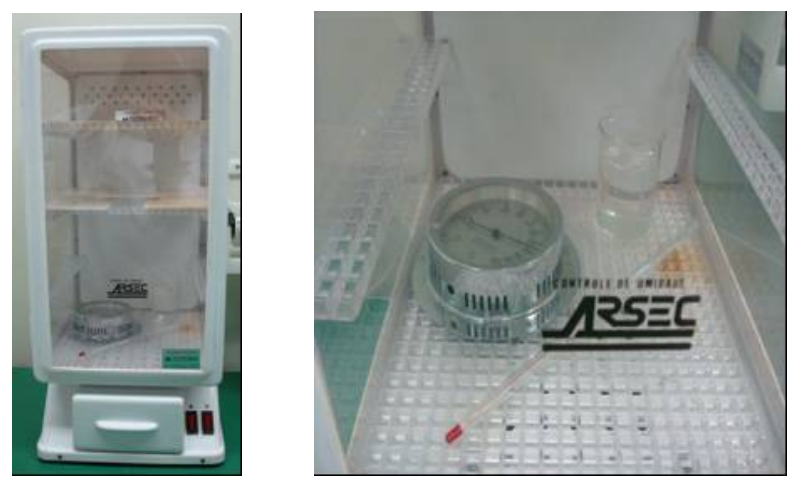

FIGURA 13 - Fotografia das amostras de embalagens (espumas) armazenadas em estufa com termômetro e medidor de umidade.

O teor de umidade da embalagem (espuma) durante a armazenagem, com e sem controle de temperatura e umidade, foi calculado como porcentagem em relação à massa 
inicial da embalagem. As pesagens foram feitas no tempo zero (ao sair da prensa) e, depois, de dois em dois dias com auxílio de uma balança digital.

O teor de umidade das embalagens foi calculado com base na seguinte fórmula:

$$
\text { Teor de umidade }(\%)=\frac{\operatorname{massa}_{(\mathrm{u})}-\operatorname{massa}_{(\mathrm{s})}}{\operatorname{massa}_{(\mathrm{s})}} \times 100
$$

em que: $\operatorname{massa}_{(\mathrm{u})}=$ massa úmida e $\operatorname{massa}_{(\mathrm{s})}=$ massa seca.

\subsubsection{Ensaios de resistência à tração e alongamento na ruptura das embalagens}

Para determinar as propriedades mecânicas das embalagens (espumas) de fécula de mandioca, testes de resistência à tração e alongamento na ruptura foram realizados de acordo com o método de ensaio padrão ASTM D828-97. As amostras de espumas e de isopor (poliestireno expandido) foram cortadas em formato retangular, $10 \mathrm{~cm} \mathrm{x} 4 \mathrm{~cm}$, e encaminhadas ao laboratório de Química da USP (Universidade de São Paulo) que dispõe de um texturômetro TA.XT2i da Stable Micro System, Inglaterra, com sonda cilíndrica de $36 \mathrm{~mm}$ de diâmetro e apoio anular (base) de $63 \mathrm{~mm}$ de diâmetro (FIG. 14). Durante os ensaios, a sonda cilíndrica se movimentava em direção a amostra, de cima para baixo, com velocidade de $1,00 \mathrm{~mm} / \mathrm{s}$ e com força de $0,25 \mathrm{~N}$ (25 g). Para cada formulação foram utilizadas seis amostras.

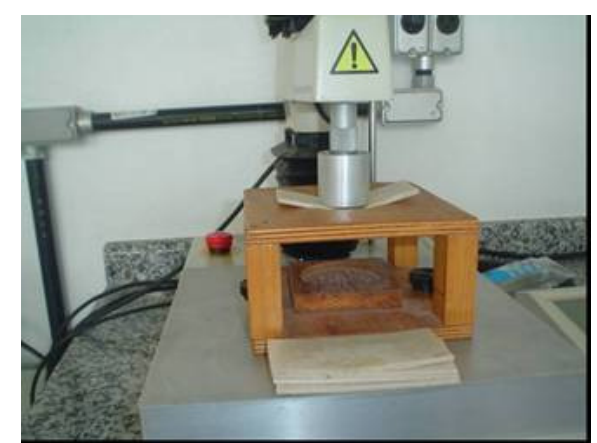

FIGURA 14 - Fotografia do ensaio de resistência à tração e alongamento na ruptura das espumas.

Para estes ensaios, as deformações relativas no ponto de ruptura podem ser determinadas segundo a equação: 


$$
\delta=\Delta \mathrm{L} / \mathrm{D}
$$

onde $\Delta \mathrm{L}=$ deslocamento vertical da sonda a partir do momento que tocou a amostra até o momento de ruptura da amostra; D = diâmetro da amostra em teste, ou seja, o diâmetro da base.

\subsubsection{Biodegradação das espumas}

Para determinar o tempo de degradação das espumas de fécula de mandioca foi utilizado o método de perda de massa. Esse método consiste em colocar as amostras (retangulares: $5,0 \mathrm{~cm} \times 7,0 \mathrm{~cm}$ ) das embalagens (espumas) dentro de uma porção de terra contida em béqueres devidamente identificados.

A cada dois dias desenterramos as espumas e pesamos em balança digital até sua total degradação. Durante o teste os béqueres contendo as embalagens totalmente enterradas foram armazenados em um armário "ventilado", com controle de temperatura e umidade relativa. Foi utilizado um solo simulado (terra, areia e esterco bovino) nesses estudos.

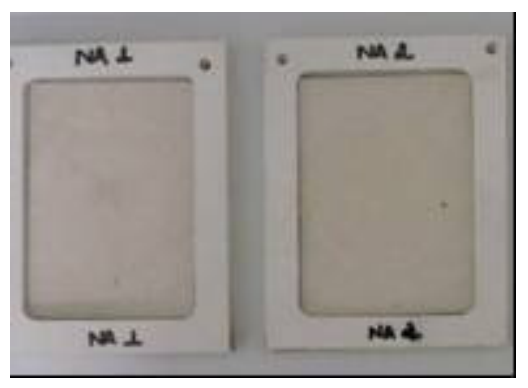

(a)

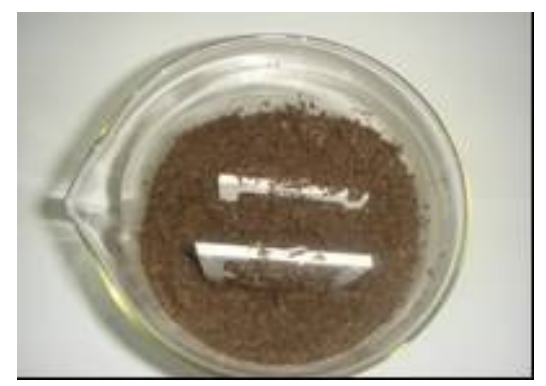

(b)

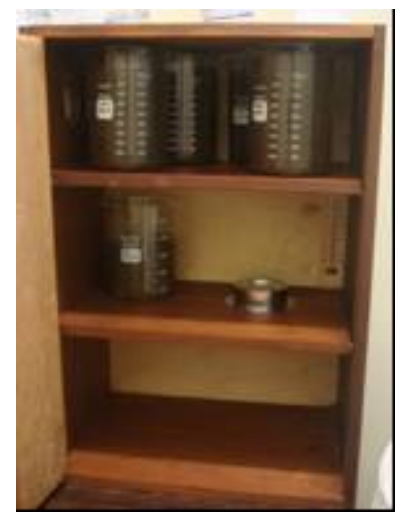

(c)

FIGURA 15 - Fotografias do método de estudo de biodegradação das espumas por perda de massa. (a): amostras de espumas retangulares; (b): amostras de espumas parcialmente enterradas em béquer; (c): béqueres armazenados em armário "ventilado", com termômetro e medidor de umidade.

\subsubsection{Testes sensoriais das embalagens}

Inicialmente foi feita a higienização das mãos, utensílios e área de trabalho com detergente e água, seguida da higienização das frutas com uso de esponja, detergente e 
água. As frutas foram descascadas e cortadas em fatias/pedaços de aproximadamente 2,5 $\mathrm{x}$ $3,0 \mathrm{~cm}^{2}$, sobre uma tábua plástica de cozinha; em seguida, foram transferidas para um pirex revestido por papel filme (como mostra a FIG. 16) de modo a evitar reações de oxidação e escurecimento. As frutas foram acondicionadas em potes de polipropileno (5,5 $\mathrm{cm}$ de diâmetro x 4,5 cm de altura), selados com espumas de fécula de mandioca, com e sem agentes ativos, e isopor e em embalagens de polietileno. As frutas foram armazenadas em geladeira (FIG. 17) a $10^{\circ} \mathrm{C}$ por 20 dias. A cada dois dias foram retiradas da geladeira para análises químicas, físicas e sensoriais.
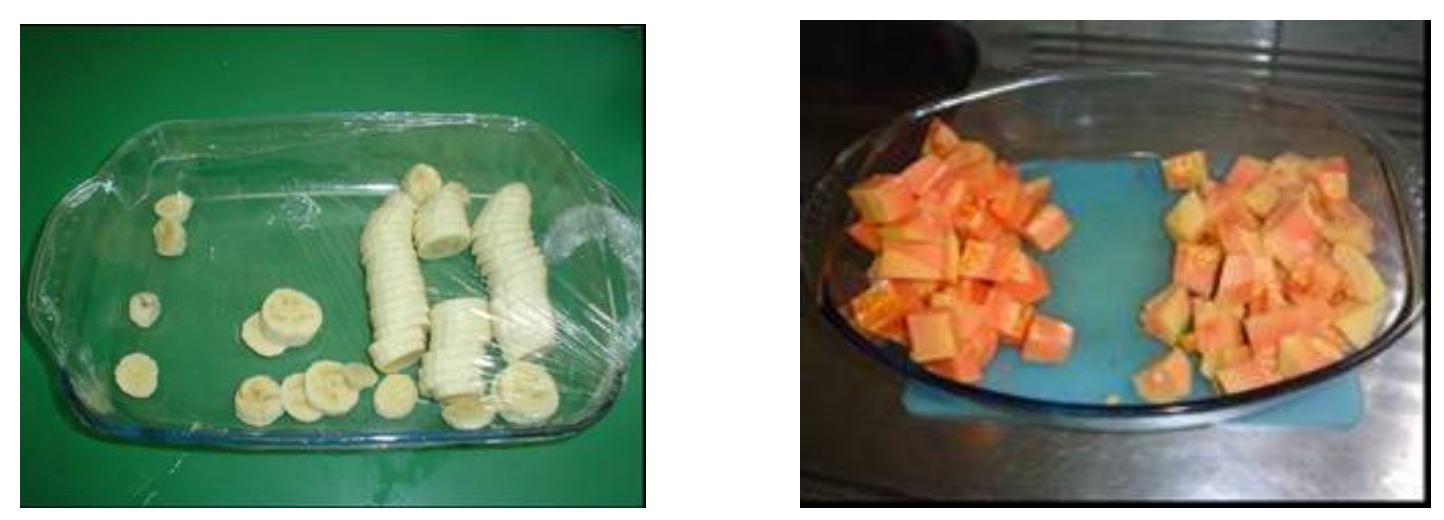

FIGURA 16 - Fotografias das frutas (banana e mamão) cortadas e armazenadas em pirex revestidos por papel filme.

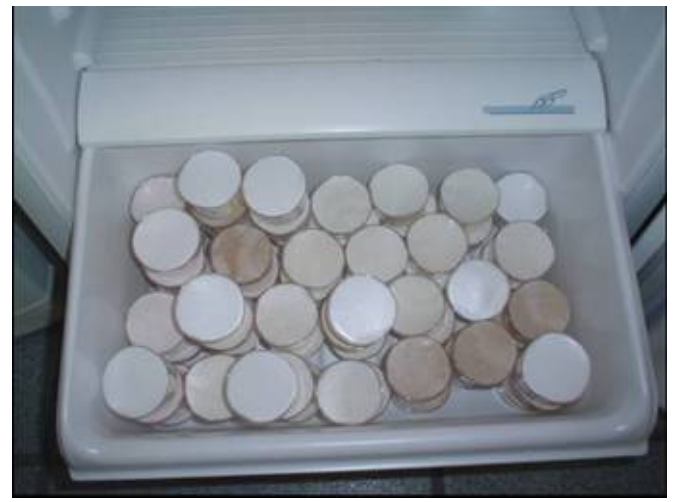

FIGURA 17 - Fotografia das frutas acondicionadas em potes de polipropileno e em embalagens de polietileno, armazenados em geladeira.

\subsubsection{Análises físico-químicas das frutas}

As análises físico-químicas seguiram a metodologia da AOAC (1997) que consiste na redução de massa fresca $(\%)$ - medida pela diferença entre o peso inicial e final - e pH, medido em pHmetro digital de bancada PG2000. 


\subsubsection{Análise estatística}

Os dados obtidos nos ensaios de resistência à tração e alongamento na ruptura das espumas foram analisados pela Análise de Variância Multifator (ANOVA), no método Thukey, com intervalo de confiança de $95 \%$. Para tanto, utilizou-se o software Stath Graphics Plus, versão 2.1. 


\section{RESULTADOS E DISCUSSÃO}

\subsection{Produção das embalagens de fécula de mandioca tipo espuma}

As embalagens foram obtidas por termoprensagem de uma mistura de fécula de mandioca (55\% em massa) e gel (fécula de mandioca dispersa em água) - sem plastificantes (glicerol e PEG 300) - a cerca de $190^{\circ} \mathrm{C}$, durante um minuto. As embalagens foram preparadas, individualmente, em forma de placa $(2,5 \mathrm{~mm}$ de espessura). Em seguida, as espumas ainda quentes foram removidas manualmente da prensa. $\mathrm{O}$ aspecto das espumas (preparadas em laboratório) sem plastificantes é apresentado na FIG. 18.

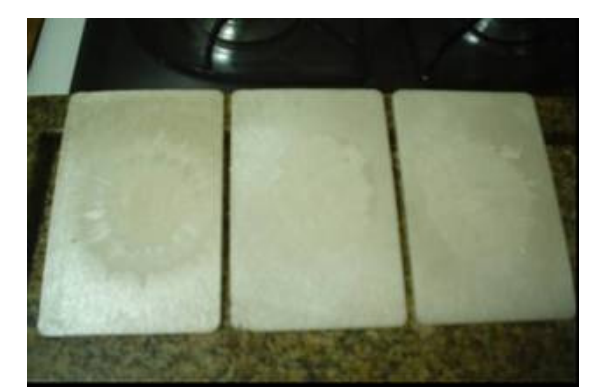

FIGURA 18 - Espumas sem plastificantes, com 55\% de fécula de mandioca (formulação SP), em forma de placa, obtidas em laboratório.

Em geral, as espumas apresentam uma superfície lisa e um aspecto uniforme, de cor amarelada, quase sem manchas; a mancha no centro das espumas é decorrente do processo de termoprensagem.

As espumas formuladas sem aditivos - ou seja, sem plastificantes, e com 55\% de fécula de mandioca - foram submetidas aos ensaios mecânicos de tração, medindo-se a resistência à tração e o alongamento na ruptura. Para efeito de comparação, foram determinados a resistência e o alongamento das embalagens de poliestireno expandido (isopor). Os resultados estão apresentados na FIG. 19. 

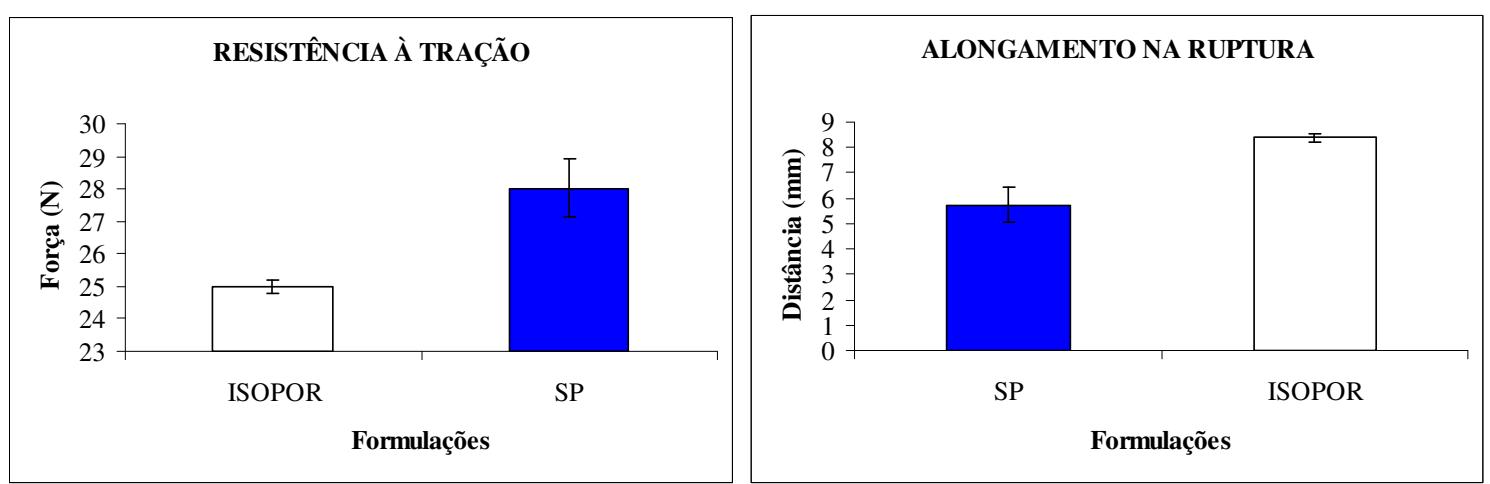

FIGURA 19 - Resistência à tração e alongamento na ruptura das espumas sem plastificantes, com $55 \%$ de fécula de mandioca (formulação SP), e do isopor.

As espumas de fécula de mandioca (SP) demonstraram ser mais resistentes à tração $(28,0 \pm 0,9 \mathrm{~N})$, porém menos flexíveis $(5,73 \pm 0,69 \mathrm{~mm})$ do que as embalagens de isopor, de alongamento $8,40 \pm 0,17 \mathrm{~mm}$ e resistência à tração de 25,0 \pm 0,2 $\mathrm{N}$. Essa diferença de flexibilidade provavelmente se deve à cristalinidade das embalagens - o poliestireno expandido (isopor) possui menor cristalinidade em relação às espumas de fécula.

As espumas de fécula de mandioca são totalmente solúveis em água e não oferecem boa qualidade na estocagem de produtos que eliminem água. Na FIG. 20 pode-se observar uma espuma de fécula de mandioca atacada pela água.

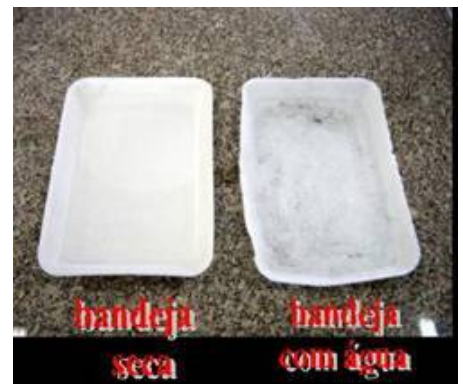

FIGURA 20 - Espumas de fécula de mandioca seca e com água.

Com base no exposto, foram estudadas:

(1) a adição de diferentes tipos de plastificante (glicerol e polietilenoglicol - PEG 300) à massa, em diversas concentrações, para aumentar a flexibilidade das espumas;

(2) a adição de diferentes quantidades de sólido (fécula de mandioca) à massa para aumentar a resistência das espumas à tração; 
(3) a incorporação de fécula modificada à formulação da espuma para melhorar a resistência à tração e à água;

(4) a utilização da fécula de mandioca produzida em dois diferentes estados brasileiros (Bahia e Paraná);

(5) a reutilização da espuma produzida para obtenção de novas espumas.

\subsubsection{Adição de plastificantes à massa}

A resistência das espumas à tração e o alongamento na ruptura estão diretamente relacionados ao teor de umidade do material (a água é o principal plastificante). As espumas, ainda quentes, ao saírem do molde são quebradiças e, portanto, pouco resistentes à tração. Diferentemente do desenvolvimento dos materiais plásticos, o de produtos à base de amido tem sido fortemente impedido pelo limitado desempenho mecânico, geralmente atribuído à elevada ramificação da estrutura da amilopectina, juntamente à sua hidrofilicidade intrínseca (Chaléat et al., 2008). Por ser o amido um material higroscópico, ele pode absorver água sob diferentes umidades relativas do ambiente, alterando as propriedades físicas e mecânicas dos polímeros.

As espumas produzidas sem os plastificantes glicerol ou PEG 300 (formulação SP), ainda quentes, ao saírem do molde são quebradiças e, portanto, pouco resistentes à tração. Para aumentar a resistência mecânica das espumas foram adicionados polietilenoglicol (PEG 300) ou glicerol como plastificantes.

Tang et al. (2008b) estudaram a influência do glicerol e de diferentes plastificantes (ureia e formamida) na formação da nanoestrutura e nas propriedades de filmes nanocompósitos de amido-argila e verificaram que a presença de plastificantes contribuiu positivamente para as propriedades mecânicas, térmicas e de barreira dos filmes. Segundo os autores, filmes com 5\% de glicerol exibiram a menor permeabilidade ao vapor d'água $\left(0,41\right.$ g.mm/kPa.h.m $\left.{ }^{2}\right)$, surpreendentemente maior temperatura de transição vítrea $\left(53,78^{\circ} \mathrm{C}\right)$, e maior força de tração $(35 \mathrm{MPa})$, porém baixo alongamento na ruptura $(2,15 \%)$.

As espumas com $55 \%$ de fécula de mandioca contendo os diferentes tipos de plastificantes, nas concentrações de 1\%,2\% e 5\% foram submetidas a ensaios mecânicos (resistência à tração e alongamento) e de barreira (absorção de água) para verificar se as adições de plastificantes alteravam as propriedades mecânicas e de barreira das espumas. Para efeito de comparação, inserimos no gráfico a força de tração e o alongamento das espumas sem a adição de plastificante (com 55\% de fécula de mandioca - formulação SP). 
Na TAB. 2 são apresentados os resultados da absorção de água pelas espumas formuladas sem e com plastificantes nas diferentes concentrações.
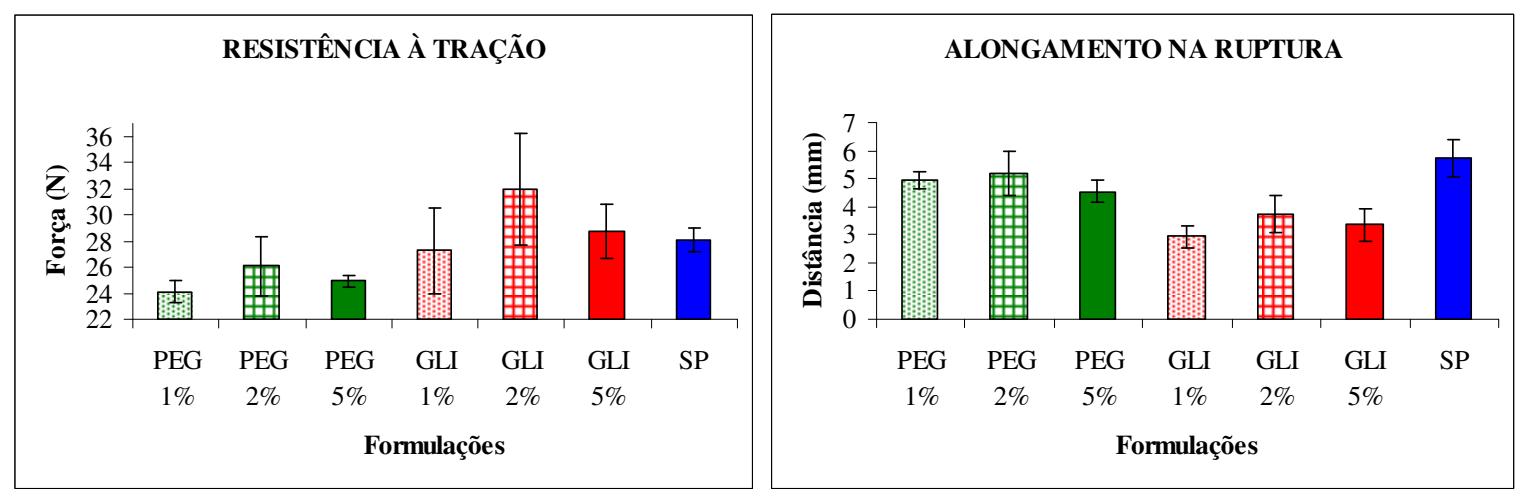

FIGURA 21 - Resistência à tração e alongamento na ruptura das espumas de fécula de mandioca (55\% de fécula) sem e com plastificantes, nas diferentes concentrações. PEG = polietilenoglicol (PEG 300); GLI = glicerol; SP = sem plastificante.

As adições de $2 \%$ e $5 \%$ do plastificante glicerol às espumas de fécula de mandioca aumentaram a resistência à tração. Segundo Rabello (2000), quando há interação entre os plastificantes e o polímero, ocorre uma coesão global da estrutura do produto e tal homogeneidade propicia uma maior resistência mecânica na espuma. As forças de tração das espumas formuladas com $1 \%, 2 \%$ e $5 \%$ de glicerol foram, respectivamente, 27,3 $\pm 3,3$ $\mathrm{N}($ GLI 1\%), 31,9 $\pm 4,3 \mathrm{~N}($ GLI 2\%) e 28,7 $\pm 2,1 \mathrm{~N}$ (GLI 5\%), enquanto a força das espumas sem plastificante (SP) foi de $28,0 \pm 0,9$ N. Já a adição do plastificante polietilenoglicol (PEG 300) às espumas de fécula de mandioca não melhorou suas propriedades mecânicas. As resistências à tração das espumas formuladas com PEG 300 foram de 24,1 $\pm 0,8 \mathrm{~N}$ para a formulação contendo $1 \%$ de plastificante, $26,1 \pm 2,2 \mathrm{~N}$ para aquela contendo $2 \%$ de PEG 300, e 24,9 $\pm 0,4 \mathrm{~N}$ para aquela contendo 5\% de PEG 300. De acordo com a análise estatística de variância (ANOVA), para o parâmetro força, não houve diferença significativa $(\mathrm{p}<0,05)$ entre as formulações com $1 \%$ e $5 \%$ de plastificantes (glicerol e polietilenoglicol), porém houve diferença significativa $(\mathrm{p}>0,05)$ entre tais formulações e aquelas com $2 \%$ de plastificantes. A espuma sem plastificantes (formulação SP) não variou significativamente das formulações contendo $1 \%$ e $5 \%$ de glicerol (GLI $1 \%$ e GLI 5\%), mas variou significativamente das demais.

A adição dos plastificantes, tanto do glicerol quanto do polietilenoglicol (PEG 300), não melhorou o alongamento das espumas de fécula de mandioca, sendo as espumas 
formuladas com PEG 300 mais flexíveis do que aquelas formuladas com glicerol. Os alongamentos das espumas contendo 1\%, 2\% e 5\% de PEG 300 correspondem, respectivamente, a 4,93 $\pm 0,30 \mathrm{~mm}$ (PEG 1\%), 5,19 $\pm 0,76 \mathrm{~mm}($ PEG 2\%) e 4,55 $\pm 0,38$ $\mathrm{mm}$ (PEG 5\%), enquanto que aquelas contendo glicerol correspondem, respectivamente, a $2,95 \pm 0,40 \mathrm{~mm}$ (GLI 1\%), 3,73 $\pm 0,68 \mathrm{~mm}($ GLI 2\%) e 3,37 $\pm 0,57 \mathrm{~mm}$ (GLI 5\%). As espumas sem glicerol e polietilenoglicol (SP) foram as mais flexíveis $(5,73 \pm 0,69 \mathrm{~mm})$. De acordo com a análise estatística de variância (ANOVA), para o parâmetro distância, não houve diferença significativa $(\mathrm{p}<0,05)$ entre as formulações com $1 \%$ e $5 \%$ de PEG 300 (PEG 1\% e PEG 5\%), porém estas variaram significativamente ( $>>0,05)$ daquela com 2\% de PEG 300 (PEG 2\%). Das espumas plastificadas com glicerol, não houve diferença significativa entre aquelas contendo $2 \%$ e $5 \%$ de plastificante, porém estas variaram significativamente da espuma com $1 \%$ de glicerol. A espuma sem GLI e PEG 300 (formulação SP) diferiu significativamente $(p>0,05)$ de todas as espumas contendo plastificantes (formulações PEG e GLI).

Nota-se, ainda na FIG. 21, que a concentração de $2 \%$ de ambos os plastificantes (GLI 2\% e PEG 2\%) foi a melhor dentre as três alternativas testadas, representando espumas mais resistentes à tração e ao alongamento na ruptura.

As espumas de fécula de mandioca até então estudadas foram menos flexíveis do que as embalagens de poliestireno expandido (isopor) - resistente a uma força de 25,0 \pm $0,2 \mathrm{~N}$ e com alongamento de $8,40 \pm 0,17 \mathrm{~mm}$-, porém mais resistentes à tração, com exceção daquelas formuladas com 1\% e 5\% de PEG 300. O glicerol e o PEG 300 pouco contribuíram como plastificantes, e sim, para modificar a estrutura das espumas. 
TABELA 2 - Resultados da absorção de água pelas espumas de fécula de mandioca (55\% de fécula) sem e com plastificantes, nas diferentes concentrações, e pelo isopor.

\begin{tabular}{lc}
\hline \multicolumn{1}{c}{ Formulações } & Teor de absorção de $\mathbf{H}_{\mathbf{2}} \mathbf{O}^{*}(\boldsymbol{\%}) \pm$ Erro \\
\hline ISOPOR & $3,4 \pm 0,1$ \\
SP & $28,4 \pm 1,5$ \\
PEG 2\% & $29,9 \pm 0,9$ \\
PEG 5\% & $38,3 \pm 0,4$ \\
PEG 1\% & $40,5 \pm 0,8$ \\
GLI 2\% & $40,9 \pm 0,5$ \\
GLI 5\% & $47,2 \pm 1,8$ \\
GLI 1\% & $48,8 \pm 0,4$ \\
\hline * espumas imersas em 500 mL de água por 10 segundos à temperatura \\
ambiente. SP = espuma sem plastificante; PEG = polietilenoglicol (PEG \\
300); GLI = glicerol.
\end{tabular}

As embalagens (espumas) de fécula de mandioca absorveram água, sendo que as adições de PEG 300 e glicerol às espumas (formulações PEG e GLI) resultaram em um aumento de absorção de água por propiciarem, aparentemente, uma difusão mais rápida no interior das espumas. O glicerol é um plastificante hidrofílico bastante empregado que interage com as cadeias de amido, aumentando a mobilidade molecular e, consequentemente, a hidrofilicidade e a flexibilidade dos materiais plastificados (Mali et al., 2004). Tanto o plastificante polietilenoglicol como o glicerol apresentaram formulações de menor absorção de água na concentração de $2 \%$, seguida de $5 \%$ e, por último, de $1 \%$. Das formulações de espumas que contêm plastificante, a mais resistente à água foi aquela contendo 2\% de PEG 300.

Apesar de não serem as espumas mais resistentes à tração de todas as formulações estudadas até então, decidiu-se substituir as espumas anteriormente sem plastificantes (formulação SP) por espumas com o plastificante PEG 300, na concentração de $2 \%$ (formulação PEG 2\%). Tal concentração foi escolhida por ser a melhor dentre as três, ou seja, por tornar as espumas mais resistentes à tração e mais flexíveis.

Escolheu-se produzir espumas com o plastificante PEG 300 (2\%), pois essas se mostraram bastante flexíveis, apresentaram boa resistência à tração - maior que a do isopor, e comparável à das espumas sem plastificante - e baixa solubilidade em água; isso tudo além de outras variáveis, mostradas a seguir, em que se percebem vantagens, tais como: boa produtividade (não houve perda de produção), baixa absorção de umidade e 
rápida perda de massa. A TAB. 3 apresentam os resultados de perda de produção e de densidade das embalagens (espumas) de fécula de mandioca sem e com plastificantes glicerol e polietilenoglicol, ambos na concentração de $2 \%$.

TABELA 3 - Resultados da perda de produção e da densidade das espumas de fécula de mandioca sem e com plastificantes, na concentração de $2 \%$.

\begin{tabular}{lcc}
\hline Formulações* & Perda de produção $(\%)$ & Densidade \pm Erro $\left(\mathbf{g} / \mathbf{c m}^{3}\right)$ \\
\hline PEG 2\% & 0 & $0,20 \pm 0,01$ \\
SP & 7,1 & $0,21 \pm 0,01$ \\
GLI 2\% & 16,7 & $0,23 \pm 0,01$ \\
\hline * PEG 2\% = 2\% de PEG 300; SP = sem plastificante; GLI $2 \%=2 \%$ de \\
glicerol.
\end{tabular}

O resultado da perda de produção das espumas contendo PEG 300 (0\%) pode ser atribuído à melhor expansão da massa de amido no molde, funcionando, o plastificante PEG 300, como lubrificante de processo.

A FIG. 22 mostra o teor de umidade das espumas sem e com plastificantes (glicerol e PEG 300), na concentração de $2 \%$, ao longo dos dias sem controle de temperatura e umidade (a) e com controle de temperatura e umidade (b). A FIG. 23 mostra a perda de massa das espumas sem e com plastificantes, na concentração de $2 \%$. 


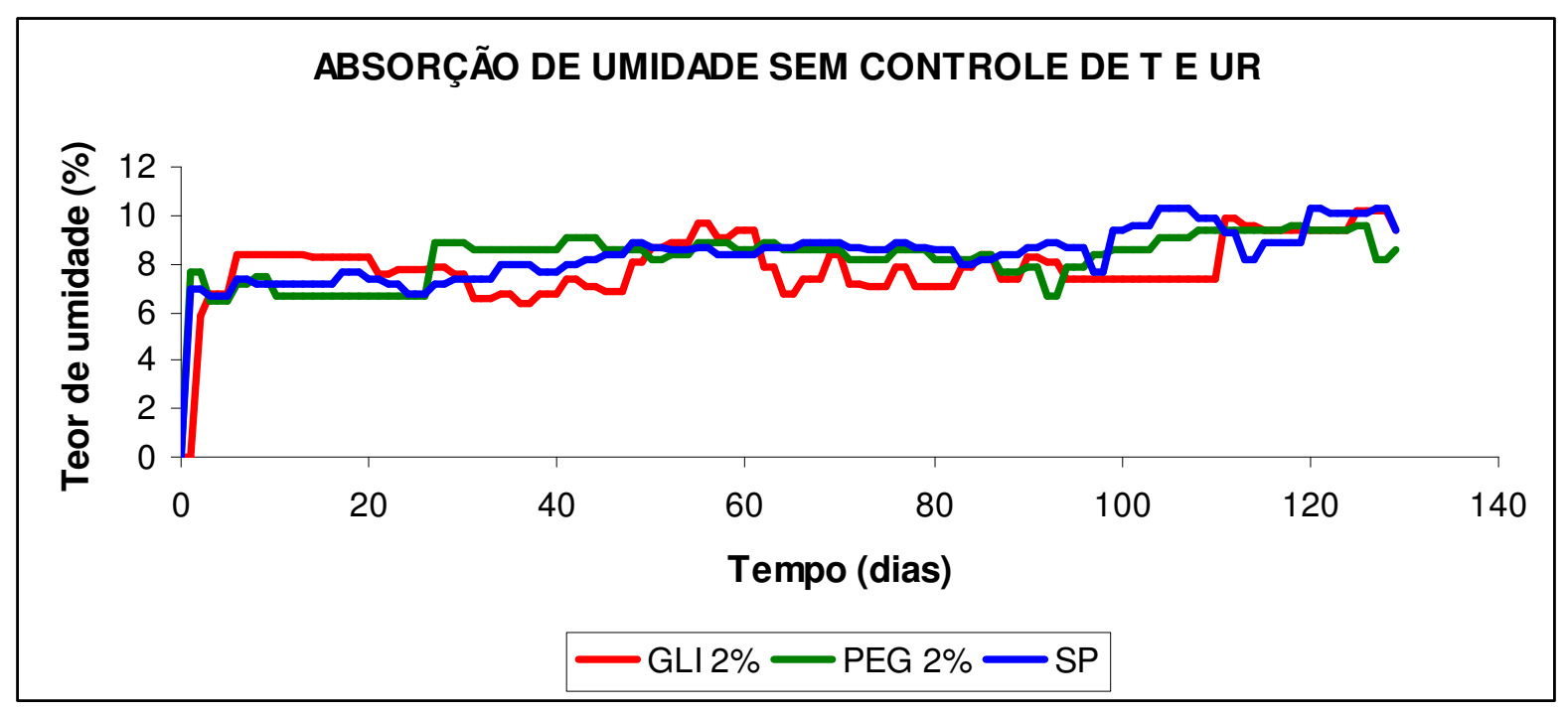

(a)

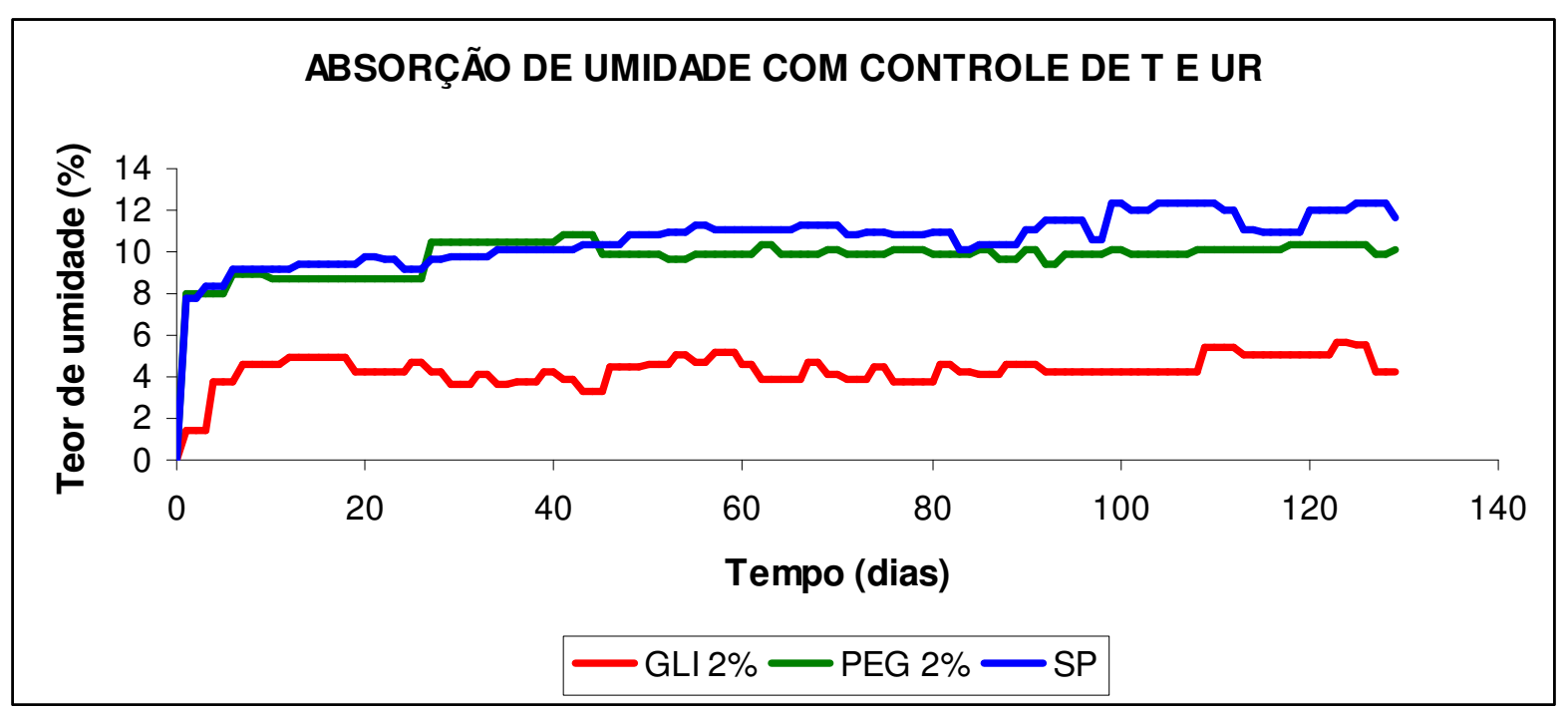

(b)

FIGURA 22 - Teor de umidade das espumas de fécula de mandioca sem e com plastificantes (na concentração de $2 \%$ ) ao longo dos dias, sem controle de temperatura e umidade (a) e com controle de temperatura e umidade (b). GLI 2\% $=2 \%$ de glicerol; PEG $2 \%=2 \%$ de PEG $300 ; \mathrm{SP}=$ sem plastificante.

Como era esperado, a absorção de umidade das espumas de fécula de mandioca é mais estável quando há controle de temperatura e umidade relativa. Nota-se na FIG. 22(a) que os resultados de absorção de umidade ao longo dos dias foram equivalentes, provavelmente por ser, a absorção, controlada pela parede da espuma - que, em todos os casos, se apresentou rígida e pouco porosa. Na FIG. 22(b) as espumas com glicerol (GLI 2\%) absorveram menos umidade ao longo dos dias, sendo, assim, menos flexíveis e, 
consequentemente, mais quebradiças em relação às demais espumas. Neste caso (absorção de umidade das espumas ao longo dos dias), o glicerol exerceu um efeito contrário ao descrito por Mali et al. (2004), de decréscimo de hidrofilicidade, já relatado por outros autores, que estudaram este plastificante em diferentes combinações e com outros tipos de amido, como efeito antiplastificante (Mali e al., 2005; Chang et al., 2006). De acordo com Lourdin et al. (1997), o efeito antiplastificante pode ser evidenciado pelo decréscimo da hidrofilicidade sob baixos valores de Aa (atividade de água) e baixos teores de plastificante, e é um indicativo de que interações mais fortes entre o plastificante e o biopolímero (amido) estejam ocorrendo - neste caso, interações do tipo ligações de hidrogênio, que induzem a um decréscimo da mobilidade molecular. As espumas formuladas com o plastificante polietilenoglicol (PEG 2\%) são mais resistentes à ruptura ao saírem do molde, ou seja, no tempo zero.

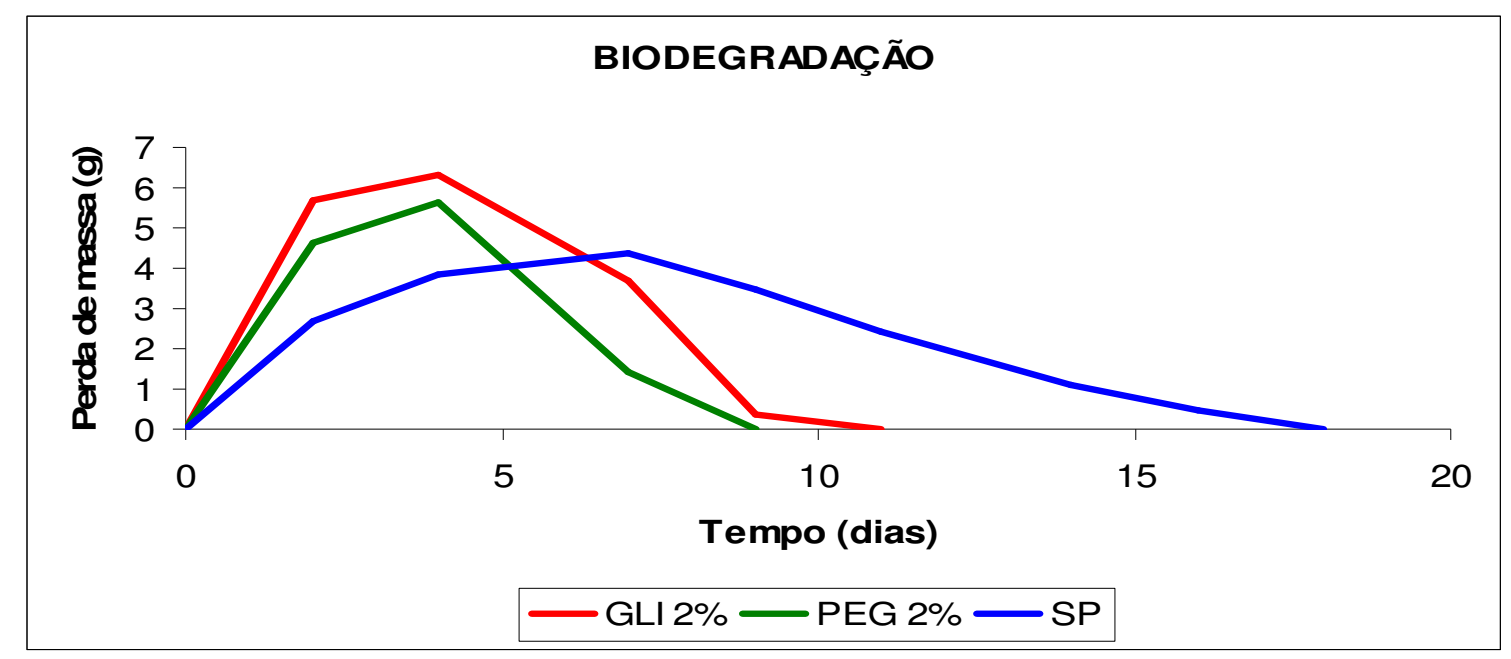

FIGURA 23 - Perda de massa das espumas de fécula de mandioca sem e com plastificantes, na concentração de $2 \%$. GLI 2\% = 2\% de glicerol; PEG $2 \%=2 \%$ de PEG 300; $\mathrm{SP}=$ sem plastificante.

A adição de plastificantes diminuiu o tempo de perda de massa das espumas de fécula de mandioca por torná-las mais sensíveis à umidade. As espumas contendo polietilenoglicol (PEG 2\%) e glicerol (GLI 2\%) reduziram totalmente suas massas, respectivamente, em cerca de 9 e 11 dias, enquanto aquela sem plastificante (SP) perdeu sua massa total em cerca de 18 dias. 


\subsubsection{Variação da quantidade de sólidos (fécula de mandioca em pó) na massa}

As espumas foram feitas, até então, com $55 \%$ de fécula de mandioca em pó, adicionada juntamente ao gel (fécula dispersa em água) e o plastificante no misturador de laboratório.

O tempo de vida da massa (mistura da fécula, gel e plastificante) está diretamente ligado à quantidade de água presente na formulação e à quantidade de água perdida pela massa em função da temperatura e umidade do seu armazenamento. Isso acontece porque a água é responsável pela expansão do amido e pela obtenção da espuma. Perdendo-se água, perde-se o poder de expansão e mais massa é necessária para suprir a falta de água. Para manter a estabilidade da massa alteramos a viscosidade da massa, aumentando a quantidade de fécula na formulação e diminuindo a quantidade de água livre no sistema. No entanto, segundo Shogren et al. (1998), espumas mais densas e fortes são produzidas aumentando-se o teor de amilose e a concentração de amido; porém, espumas mais densas costumam ser menos flexíveis.

Assim, foram produzidas espumas com $57 \%$ de fécula de mandioca em suas formulações (e com 2\% do plastificante polietilenoglicol - PEG 300). A formulação antes conhecida como PEG $2 \%$ será denominada, de agora em diante, F 55\%. A espuma contendo $57 \%$ de fécula de mandioca em pó será denominada F 57\%.

Os resultados dos testes de perda de produção (representada em \%), a quantidade média de massa necessária para formar uma embalagem (espuma completa sem bolhas nem rachaduras), a densidade e a absorção de água (representada em \%) das espumas de diferentes concentrações de fécula de mandioca (55\% e 57\%) estão apresentados na TAB. 4. 
TABELA 4 - Resultados da quantidade média de massa necessária para formar uma embalagem (espuma), da perda de produção, da densidade, da solubilidade e dos testes mecânicos (resistência à tração e alongamento na ruptura) das espumas de diferentes concentrações de fécula de mandioca (em pó).

\begin{tabular}{|c|c|c|}
\hline \multirow{2}{*}{ Análises } & \multicolumn{2}{|c|}{ Formulações* } \\
\hline & F 55\% & F $57 \%$ \\
\hline $\begin{array}{l}\text { Quantidade de massa para } \\
\text { formar uma espuma (g) }\end{array}$ & 7,86 & 8,00 \\
\hline Perda de produção (\%) & 0 & 0 \\
\hline Densidade $\left(\mathrm{g} / \mathrm{cm}^{3}\right)$ & $0,20 \pm 0,01$ & $0,21 \pm 0,02$ \\
\hline Teor de absorção $\mathrm{H}_{2} \mathrm{O}(\%)$ & $29,8 \pm 0,9$ & $37,0 \pm 0,1$ \\
\hline Força $(\mathbf{N})$ & $26,1 \pm 2,2$ & $27,4 \pm 2,3$ \\
\hline Distância (mm) & $5,19 \pm 0,76$ & $4,27 \pm 0,74$ \\
\hline
\end{tabular}

Nota-se pela TAB. 4 que as espumas com diferentes concentrações de fécula em pó (formulações F 55\% e F 57\%) são muito semelhantes, diferindo mais significativamente quanto à absorção de água (teor de absorção de $\mathrm{H}_{2} \mathrm{O}$ ). A formulação com $57 \%$ de fécula de mandioca absorveu praticamente $7 \%$ mais água do que aquela contendo $55 \%$ de fécula. A espuma com maior quantidade de fécula mostrou viscosidade um pouco maior, sendo necessária uma maior quantidade de massa para formar uma espuma completa. Já a espuma com menor quantidade de fécula apresentou viscosidade um pouco menor e precisou de uma menor quantidade de massa para formar uma espuma completa. Este resultado está de acordo com Lawton et al. (1999) e com Carr (2007) que demonstraram que a quantidade de massa para formar espuma aumenta com o aumento da viscosidade. $\mathrm{O}$ ideal é que a massa de fécula seja fluida o suficiente para expandir e tenha viscosidade suficiente para reter (prender) em sua estrutura o vapor de água gerado, formando alvéolos (bolhas) de tamanho e distribuição uniformes, obtendo-se assim, características de espuma (Shogren et al., 1998; Lawton et al., 1999; Zitny et al., 2002).

Não houve perda de produção em ambas as formulações, com diferentes concentrações de sólido (fécula de mandioca em pó). Isso provavelmente se deve ao fato da pequena diferença de viscosidade entre as espumas, não interferindo nas suas produtividades. 
Como pode ser observado, ainda na TAB. 4, não houve diferença significativa na força das espumas com o aumento da quantidade de sólidos na massa; no entanto, houve aumento da densidade das espumas e diminuição de seu alongamento. Resultados semelhantes foram obtidos por Lawton et al. (1999) que estudaram as propriedades mecânicas de espumas de amido de milho, batata e trigo com diferentes quantidades de sólidos na massa (variando de 25 a 45\%). Os autores observaram que quanto maior essa quantidade, mais resistentes e menos flexíveis eram as espumas produzidas por termoexpansão. Para Carr (2007), os valores de resistência à tração e densidade das espumas de fécula de mandioca aumentaram, já o alongamento diminuiu com maior quantidade de fécula na massa.

Apesar de serem mais densas e menos flexíveis do que as espumas produzidas com $55 \%$ de sólidos na massa, estudou-se a influência do amido modificado (química e fisicamente) na composição das espumas produzidas com $57 \%$ de sólidos na massa. Essas espumas, ao saírem do molde, são menos quebradiças do que as espumas formuladas com $55 \%$ de sólido na massa. Isso porque absorvem mais água, como pode ser observado na TAB. 4. Como a água tem poder plastificante, as espumas com $57 \%$ de sólidos são mais resistentes à tração, facilitando assim o manuseio das peças e evitando perdas durante a armazenagem.

Como pode ser observado na FIG. 24, as espumas produzidas com 57\% de sólidos perderam completamente sua massa em 14 dias, contra apenas 9 dias das espumas produzidas com 55\%. Quanto maior a quantidade de massa seca (fécula de mandioca em pó) utilizada para obtenção das espumas, mais tempo levarão para completa perda de massa. 


\section{BIODEGRADAÇÃO}

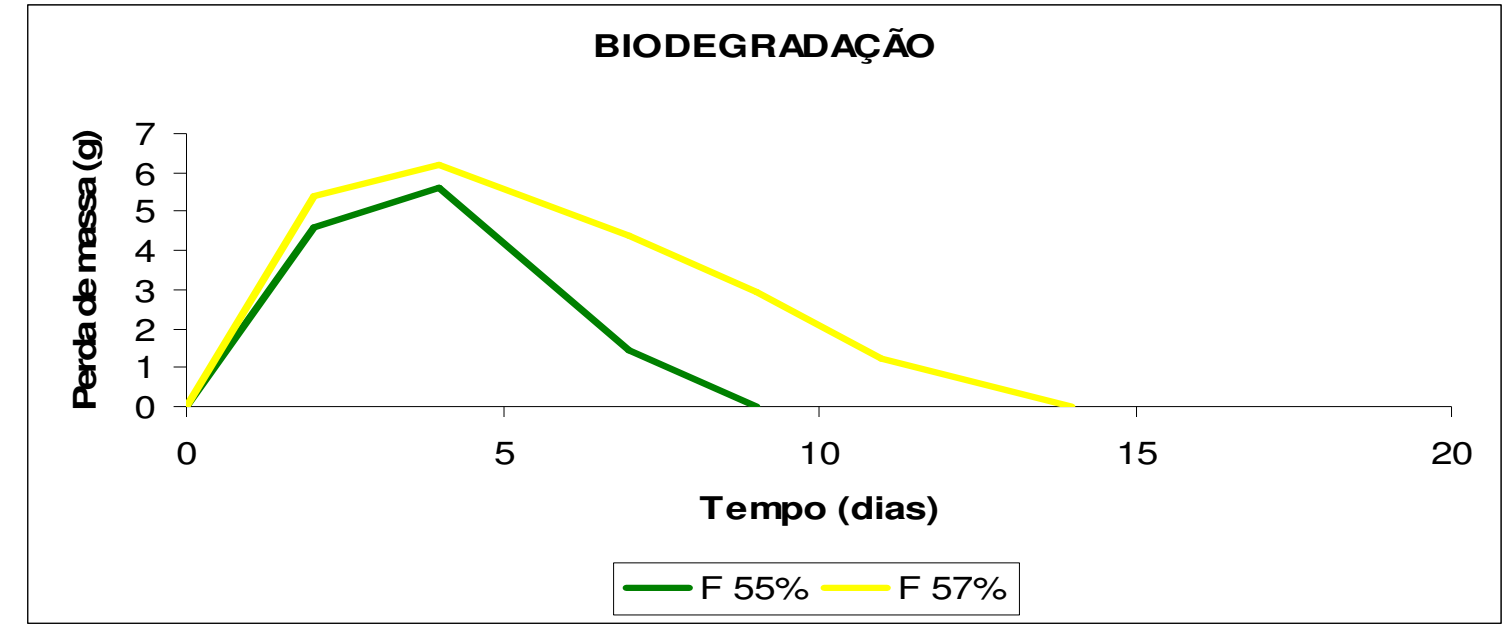

FIGURA 24 - Perda de massa das espumas de fécula de mandioca em diferentes concentrações de sólido (fécula). F 55\% = 55\% de fécula de mandioca; F 57\% = 57\% de fécula de mandioca.

\subsubsection{Tratamentos da fécula de mandioca, uso de outro fornecedor de fécula e reaproveitamento das espumas}

O processamento de amido é muito mais complicado e difícil de controlar do que o de polímeros convencionais, devido às propriedades de processamento insatisfatórias como resultado de suas transições de fase única, elevada viscosidade, evaporação de água, rápida retrogradação, etc (Liu et al., 2009). Entretanto, com o desenvolvimento de formulação apropriada e condições de processamento adequadas, muitos desses desafios podem ser superados (Liu et al., 2009).

O tipo de amido, a sua modificação química e as condições de processamento adaptadas têm sido capazes de aperfeiçoar o produto final (Halley et al., 2006). Quando o tipo de amido e a velocidade da rosca (processo de extrusão) são considerados juntos, eles têm mostrado um grande efeito nas propriedades de extrusão e do produto acabado (Chaudhary et al., 2008). Segundo Van Soeste et al. (1996), o aumento da velocidade da rosca aumentou a cristalinidade de amidos com maior teor de amilose e, consequentemente, afetou as propriedades mecânicas do produto final. $\mathrm{O}$ uso de amidos modificados tem sido também uma alternativa para reduzir a absorção de água de materiais à base de amido (Lafargue et al., 2007).

A modificação dos amidos nativos é um fator importante para proporcionar propriedades funcionais de espessamento, gelificação, adesão e/ou formação de filmes (Cereda e Vilpoux, 2003). A National Starch and Chemical (1997) cita também que a 
modificação de amidos permite melhorar a retenção de água, aumentar a estabilidade, gelificar, dispersar ou conferir opacidade ao material.

As modificações do amido podem ser feitas por métodos físicos ou químicos. A modificação física é feita por meio de calor e umidade (pré-gelatinização), enquanto tratamentos químicos envolvem a introdução de grupos funcionais na molécula de amido, utilizando reações de derivatização (eterificação, esterificação, reticulação e enxertia) ou decomposição (hidrólise ácida ou enzimática e oxidação) (Wurzburg, 1986; Singh et al., 2007). O conhecimento sobre os efeitos das modificações químicas e físicas nas estruturas granulares de amido é necessário para compreender suas propriedades funcionais e permitir o desenvolvimento de amidos com propriedades desejadas para seu melhor uso, especialmente na indústria de alimentos (López et al., 2010).

Assim, com base no exposto, foram estudados diferentes processos de produção das espumas de fécula de mandioca por meio de modificações química (acetilação) formulação FMQ - e físicas (pré-gelatinização - formulação FPG - e irradiação formulações FI) da fécula. Além disso, espumas foram produzidas a partir de diferentes fornecedores de fécula: do estado do Paraná (Companhia Lorenz) - formulação FOR - e da Bahia (Flor de Lótus Inc.) - formulação F57\%; e ainda as espumas já fabricadas foram reaproveitadas para obtenção de novos produtos espumados (formulação REA). As espumas foram produzidas com base na formulação contendo $57 \%$ de fécula e $2 \%$ de polietilenoglicol (PEG 300) como plastificante.

Tais espumas foram submetidas a ensaios mecânicos (resistência à tração e alongamento) para verificar se os diferentes tratamentos dados à fécula de mandioca modificações química e física -, a utilização de fécula originária de outro estado brasileiro e o reaproveitamento de espumas alteraram as propriedades das embalagens. Os resultados estão apresentados na FIG. 25. 

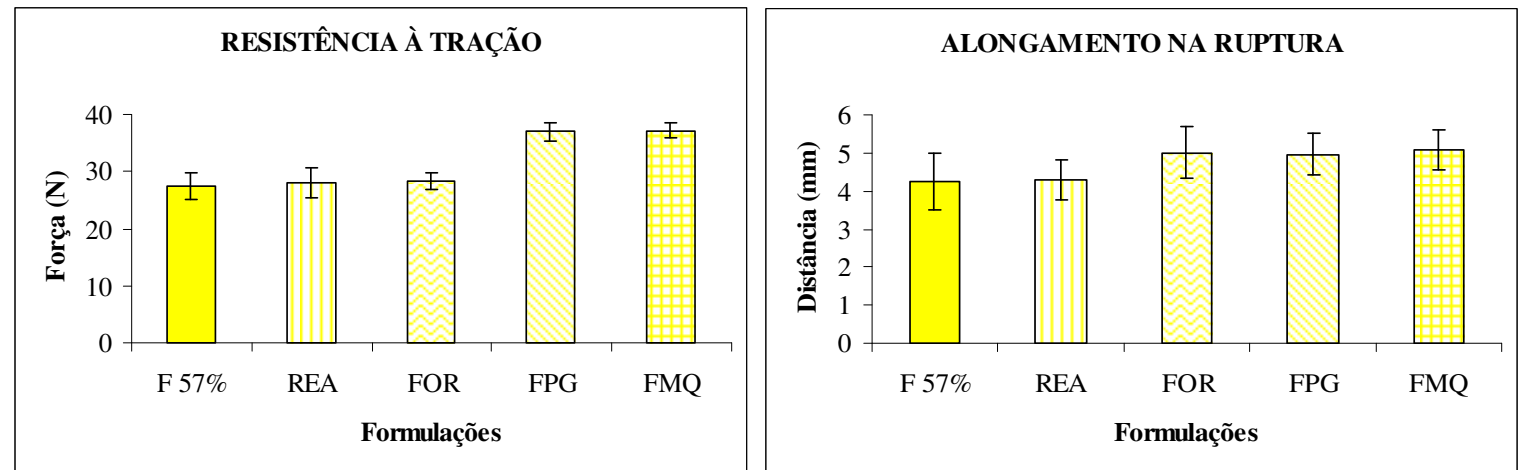

FIGURA 25 - Resistência à tração e alongamento na ruptura das espumas sem tratamento, com diferentes tratamentos, de diferentes fornecedores de fécula de mandioca e das espumas reaproveitadas. $\mathrm{F} 57 \%=$ sem tratamento da fécula; $\mathrm{REA}=$ reaproveitamento das espumas; FOR = fécula proveniente do estado do Paraná (marca Lorenz); FPG = fécula pré-gelatinizada; FMQ = fécula modificada quimicamente.

Os estudos dos diferentes tratamentos da fécula de mandioca, ou seja, a prégelatinização (uma das modificações físicas estudadas) e a modificação química (acetilação) da fécula, a utilização de fornecedores de dois estados brasileiros e o reaproveitamento de espumas, possibilitaram a escolha de uma combinação de fatores que gerou espumas com ótimas propriedades mecânicas.

As espumas com a fécula modificada quimicamente (formulação FMQ) mostraram ser as mais resistentes à tração e ao alongamento, com uma força de $37,2 \pm 1,3 \mathrm{~N}$ e alongamento de 5,10 \pm 0,53 mm, enquanto aquelas sem tratamento da fécula (formulação $F$ $57 \%$ ) foram as menos resistentes à tração e alongamento, com uma força de 27,4 $\pm 2,3 \mathrm{~N} \mathrm{e}$ alongamento de 4,27 $\pm 0,74 \mathrm{~mm}$. Estes resultados estão de acordo com Larotonda et al. (2004), que estudaram as propriedades mecânicas de filmes com amido de mandioca puro e com amido de mandioca modificado quimicamente por acetilação. Os autores verificaram que as amostras contendo amido modificado foram 1,5 vezes mais resistentes do que aquelas com amido sem modificação. Determinações precisas dos graus de substituição (GS) dos acetatos de amido são necessárias para estabelecer importantes relações estrutura-propriedades a esta classe de polímeros. Por exemplo, a solubilidade do amido substituído depende de seu grau de substituição. A introdução de grupos acetil interrompe a estrutura ordenada do amido nativo e interfere com a re-associação de amilose e amilopectina do amido gelatinizado, levando à diminuição da temperatura de gelatinização, aumento da solubilidade e melhora da estabilidade de armazenamento (Elomaa et al., 2004). Segundo Bello-Pérez et al. (2010), o grau de acetilação afetou a 
estrutura do amido de cevada, com significativa redução na viscosidade, na temperatura e entalpia de gelatinização, e na retrogradação, principalmente devido à despolimerização (ruptura) dos componentes de amido.

A segunda formulação mais resistente à tração foi aquela em que a fécula foi prégelatinizada (formulação FPG: 37,0 $\pm 1,7 \mathrm{~N}$ ), seguida daquela com fécula proveniente do estado do Paraná (formulação FOR: $28,3 \pm 1,6 \mathrm{~N}$ ) e, por último foi a que houve o reaproveitamento de espumas (formulação REA: 28,0 \pm 2,6 N).

Ao se analisar os valores de força das espumas sem tratamento da fécula (formulação F 57\%), daquelas reaproveitadas (formulação REA) e daquelas de diferentes fornecedores de fécula (formulação FOR), nota-se que não houve diferença significativa entre elas; porém foi obtida essa diferença nas formulações modificadas quimicamente (formulação FMQ) e fisicamente, pelo processo de pré-gelatinização (formulação FPG).

Quanto ao alongamento, a segunda formulação mais flexível foi a produzida com a fécula proveniente do estado do Paraná $(5,00 \pm 0,68 \mathrm{~mm})$, seguida daquela em que a fécula foi pré-gelatinizada $(4,96 \pm 0,54 \mathrm{~mm})$ e, por último - das espumas em que a fécula recebeu tratamento -, foi aquela em que houve o reaproveitamento das espumas $(4,30 \pm 0,54 \mathrm{~mm})$. Ao analisar os valores de alongamento das espumas sem tratamento da fécula (formulação F 57\%) e daquelas reaproveitadas (formulação REA) nota-se que não houve diferença significativa entre elas; porém, verificou-se diferença significativa de tais formulações com as demais espumas estudadas (formulações FPG, FOR e FMQ).

A FIG. 26 apresenta os resultados de resistência à tração e alongamento na ruptura das espumas contendo 10\% (a) e 100\% (b) de fécula de mandioca irradiada (modificação física), por radiação gama. As propriedades mecânicas de tais espumas estão mostradas em função da dose de irradiação. 

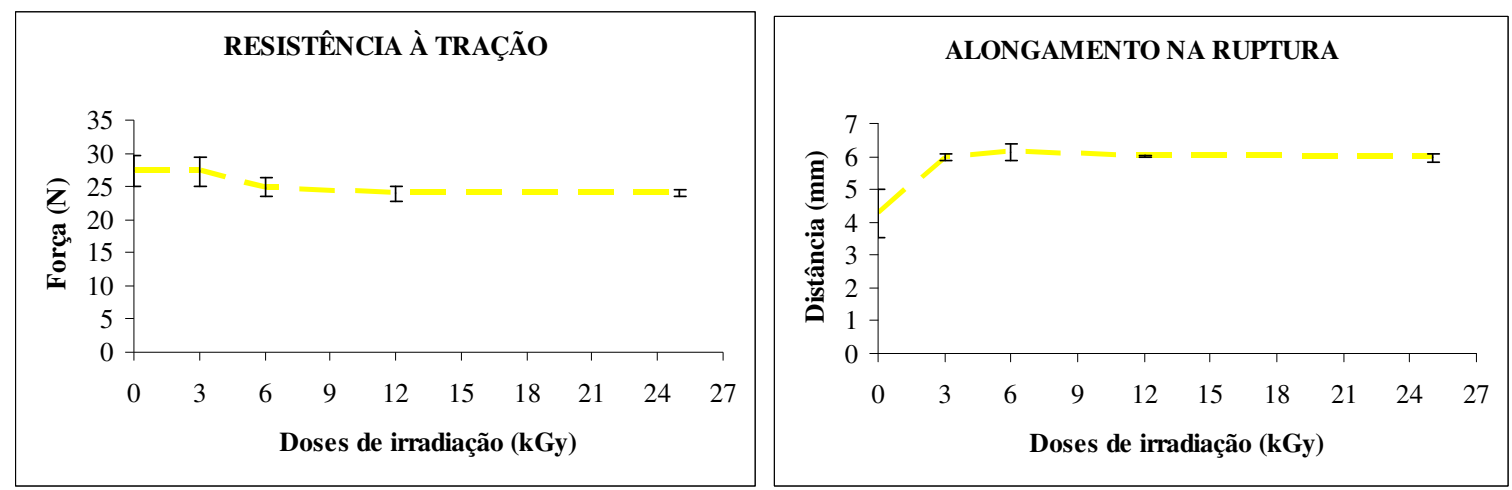

(a)
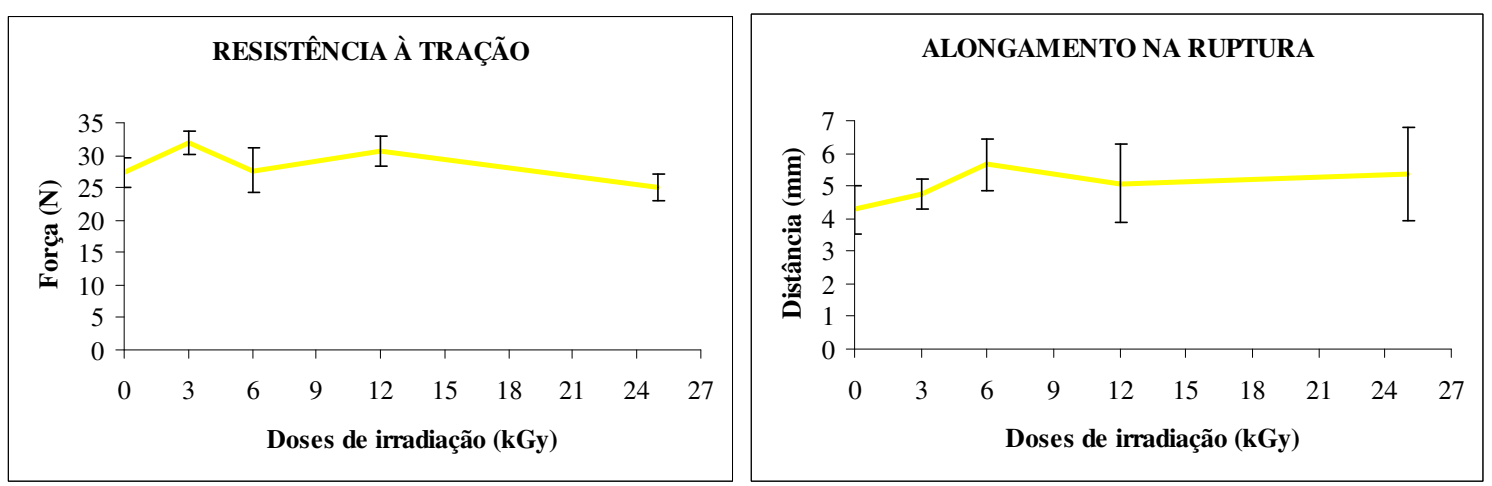

(b)

FIGURA 26 - Resistência à tração e alongamento na ruptura das espumas contendo 10\% (a) e $100 \%$ (b) de fécula de mandioca irradiada.

Na FIG. 26(a) nota-se que quando $10 \%$ da fécula de mandioca foi irradiada, a resistência das espumas à tração diminuiu com o aumento da dose, e o alongamento aumentou consideravelmente até à dose de $3 \mathrm{kGy}$ e depois se manteve praticamente constante nas doses de 6,12 e $25 \mathrm{kGy}$. Já para as espumas em que toda a fécula de mandioca foi irradiada (FIG. 26(b)), a resistência à tração se mostrou instável com o aumento da dose, e o alongamento aumentou até à dose de $6 \mathrm{kGy}$; porém, submetidas a doses maiores, o seu alongamento também se tornou instável. De acordo com Kober et al. (2007), a força de tração de plásticos contendo fécula de mandioca diminuiu com o aumento da dose de irradiação, alcançando uma redução de cerca de $11 \%$ à dose de 50 kGy. Segundo os autores, o aumento de açúcar redutor com o aumento da dose mostra a presença de $\alpha$ glucanos na gradual degradação, e essa redução do conteúdo polimérico (nas doses de 0 a $50 \mathrm{kGy}$ ) é mais evidente em amidos ricos em amilopectina predominante na fécula de mandioca. Para eles, a despolimerização do amido ocorreu 
como resultado da irradiação, originando cadeias lineares e ramificadas de baixo peso molecular. As forças obtidas das espumas para doses de irradiação de 3, 6, 12 e 25 kGy em $10 \%$ da fécula foram, respectivamente: $27,3 \pm 2,2 \mathrm{~N}$ (formulação FI3), $24,9 \pm 1,4 \mathrm{~N}$ (formulação FI6), 23,9 \pm 1,2 N (formulação FI12) e 23,9 \pm 0,5 N (formulação FI25), e em $100 \%$ da fécula foram respectivamente: $31,9 \pm 1,7 \mathrm{~N}$ (formulação FI3), 27,6 \pm 3,5 N (formulação FI6), 30,6 \pm 2,3 N (formulação FI12) e 24,9 \pm 2,0 N (formulação FI25). De acordo com a análise estatística (ANOVA), quando 10\% da fécula foi irradiada (FIG. 26(a)), as forças correspondentes às doses de 0 e 3 kGy não variaram significativamente entre si, assim como para as doses de 12 e 25 kGy. Já a força obtida da espuma com $10 \%$ de fécula irradiada a $6 \mathrm{kGy}$ diferiu significativamente de todas as formulações estudadas. Todas as espumas em que $100 \%$ da fécula foi irradiada (FIG. 26(b)) tiveram diferença significativa $(\mathrm{p}>0,05)$ no parâmetro força. Em relação ao alongamento, as espumas com $10 \%$ da fécula irradiada às doses de 3, 6, 12 e $25 \mathrm{kGy}$ obtiveram, respectivamente,

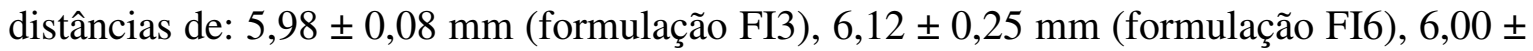
$0,03 \mathrm{~mm}$ (formulação FI12) e 5,96 \pm 0,12 mm (formulação F25) - não havendo diferença significativa entre elas - , e com $100 \%$ da fécula obtiveram respectivamente: 4,75 $\pm 0,45$ mm (formulação FI3), 5,66 \pm 0,79 mm (formulação FI6), 5,07 \pm 1,21 mm (formulação FI12) e 5,37 $\pm 1,43 \mathrm{~mm}$ (formulação FI25). Todos os valores de distância encontrados para as formulações em que $100 \%$ da fécula foi irradiada (FIG. 26(b)) tiveram diferença significativa $(p>0,05)$ entre eles.

Os resultados dos testes de perda de produção (representada em \%), da quantidade média de massa necessária para formar uma embalagem (espuma completa), da densidade e da absorção de água (representada em \%) das espumas com diferentes tratamentos modificações química e físicas (pré-gelatinização e irradiação) da fécula de mandioca, estão apresentados na TAB. 5. 
TABELA 5 - Resultados da quantidade média de massa necessária para formar uma embalagem (espuma), da perda de produção, da densidade e da solubilidade das espumas sem e com diferentes tratamentos da fécula de mandioca e do isopor.

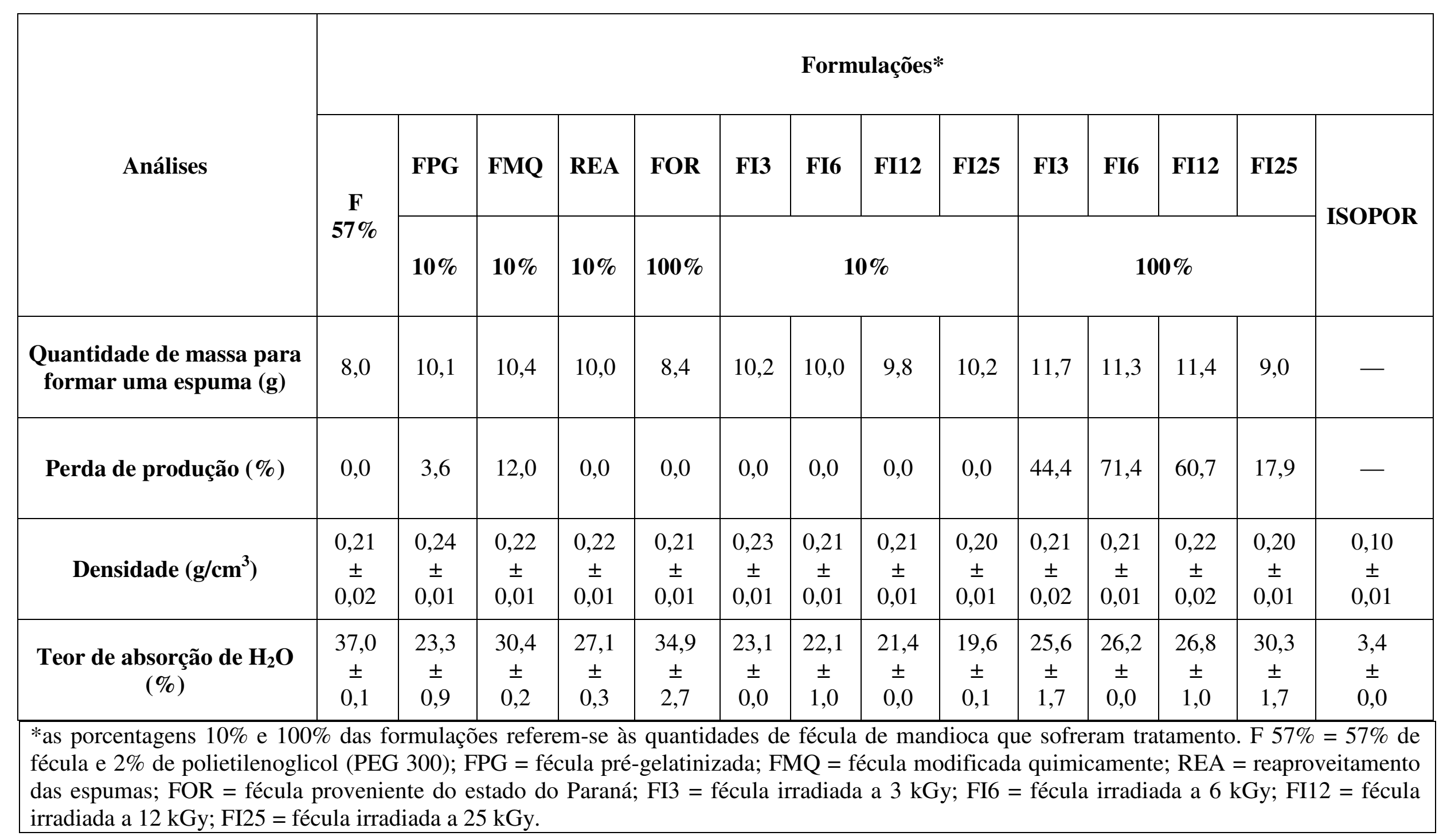


Na TAB. 5 pode-se observar que a espuma em que a fécula não sofreu tratamento (formulação F 57\%) foi a que precisou de menor quantidade de massa para formar uma espuma completa (sem bolhas e rachaduras), enquanto a quantidade de massa aumentou para aquelas com modificações química (FMQ) e físicas (FPG e FI), aquelas produzidas com a fécula do estado do Paraná (FOR), e também para as produzidas com matéria-prima reciclada (REA).

As espumas em que $100 \%$ da fécula foi irradiada, foram as que necessitaram de mais massa para formar uma espuma completa - com exceção daquela irradiada à $25 \mathrm{kGy}$ (formulação FI25) -, sendo que a irradiada à dose de 3 kGy (formulação FI3) foi a que precisou de mais massa para formar uma espuma completa (sem bolhas e rachaduras). Para as espumas em que $10 \%$ da fécula foi pré-gelatinizada (formulação FPG), modificada quimicamente (formulação FMQ) e irradiada (formulações FI), além daquela em que se utilizou $100 \%$ de fécula proveniente do estado do Paraná (formulação FOR), as quantidades de massa requeridas para formar uma espuma completa foram cerca de 10,0 g. Já as espumas sem tratamento da fécula (formulação F 57\%) e com diferente fornecedor (proveniente do estado do Paraná - formulação FOR) precisaram de praticamente a mesma quantidade de massa: em torno de $8,00 \mathrm{~g}$.

Quanto às perdas de produção, as formulações em que toda a fécula foi irradiada (formulações FI) foram as de pior produtividade, seguidas daquela em que $10 \%$ da fécula foram modificadas quimicamente (formulação FMQ) e, por fim, daquela em que $10 \%$ da fécula foram modificadas fisicamente (formulação FPG). As demais formulações mostraram excelente produtividade, sem perda de produção.

A densidade das espumas variou de 0,20 a $0,24 \mathrm{~g} / \mathrm{cm}^{3}$, sendo que a espuma em que a fécula foi pré-gelatinizada (formulação FPG) mostrou ser a mais densa de todas as estudadas, enquanto que as espumas em que a fécula foi irradiada a dose de $25 \mathrm{kGy}$ (formulações FI25) foram as menos densas.

Com relação à absorção de água, as espumas fabricadas com (a) fécula de mandioca modificada física e quimicamente, (b) matéria-prima reciclada (espumas trituradas) e (c) fécula proveniente do estado do Paraná, absorveram menos água do que as fabricadas com fécula de mandioca não modificada, do estado da Bahia. De acordo com Shogren (1996), Adebowale et al. (2006) e Guan e Hanna (2006) a acetilação (modificação química) dos grupos hidroxilas do amido aumenta a hidrofobicidade e, consequentemente, a resistência do amido à água. Dos tratamentos dados à fécula, a espuma que menos absorveu água foi a que $10 \%$ da fécula foi irradiada à dose de $25 \mathrm{kGy}$ (formulação FI25). Como pode ser 
observado na TAB. 5, quanto maior a quantidade de fécula irradiada na formulação (formulações FI de 100\%), maior a absorção de água pelas espumas.

Com base nos resultados obtidos até aqui, foi decidido dar continuidade aos estudos com a formulação contendo $57 \%$ de fécula de mandioca da Companhia Lorenz (estado do Paraná) - sendo $10 \%$ desta fécula modificada fisicamente (fécula pré-gelatinizada) - gel e polietilenoglicol (PEG 300) como plastificante (2\% em peso dos sólidos). Isso porque a formulação com: (a) $57 \%$ de fécula mostrou ser mais resistente à tração do que aquela com $55 \%$ de fécula; (b) fécula de mandioca proveniente do estado do Paraná (Lorenz), apesar de ter praticamente as mesmas propriedades mecânicas e de barreira daquela do estado da Bahia (Flor de Lótus), apresentou melhor aspecto visual (espuma mais branca assemelhando-se à embalagem de poliestireno expandido (isopor)); (c) 10\% de fécula prégelatinizada obteve excelentes resultados de resistência à tração e alongamento, de absorção de água e de produtividade; e (d) o plastificante polietilenoglicol (PEG 300) mostrou baixa solubilidade em água, boa resistência mecânica e estabilidade durante a produção das espumas.

\subsubsection{Estudo da Avaliação do Ciclo de Vida (ACV)}

A Avaliação do Ciclo de Vida abrange aplicações automobilísticas, de construção, eletrônicas, químicas, têxteis, de embalagens e em uma série de outros setores (Baumann e Tillman, 2004; Guineé, 2002; Narayan, 2004). Na indústria de embalagens vários estudos têm sido feitos para comparar embalagens utilizadas em diferentes aplicações, sendo as embalagens de alimentos uma delas (Madival et al., 2009).

Neste trabalho, um estudo de ACV prático foi realizado com o objetivo de comparar dois processos para obtenção das embalagens de fécula de mandioca tipo espuma. Um estudo de Avaliação do Ciclo de Vida poderia ser inacabável pela sua extensão e abrangência de informações. Assim, para um estudo de ACV prático devem ser estabelecidos fronteiras ou limites do sistema a ser estudado. O sistema é representado pelo conjunto de subsistemas ou processos unitários que constitui o ciclo de vida do produto (Mourad et al., 2002). As principais etapas do ciclo de vida das espumas de fécula de mandioca, obtidas pelos processos de termoprensagem e extrusão, e as fronteiras dos sistemas de estudo são mostradas nas FIG. 27 e 28, respectivamente. 


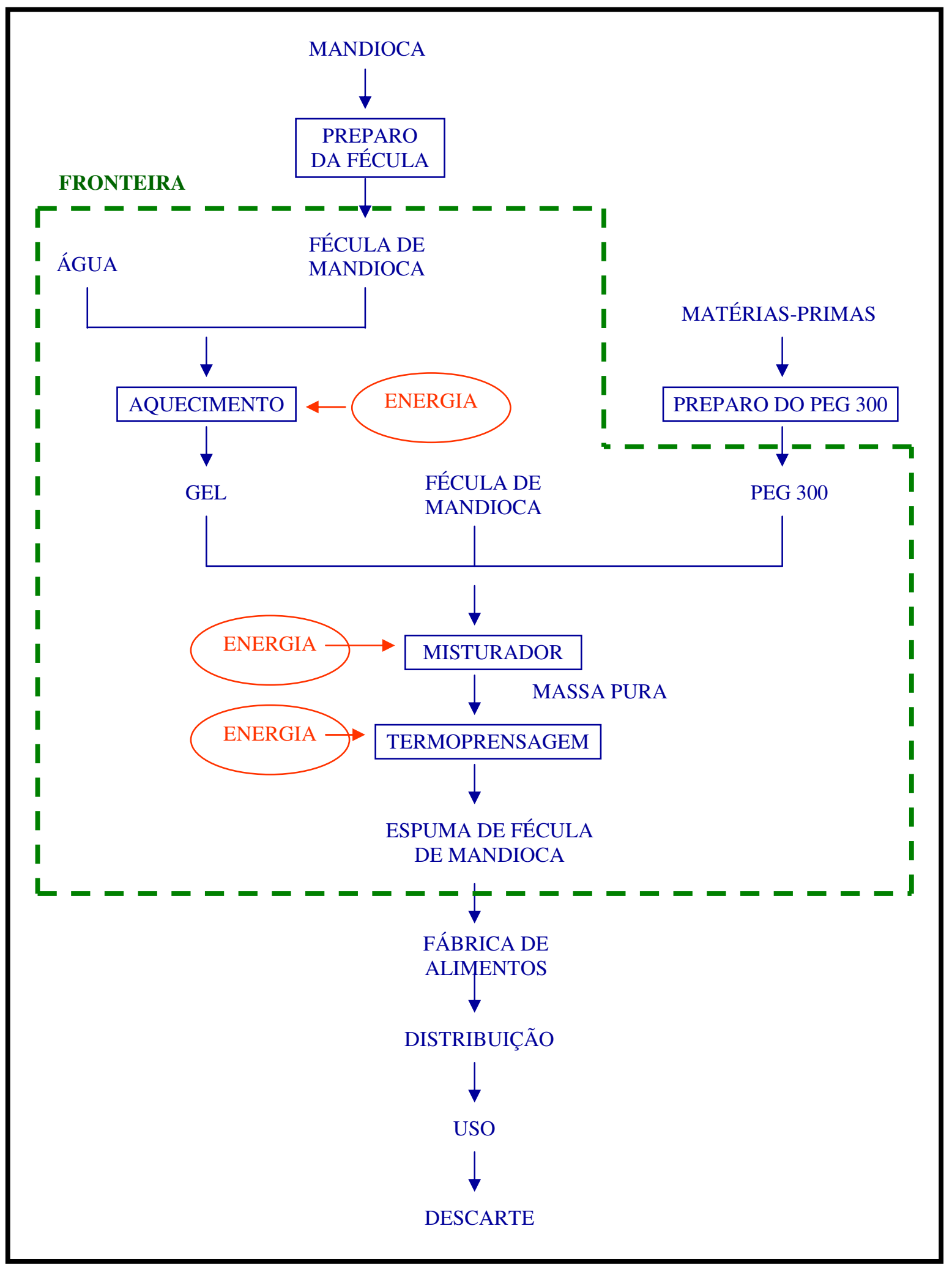

FIGURA 27 - Principais etapas do ciclo de vida das espumas de fécula de mandioca, obtidas por termoprensagem, e sua fronteira de estudo. 


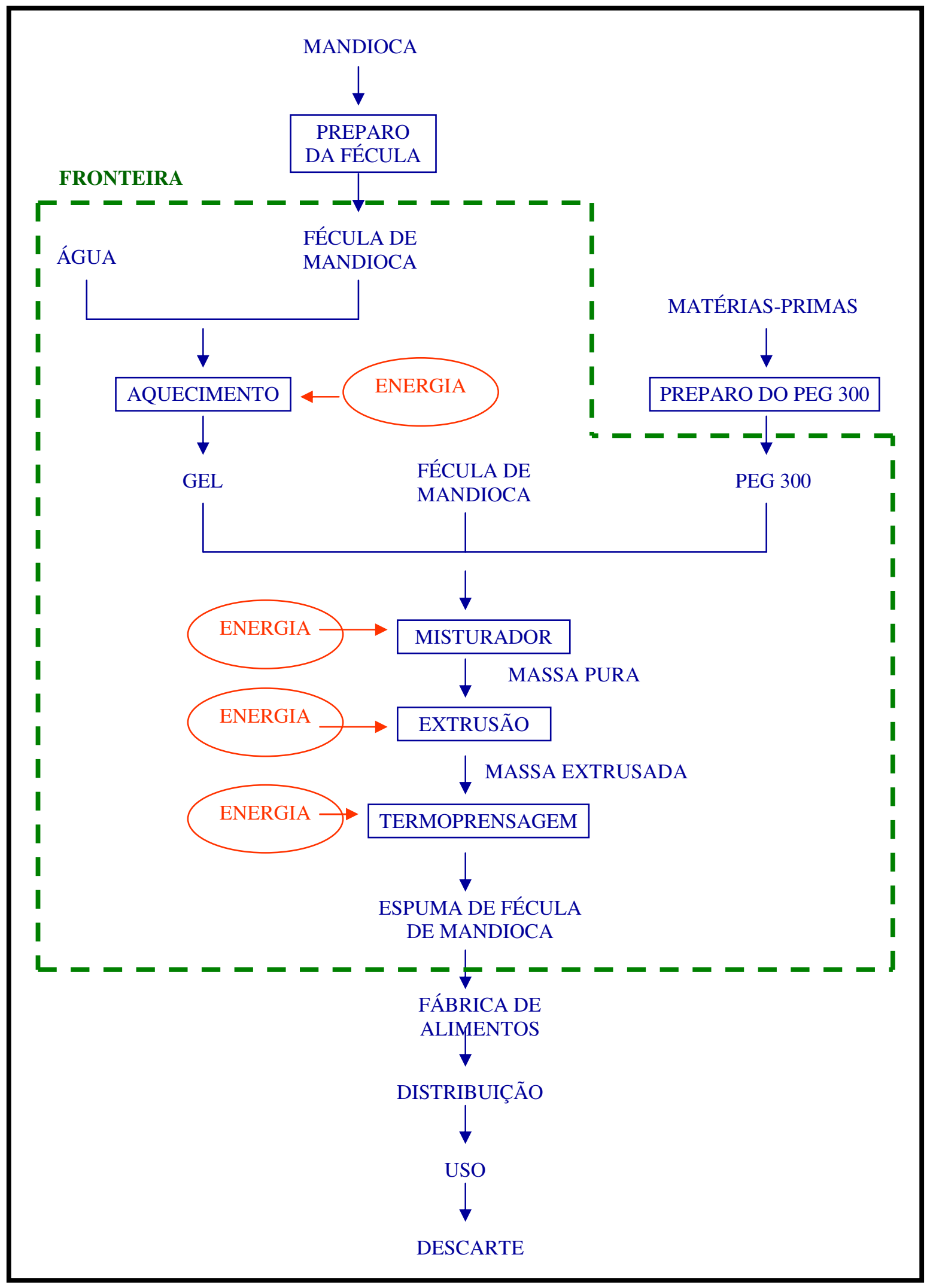

FIGURA 28 - Principais etapas do ciclo de vida das espumas de fécula de mandioca, obtidas por extrusão seguida de termoprensagem, e sua fronteira de estudo. 
Verifica-se nas FIG. 27 e 28 que as fronteiras estabelecidas do sistema se limitam aos processos - termoprensagem e extrusão seguida de termoprensagem - de obtenção das espumas (embalagens) de fécula de mandioca. Os resultados e as conclusões de um estudo de ACV estão diretamente relacionados à fronteira selecionada e às considerações definidas no objetivo e escopo do trabalho, como por exemplo, a unidade funcional (UF), a decisão de incluir ou não investimentos capitais, etc (Mourad et al., 2002). Para definir a unidade funcional do estudo de ACV deste projeto tomou-se como base a função da embalagem, como por exemplo, a de acondicionar alimentos (maçãs) para distribuição até o consumidor. Logo, a UF definida foi a de embalar $60 \mathrm{~kg}$ de maçãs.

Em seguida, calculamos o fluxo de referência para cada processo. Fluxo de referência (FR) é a quantidade de produto (embalagem) necessária para cumprir a unidade funcional (UF). Considerando que uma maçã pesa em média $0,170 \mathrm{~kg}$, temos que:

(a) para o processo de termoprensagem:

- cada embalagem pesa $0,027 \mathrm{~kg}$

1 embalagem ------ 0,027 kg ------ 6 maçãs ------ 1 kg maçãs

X embalagens ---------------------------------------- 60 kg maçãs (UF)

$X=60$ embalagens (aproximadamente)

1 embalagem ------ $0,027 \mathrm{~kg}$

60 embalagens ------ Y kg

$\mathrm{Y}=1,620 \mathrm{~kg}$ de embalagem

Logo, o fluxo de referência para o processo de termoprensagem é 1,620 kg / 60 .

(b) para o processo de extrusão:

- cada embalagem pesa $0,028 \mathrm{~kg}$ 
1 embalagem ------ 0,028 kg ------ 6,2 maçãs ------ 1,054 kg maçãs

X embalagens $60 \mathrm{~kg}$ maçãs (UF)

$X=57$ embalagens (aproximadamente)

1 embalagem ------ $0,028 \mathrm{~kg}$

57 embalagens ------ Y kg

$\mathrm{Y}=1,596 \mathrm{~kg}$ de embalagem

Logo, o fluxo de referência para o processo de extrusão é 1,596 kg / 57.

Definidos os fluxos de referências, fez-se a Análise de Inventário, porém de maneira muito simples. Ou seja, foram coletados os principais dados referentes às entradas (consumo de fécula de mandioca, água, PEG 300 e de energia) e saídas (vapor de água) das etapas incluídas nas fronteiras do estudo de ACV nos dois processos. Os resultados de Análise de Inventário dos processos de termoprensagem (A) e de extrusão (B) e sua relação (B/A) estão apresentados na TAB. 6.

TABELA 6 - Análise de Inventário dos dois processos de obtenção das embalagens (espumas) e a relação entre ambos.

\section{Termoprensagem Extrusão}

(A)

(B)

B/A (\%)

\section{Fluxo de Referência}

(kg de embalagem /

$1,620 / 60$

$1,596 / 57$

$0,985 / 0,95$

quantidade de embalagem)

\begin{tabular}{lccc}
\hline \multicolumn{1}{c}{ Entradas } & & & \\
\hline Fécula de mandioca $(\mathrm{kg})$ & 1,638 & 1,091 & 0,666 \\
Água $(\mathrm{kg})$ & 1,045 & 0,978 & 0,936 \\
PEG 300 $(\mathrm{kg})$ & 0,005 & 0,004 & 0,800 \\
Energia $(\mathrm{kWh})$ & 28,116 & 211,800 & 7,533 \\
\hline \multicolumn{1}{c}{ Saídas } & & & \\
\hline Água (vapor) & 1,068 & 0,844 & 0,790 \\
\hline
\end{tabular}


Verifica-se, a partir da TAB. 6, que o processo de extrusão requer menos embalagens do que o processo de termoprensagem para acondicionar $60 \mathrm{~kg}$ de alimento (maçãs). Isso ocorre, pois as embalagens (espumas) de fécula de mandioca produzidas por extrusão são mais resistentes do que aquelas obtidas por termoprensagem - e quanto mais resistentes, mais peso e/ou quantidade de alimento suportam. Consequentemente, o consumo de fécula de mandioca, água e PEG 300 (plastificante) no processo de extrusão também é menor em relação ao outro processo. Como já era esperado, o consumo de energia no processo de extrusão é maior do que o de termoprensagem, por ter uma etapa a mais no ciclo de vida das embalagens, ou seja, devido à energia consumida pela extrusora mono rosca.

\subsubsection{Produção das embalagens ativas de fécula de mandioca tipo espuma}

\subsubsection{Adição de agentes ativos à massa}

Os frutos minimamente processados apresentam tempo de prateleira menor do que os frutos intactos, pois sofrem estresse devido às lesões ocorridas durante o período de preparo (descasque e corte), acelerando o metabolismo como resultado da destruição da compartimentação de enzimas e substratos, além de proporcionar o escurecimento da fruta (Bonnas et al., 2003; Kluge et al., 2003 e Sarzi e Durigan, 2002). Existem algumas maneiras de contornar esses problemas, tais como: adição de agentes que evitem o escurecimento enzimático, a proliferação de fungos e a perda de peso; a utilização de filmes plásticos que modifiquem a atmosfera a que as frutas estarão submetidas, e o armazenamento das frutas a temperaturas baixas (Lima et al., 2005). O objetivo neste item do trabalho foi testar embalagens ativas de fécula de mandioca para armazenar frutos de banana e mamão.

Cloreto de cálcio, sorbato de potássio, permanganato de potássio e ácido 1ascórbico foram adicionados separadamente às espumas de fécula de mandioca, formuladas com $57 \%$ de fécula de mandioca em pó e $2 \%$ de plastificante polietilenoglicol (PEG 300) - tudo para evitar perda de qualidade do produto embalado, tendo cada ativo uma função característica sobre o alimento. O cloreto de cálcio evita a perda de peso do alimento embalado; o sorbato de potássio evita a proliferação dos fungos no alimento; o permanganato de potássio atua como absorvedor de etileno (gás associado ao escurecimento da fruta); e o ácido l-ascórbico evita o escurecimento da fruta dentro da embalagem. 
As funções dos agentes ativos nas espumas serão apresentadas nos resultados dos testes sensoriais (item 5.1.5.3).

O aspecto visual das espumas com cloreto de cálcio, sorbato de potássio, permanganato de potássio e ácido l-ascórbico está apresentado na FIG. 29.

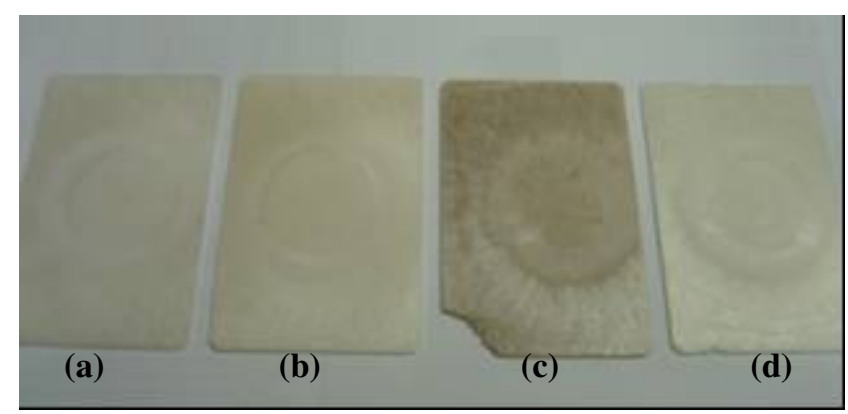

FIGURA 29 - Aspecto visual das espumas de fécula de mandioca com cloreto de cálcio (a), sorbato de potássio (b), permanganato de potássio (c) e ácido l-ascórbico (d).

As espumas contendo os agentes ativos em diferentes concentrações (5\%, $10 \%$ e $15 \%$ ) e métodos de adição, também foram submetidas a ensaios mecânicos (tração e alongamento) e de barreira (absorção de água) para verificar se a adição destes ativos e a maneira como foram adicionados alteraram as propriedades mecânicas e de barreira das espumas. Para efeito de comparação, determinamos a força de tração e o alongamento das espumas sem a adição de ativos (formulação SAA). Os resultados de resistência à tração e alongamento na ruptura das espumas estão apresentados na FIG. 30 para as espumas contendo diferentes concentrações de ativos adicionados à massa pelo método 1 (sem a incorporação dos ativos no gel - ver metodologia) e, FIG. 31, para as espumas contendo $15 \%$ de ativos adicionados à massa pelo método 2 (com a incorporação dos ativos no gel ver metodologia). 


\section{RESISTÊNCIA À TRAÇÃo}

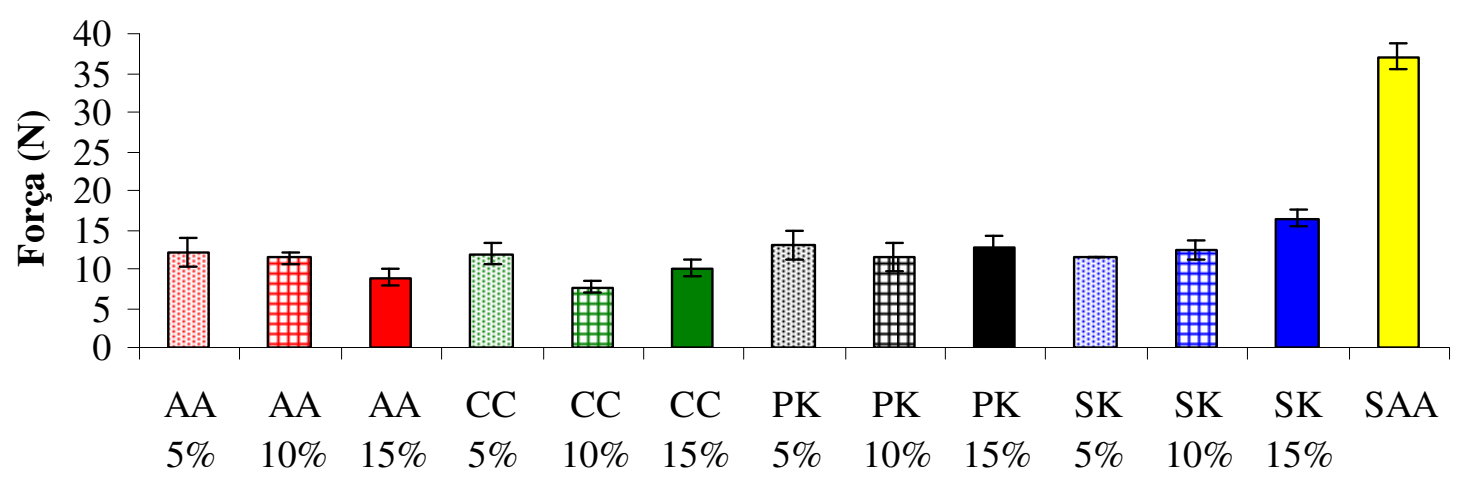

Formulações

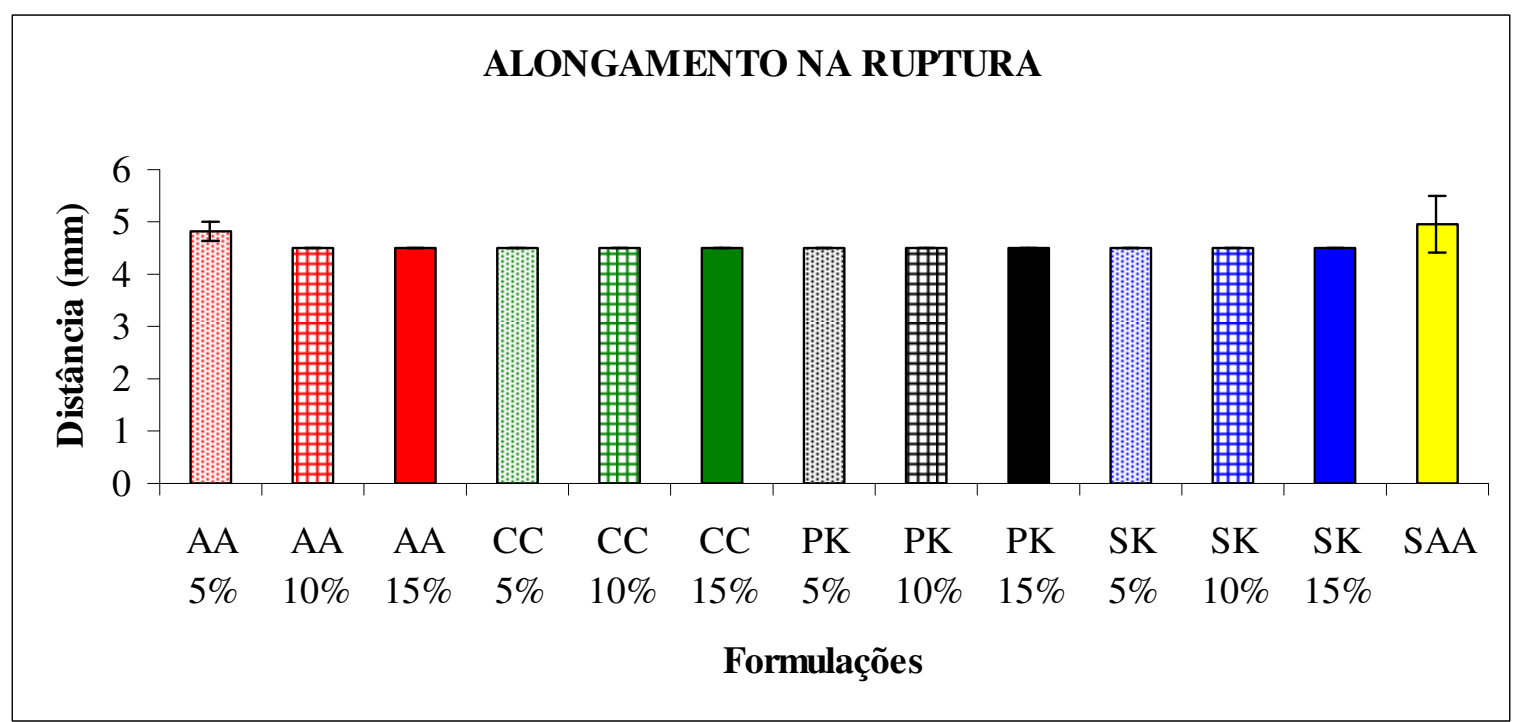

FIGURA 30 - Resistência à tração e alongamento na ruptura das espumas de fécula de mandioca sem ativos e com diferentes concentrações de ativos, não incorporados ao gel (método 1). $\mathrm{AA}=$ ácido ascórbico; $\mathrm{CC}=$ cloreto de cálcio; $\mathrm{PK}=$ permanganato de potássio; $\mathrm{SK}=$ sorbato de potássio; SAA = espumas sem adição de ativos.

A adição de agentes ativos às espumas de fécula de mandioca pelo método 1 (ativos não incorporados ao gel) não contribuiu para uma melhora de suas propriedades mecânicas. Ou seja, os resultados de resistência à tração e alongamento das formulações contendo ativos foram inferiores aos resultados das espumas sem esses ativos (formulação SAA: $37,0 \pm 1,7 \mathrm{~N}$ e 4,96 $\pm 0,54 \mathrm{~mm}$ ). A estrutura física das espumas de fécula de mandioca depende da formação de uma rede polimérica de moléculas de amilose e amilopectina. Todos os ativos utilizados neste estudo não contribuíram para o 
estabelecimento de uma rede polimérica, funcionando como cargas inertes e, assim, prejudicando as propriedades mecânicas das espumas.

Dos ativos estudados, o sorbato de potássio, na concentração de $15 \%$ (formulação SK $15 \%)$, foi o que proporcionou maior resistência à tração $(16,5 \pm 0,9 \mathrm{~N})$ - diferindo significativamente $(\mathrm{p}>0,05)$ das demais espumas - , seguido do permanganato de potássio a $5 \%(12,9 \pm 1,8 \mathrm{~N})$ e $15 \%(12,6 \pm 1,8 \mathrm{~N})$ - formulações PK 5\% e PK 15\%, respectivamente. A espuma contendo $10 \%$ de cloreto de cálcio (formulação CC 10\%) foi a menos resistente $(7,7 \pm 0,7 \mathrm{~N})$. As demais espumas ativas apresentaram forças de: 8,9 $\pm 1,2 \mathrm{~N}$ (formulação AA 15\%), 10,1 $\pm 1,1 \mathrm{~N}$ (formulação CC 15\%), 11,4 \pm 0,7 N (formulação AA 10\%), 11,4 \pm 0,1 N (formulação SK 5\%), 11,5 \pm 1,8 N (formulação PK 10\%), 11,9 \pm 1,3 N (formulação CC 5\%), 12,1 $\pm 1,7 \mathrm{~N}$ (formulação AA 5\%) e 12,3 $\pm 1,2 \mathrm{~N}$ (formulação SK 10\%). Praticamente todas as espumas contendo ativos (ácido ascórbico, cloreto de cálcio, permanganato de potássio e sorbato de potássio), nas três concentrações estudadas, obtiveram o mesmo alongamento (em torno de 4,50 $\mathrm{mm}$ ) - exceto aquela formulada com $5 \%$ de ácido ascórbico (formulação AA 5\%) que apresentou alongamento maior $(4,82$ $\mathrm{mm}$ ), semelhante ao alongamento da formulação sem ativos (formulação SAA). Os valores de força e distância obtidos pelas espumas ativas variaram significativamente daqueles obtidos pela espuma sem ativos (formulação SAA). 

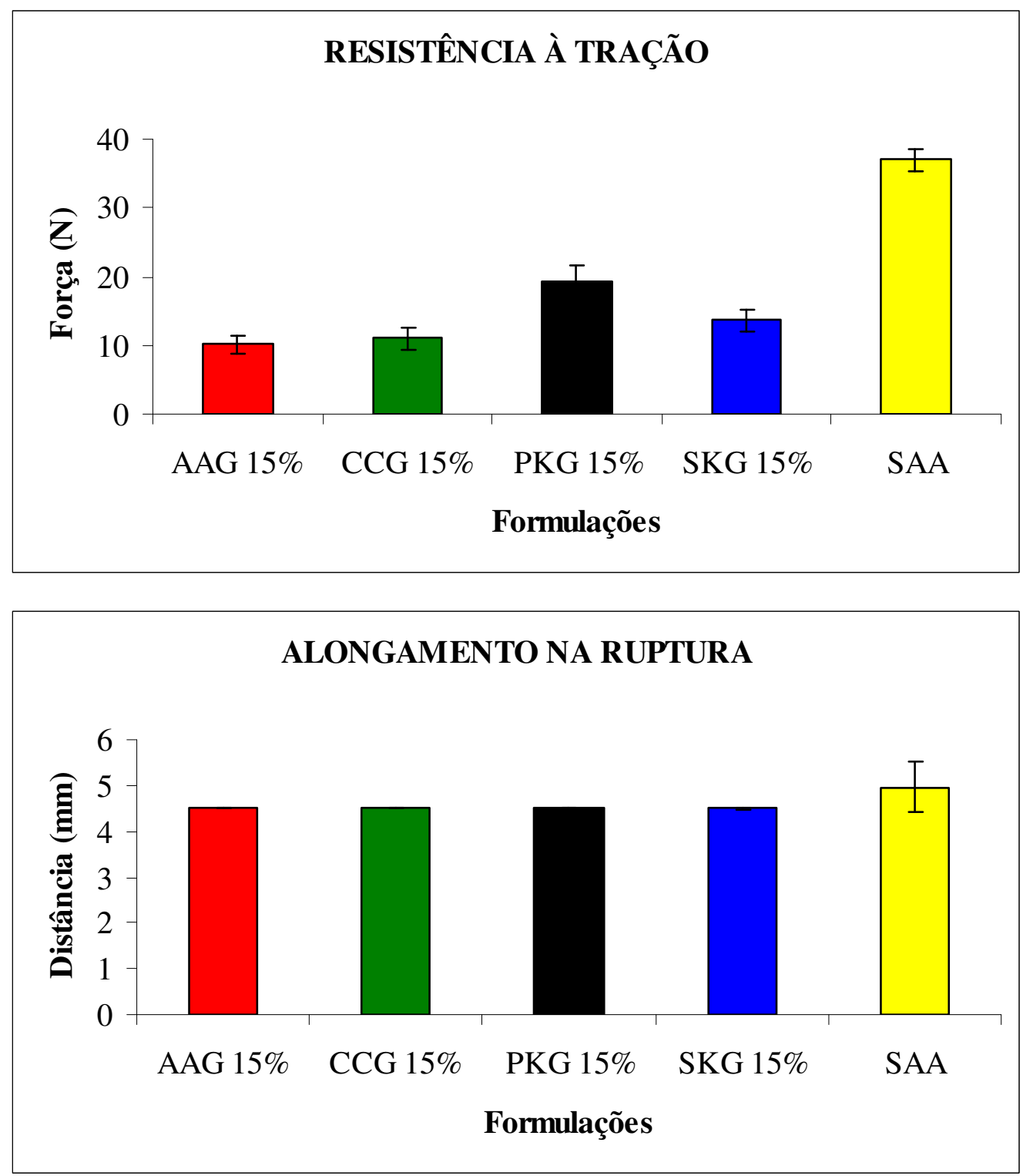

FIGURA 31 - Resistência à tração e alongamento na ruptura das espumas de fécula de mandioca sem ativos e contendo ativos na concentração de $15 \%$, incorporados ao gel (método 2). AAG 15\% = 15\% de ácido ascórbico incorporado ao gel; CCG 15\% =15\% de cloreto de cálcio incorporado ao gel; PKG 15\% = 15\% de permanganato de potássio incorporado ao gel; SKG 15\% = 15\% de sorbato de potássio incorporado ao gel; SAA = espumas sem adição de ativos.

Assim como pelo método 1 , a adição de agentes ativos às espumas de fécula de mandioca pelo método 2 (incorporação dos ativos - na concentração de $15 \%$ - ao gel) não resultou em melhora de suas propriedades mecânicas com relação às espumas produzidas sem ativos. A espuma com permanganato de potássio (formulação PKG 15\%) apresentou maior resistência à tração $(19,2 \pm 2,3 \mathrm{~N})$, enquanto que a formulada com ácido ascórbico 
(formulação AAG 15\%) foi a menos resistente $(10,1 \pm 1,3 \mathrm{~N})$. As espumas contendo cloreto de cálcio (formulação CCG 15\%) e sorbato de potássio (formulação SKG 15\%) resistiram, respectivamente, às forças de $11,0 \pm 1,6 \mathrm{~N}$ e 13,6 \pm 1,7 N. De acordo com a análise estatística (ANOVA), não houve diferença significativa entre as espumas com cloreto de cálcio (formulação CCG 15) e ácido ascórbico (formulação AAG 15), porém tais espumas diferiram significativamente das demais espumas. Todas as espumas contendo os ativos adicionados pelo segundo método obtiveram o mesmo alongamento $(4,49 \mathrm{~mm})$ - não havendo diferença significativa entre elas -, sendo esta menor do que a da espuma sem ativos (formulação SAA - 4,96 $\pm 0,54 \mathrm{~mm}$ ). Os valores de força e distância das espumas sem ativos (formulação SAA) foram significativamente diferentes daqueles obtidos pelas espumas ativas.

Na TAB. 7 estão apresentados os resultados da quantidade média de massa necessária para formar uma embalagem (espuma), da perda de produção, da densidade e da solubilidade das espumas sem e com agentes ativos, em diferentes concentrações, adicionados à massa por ambos os métodos estudados. 
TABELA 7 - Resultados da quantidade média de massa necessária para formar uma embalagem (espuma), da perda de produção, da densidade e da solubilidade das espumas sem e com agentes ativos, em diferentes concentrações, adicionados à massa por ambos os métodos estudados.

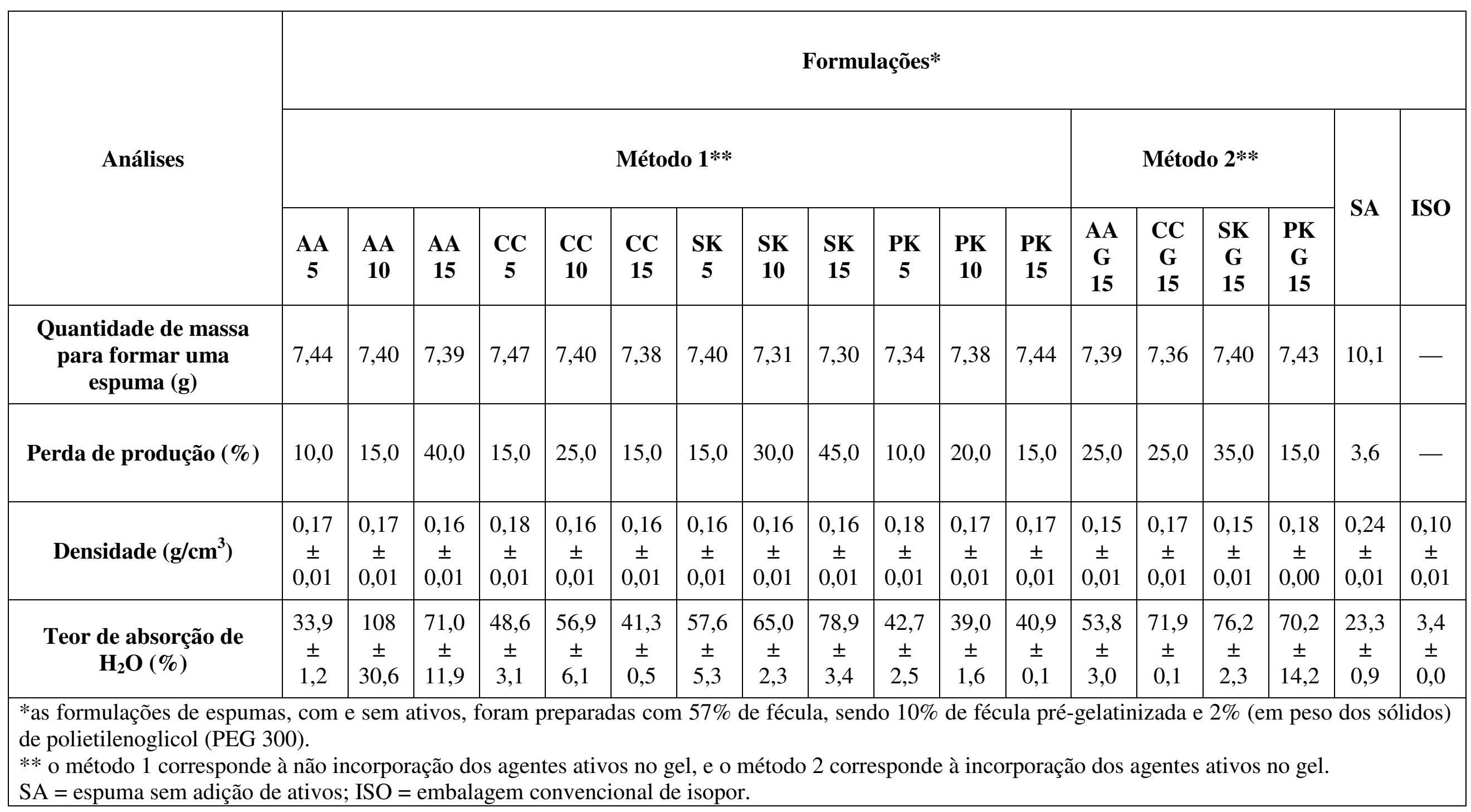


Nota-se, na TAB. 7, que as quantidades de massa para formar as espumas contendo os agentes ativos, nas diferentes concentrações e em ambos os métodos estudados, foram praticamente as mesmas - em torno de 7,38g - sendo estas, menores em relação à massa necessária para formar uma espuma sem ativos (formulação SA - em torno de 10,1g, TAB. 7). Ao comparar as massas obtidas pelos dois métodos utilizados para as formulações contendo $15 \%$ de ativos, verifica-se que a incorporação dos ativos no gel (método 2) pouco influenciou as quantidades de massa para a obtenção das espumas ativas. Com exceção do permanganato de potássio (formulações PK 5, PK 10 e PK 15), quanto maior a concentração de ativos, menor a quantidade de massa para a produção das espumas.

A adição de ativos às espumas provocou maior perda de produção - 10,0\% a $45,0 \%$ - em relação àquela formulada sem ativos (formulação SA, ver TAB. 7). As espumas com 5\% de ácido ascórbico (formulação AA 5) e 5\% de permanganato de potássio (formulação PK 5) mostraram melhor produtividade, enquanto que a composta por $15 \%$ de sorbato de potássio (formulação SK 15) foi a de pior produtividade. A incorporação de $15 \%$ dos ativos no gel (método 2) diminuiu a perda de produção das espumas contendo ácido ascórbico (formulação AAG 15) e sorbato de potássio (formulação SKG 15), porém aumentou a perda de produção daquelas contendo cloreto de cálcio (formulação CCG 15) - a incorporação de $15 \%$ de permanganato de potássio (formulação PKG 15) no gel não influenciou a produtividade da espuma.

Quanto à densidade, as espumas com os ativos, nas diferentes concentrações e em ambos os métodos utilizados, apresentaram densidades muito próximas, variando de 0,15 $\mathrm{g} / \mathrm{cm}^{3}$ a $0,18 \mathrm{~g} / \mathrm{cm}^{3}$. Pode-se dizer que o uso do segundo método de adição dos ativos nada influenciou nas densidades das espumas. A espuma sem ativos (formulação SA) mostrou ser um pouco mais densa do que as espumas contendo ativos.

Verifica-se, ainda na TAB. 7, que a adição de ativos às espumas não contribuiu para suas propriedades de barreira, provavelmente porque os ativos são sais, que absorvem muita água. Todas as espumas contendo ativos absorveram mais água do que aquelas sem ativos (formulação SA), sendo a adição de 10\% de ácido ascórbico, não incorporado ao gel (formulação AA 10), responsável por elevada absorção de água pela espuma - a que mais absorveu água. Em contrapartida, a adição de 5\% de ácido ascórbico, não incorporado ao gel (formulação AA 5), fez com que a espuma absorvesse menos água em relação às formulações contendo ativos. Observa-se que para as espumas formuladas com sorbato de potássio e permanganato de potássio, produzidas pelo método 1 , quanto maior a 
concentração de ativo maior a absorção de água; porém, para aquelas formuladas com ácido ascórbico e cloreto de cálcio, isso não ocorre. Assim como foi observado na TAB. 5, a TAB. 7 mostra que a embalagem convencional de isopor (poliestireno expandido) continua sendo a embalagem que menos absorve água, ou seja, absorve muito pouca água em relação às espumas de fécula de mandioca.

As espumas contendo $15 \%$ de sorbato de potássio e $15 \%$ de permanganato de potássio, incorporados ou não ao gel (métodos 1 e 2), apesar de absorverem elevada quantidade de água mostraram ser as mais resistentes à tração dentre as espumas formuladas com agentes ativos.

As FIG. 32 e 33 mostram, respectivamente, o teor de umidade e a perda de massa das espumas sem ativos (formulação SAA) e daquelas contendo, separadamente, $15 \%$ de sorbato de potássio e $15 \%$ de permanganato de potássio, adicionados à massa por ambos os métodos estudados (formulações SK 15, SKG 15, PK 15 e PKG 15) - ao longo dos dias sem controle de temperatura e umidade (a) e com controle de temperatura e umidade (b). 


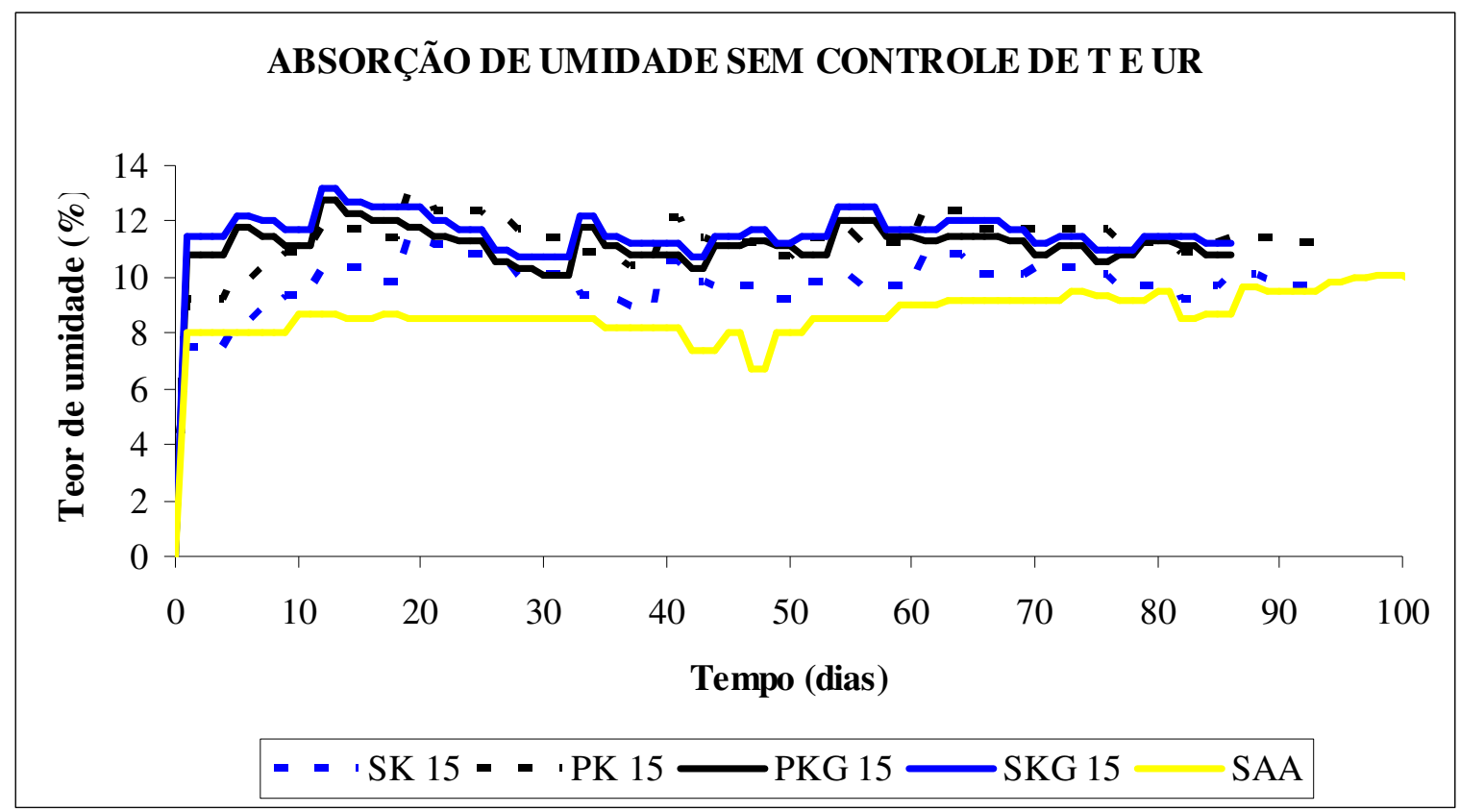

(a)

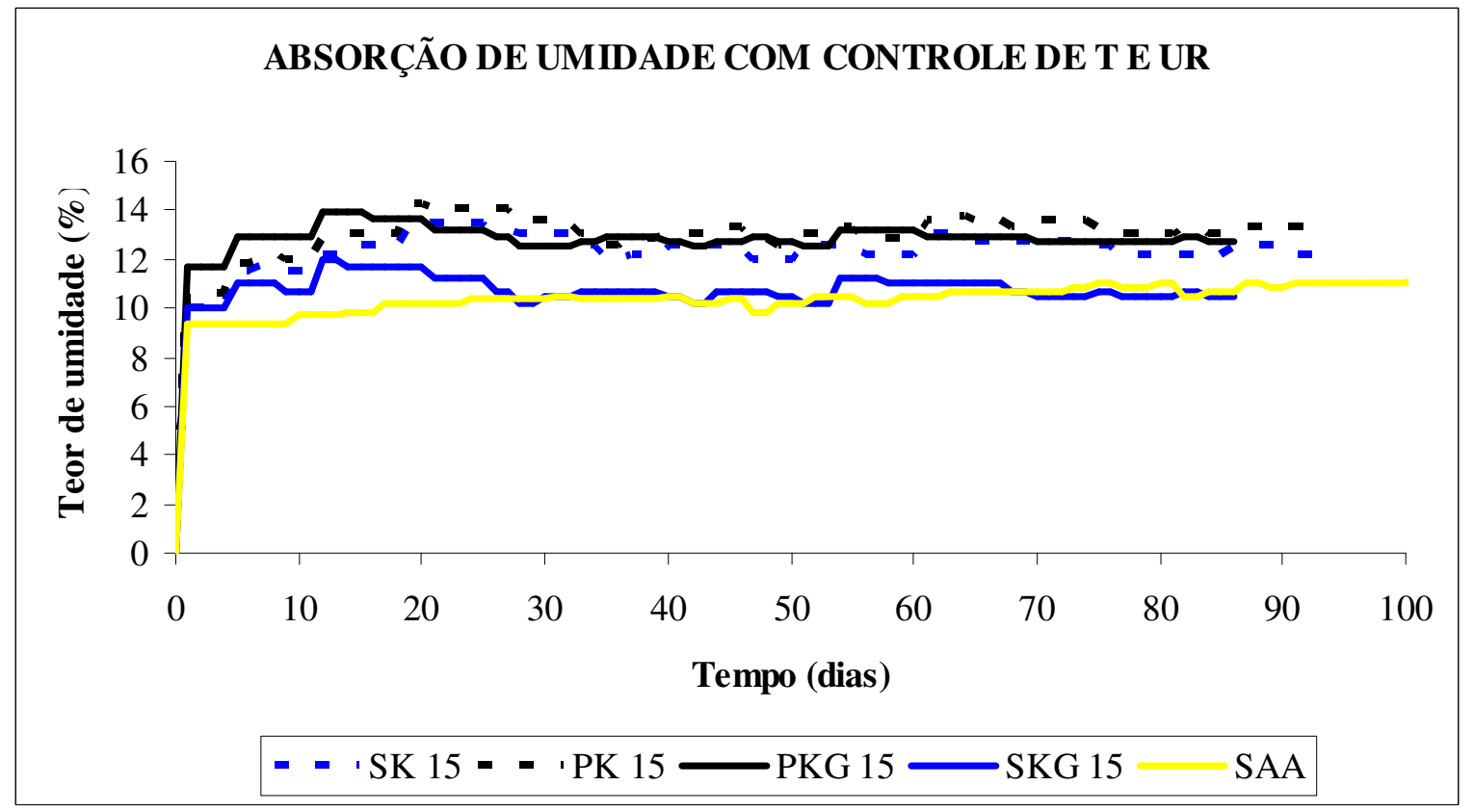

(b)

FIGURA 32 - Teor de umidade das espumas de fécula de mandioca sem e com $15 \%$ de agentes ativos, adicionados à massa pelos métodos 1 (ativos não incorporados ao gel) e 2 (ativos incorporados ao gel) - ao longo dos dias, sem controle de temperatura e umidade (a) e com controle de temperatura e umidade (b). SK $15=15 \%$ de sorbato de potássio não incorporado ao gel; PK $15=15 \%$ de permanganato de potássio não incorporado ao gel; PKG $15=15 \%$ de permanganato de potássio incorporado ao gel; SKG $15=15 \%$ de sorbato de potássio incorporado ao gel; SAA = espuma sem adição de ativos. 
Como pode ser observado na FIG. 32, a adição de agentes ativos fez com que as espumas de fécula de mandioca absorvessem, no geral, mais umidade ao longo dos dias. Quando não houve controle de temperatura e umidade relativa para o teste de absorção de umidade (FIG. 32(a)), apenas a espuma contendo 15\% de sorbato de potássio - adicionado pelo método 1 (não incorporação do ativo no gel - formulação SK 15) - apresentou menor teor de umidade $(7,45 \%)$ em relação à espuma sem ativos (formulação SAA - 8,01\%) no primeiro dia.

No teste em que a temperatura e umidade relativa foram controladas (FIG. 32(b)), todas as espumas contendo os ativos sorbato de potássio e permanganato de potássio (formulações SK 15, SKG 15, PK 15 e PKG 15) mostraram maior absorção de umidade logo no primeiro dia - ou seja, apresentaram teores de umidade maiores que o da espuma sem ativos (formulação SAA: 9,36\%). As espumas ativas produzidas por um mesmo método (incorporação ou não dos ativos no gel) apresentaram comportamentos de absorção de umidade muito semelhantes entre si. Porém, ao comparar as formulações de espumas produzidas por métodos diferentes verificaram-se diferenças nos comportamentos de absorção de umidade.

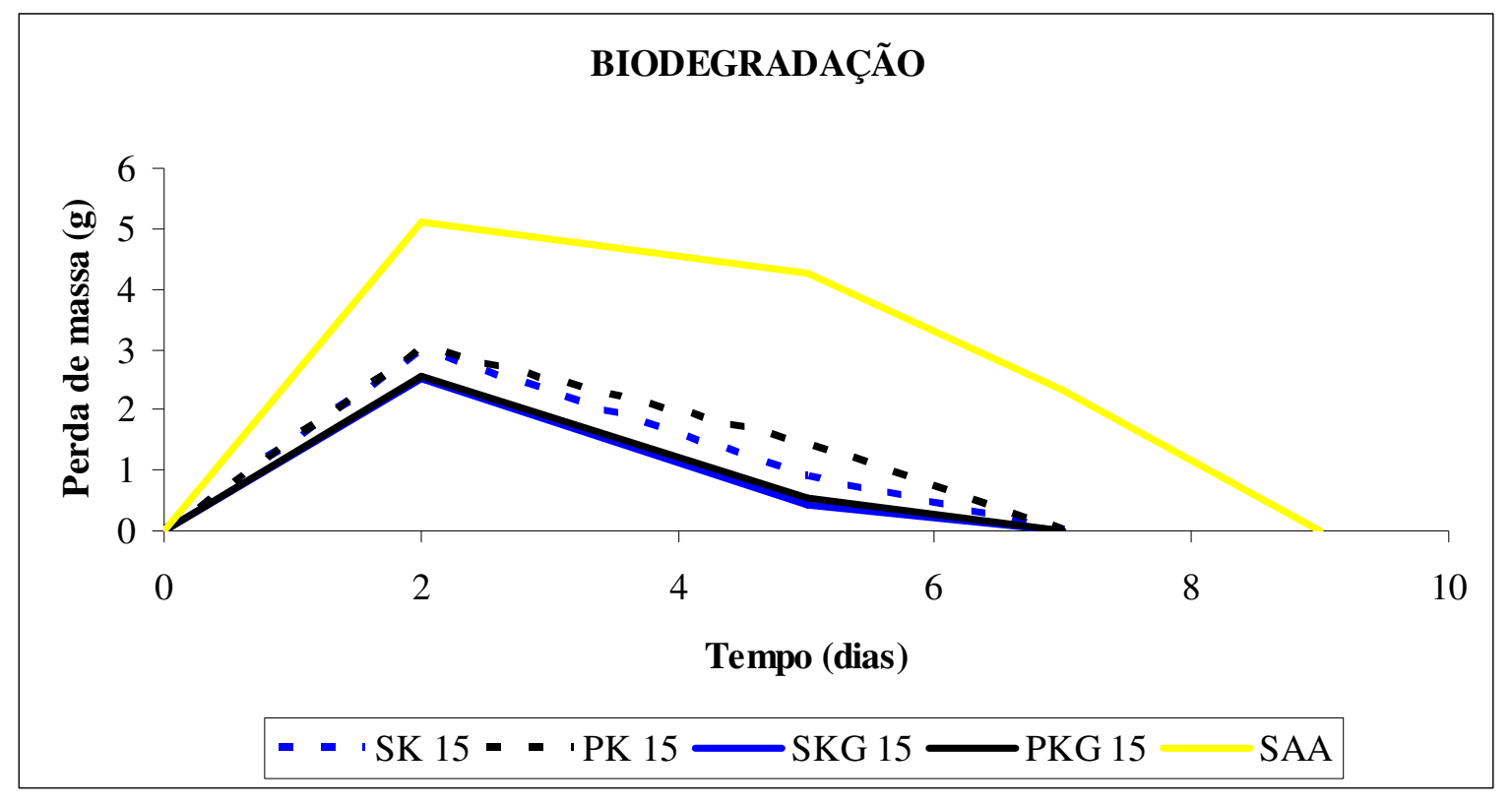

FIGURA 33 - Perda de massa das espumas de fécula de mandioca sem e com $15 \%$ de agentes ativos, adicionados à massa pelos métodos 1 (ativos não incorporados ao gel) e 2 (ativos incorporados ao gel). SK $15=15 \%$ de sorbato de potássio não incorporado ao gel; PK $15=15 \%$ de permanganato de potássio não incorporado ao gel; SKG $15=15 \%$ de 
sorbato de potássio incorporado ao gel; PKG $15=15 \%$ de permanganato de potássio incorporado ao gel; SAA = espuma sem adição de ativos.

Apesar das espumas de fécula de mandioca com agentes ativos mostrarem ser menos resistentes à tração e alongamento, e absorverem mais umidade (tanto por imersão em água quanto ao longo dos dias) em relação àquelas sem ativos, elas perderam massa mais rápido, como pode ser observado na FIG. 33. As espumas formuladas com $15 \%$ de sorbato de potássio e $15 \%$ de permanganato de potássio - adicionados por ambos os métodos (formulações SK 15, PK 15, SKG 15 e PKG 15) - perderam completamente suas massas em cerca de sete dias, enquanto aquela sem ativos (formulação SAA) levou nove dias para completa perda de massa.

\subsubsection{Adição de corantes naturais à massa}

Para se obter uma embalagem inteligente deve-se acrescentar à mistura de fécula, gel (fécula e água) e plastificante, um corante natural como indicador de $\mathrm{pH}$. O corante natural, além de colorir a espuma, monitora a vida de prateleira dos alimentos embalados. $\mathrm{O}$ corante natural (extratos de repolho roxo e beterraba), como indicador de $\mathrm{pH}$, fornece uma indicação visual (mudança de cor da embalagem) da qualidade do produto embalado. Muitos alimentos quando se deterioram sofrem alteração de $\mathrm{pH}$. Em contato com o alimento, a espuma de fécula com o corante natural muda de cor, indicando as condições do alimento embalado.

A mudança de $\mathrm{pH}$ da beterraba é justificada pelo processo de isomerização da betanina (agente cromóforo presente na beterraba). Em pH ácido, a betina converte-se em isobetanina e, em meio básico, a betanina é hidrolisada produzindo ciclodopa-5-Oglicosídio e ácido betâmico (Araújo, 1995). Já o repolho roxo possui no seu extrato as antocianinas que são responsáveis por uma variedade de cores atrativas e brilhantes de frutas, flores e folhas, que variam do vermelho alaranjado ao roxo, passando pelo vermelho vivo (Bobbio e Bobbio, 2003).

Às espumas de fécula de mandioca adicionamos extratos de beterraba e repolho roxo como indicadores de $\mathrm{pH}$. O aspecto visual das espumas com os extratos naturais, como indicadores de pH, está apresentado na FIG. 34. 
FIGURA 34 - Espumas de fécula de mandioca formuladas com extratos de beterraba (a) e repolho roxo (b).

Apesar da adição dos corantes naturais, nota-se que em ambas as espumas a mancha no centro permanece (decorrência do processo de termoprensagem), sendo mais visível na espuma com extrato de repolho roxo. As espumas produzidas possuem superfície lisa e cor uniforme.

$\mathrm{O}$ alimento acondicionado nas espumas inteligentes, ao sofrer qualquer alteração de $\mathrm{pH}$, provoca mudança na coloração da espuma, como pode ser observado nas FIG. 35 e 36 (para espumas de fécula de mandioca com repolho roxo e beterraba como indicadores de $\mathrm{pH}$, respectivamente). Essa mudança de coloração da espuma também foi percebida nos resultados dos testes sensoriais, no item 5.1.5.3.2. 


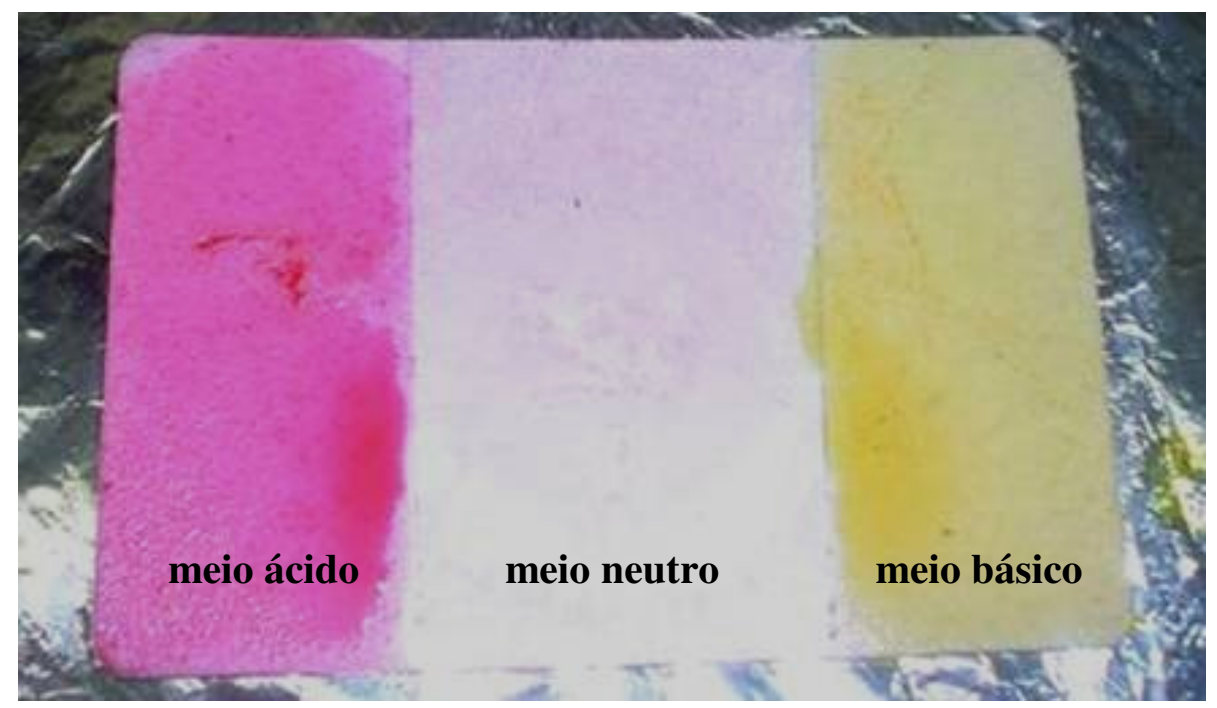

FIGURA 35 - Espuma de fécula de mandioca inteligente, contendo extrato de repolho roxo como indicador de $\mathrm{pH}$.

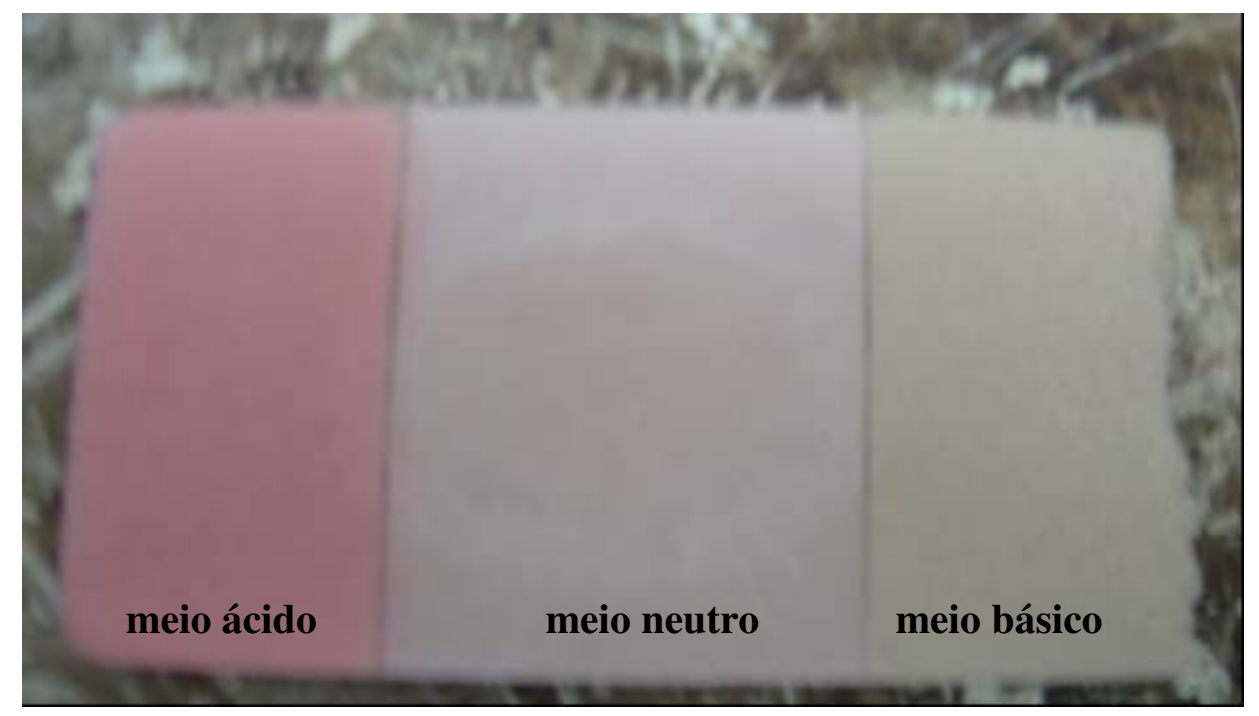

FIGURA 36 - Espuma de fécula de mandioca inteligente, contendo extrato de beterraba como indicador de $\mathrm{pH}$.

As espumas com os extratos naturais também foram submetidas a ensaios mecânicos (tração e alongamento) e de barreira (absorção de água) para verificar se a adição dos corantes alterou as propriedades das espumas. Para efeito de comparação, determinamos a força de tração e o alongamento na ruptura das espumas sem a adição de corantes (formulação SAA). Os resultados dos testes mecânicos estão apresentados na FIG. 37 e os resultados dos testes de barreira, na TAB. 8 . 


\section{RESISTÊNCIA À TRAÇÃo}

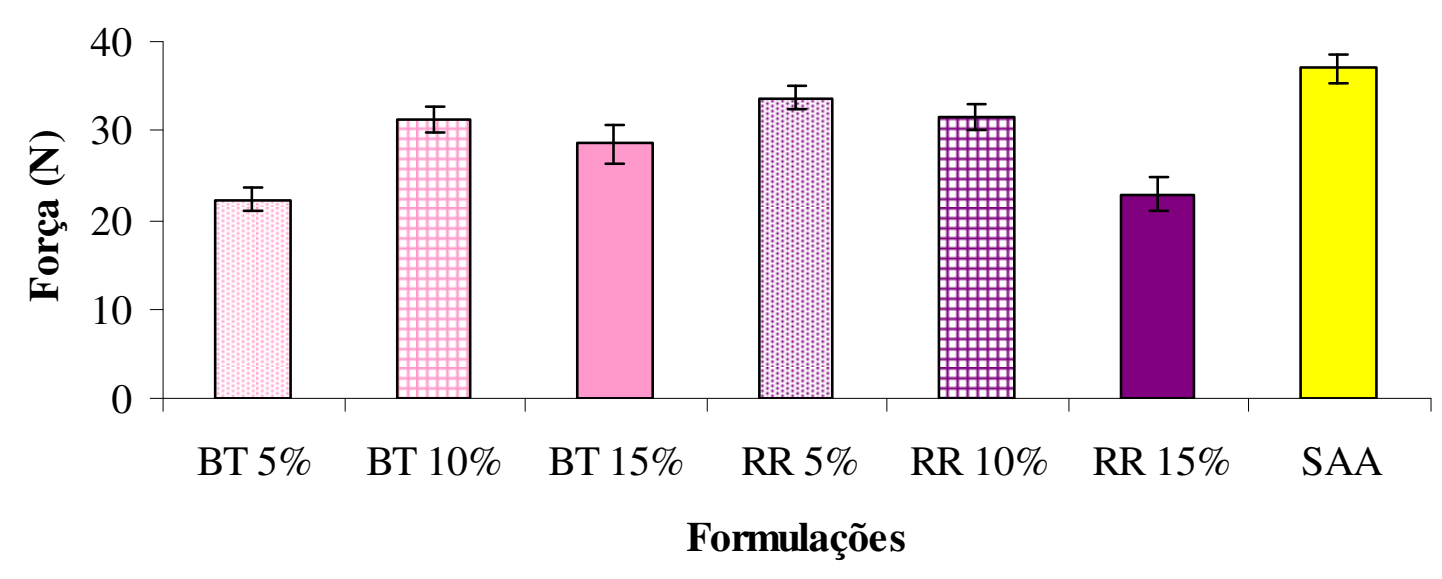

\section{ALONGAMENTO NA RUPTURA}

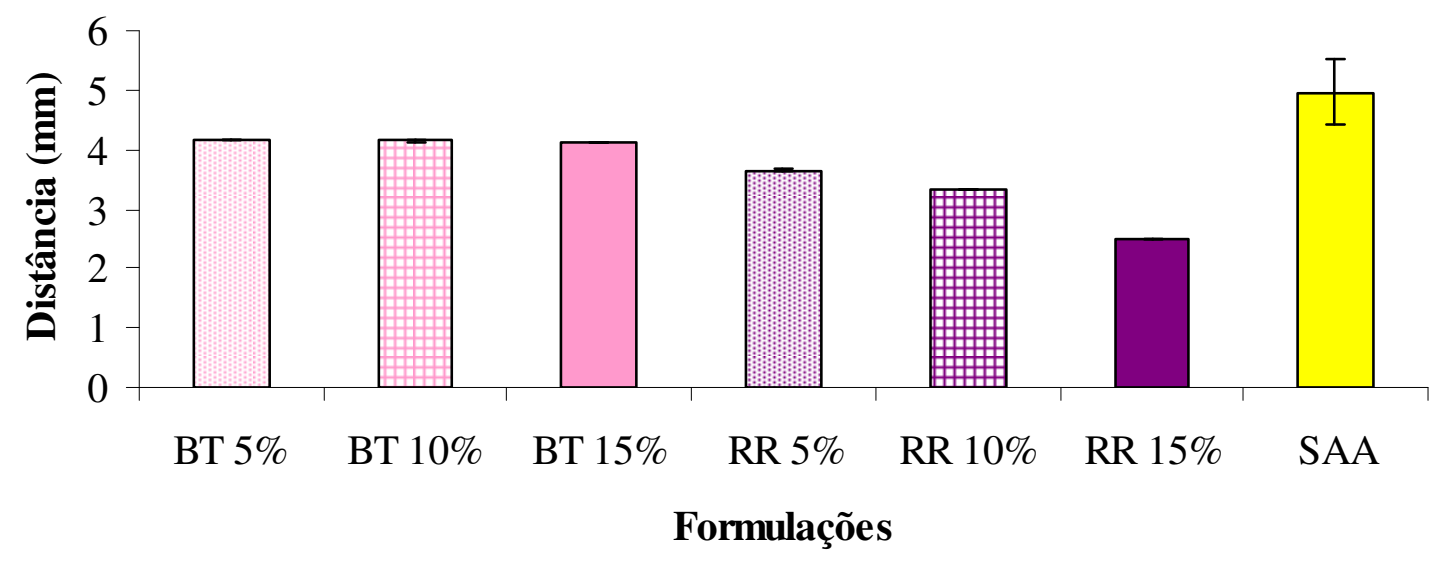

FIGURA 37 - Resistência à tração e alongamento na ruptura das espumas de fécula de mandioca com corantes naturais e sem corantes. BT 5\% =5\% de extrato de beterraba; BT $10 \%=10 \%$ de extrato de beterraba; BT $15 \%=15 \%$ de extrato de beterraba; RR 5\% $=5 \%$ de extrato de repolho roxo; RR 10\% $=10 \%$ de extrato de repolho roxo; RR 15\% $=15 \%$ de extrato de repolho roxo; SAA = espumas sem adição de corantes.

A adição dos corantes naturais às espumas de fécula de mandioca também não contribuiu para uma melhora de suas propriedades mecânicas. Apesar das espumas contendo os extratos naturais de beterraba e repolho roxo apresentarem melhor resistência à tração em relação aquelas contendo os ativos estudados (cloreto de cálcio, ácido ascórbico, sorbato de potássio e permanganato de potássio), ainda são menos resistentes 
que aquelas sem ativos e corantes (formulação SAA). Dentre os corantes adicionados, o repolho roxo, na concentração de 5\% (formulação RR 5\%), proporcionou maior resistência $(33,7 \pm 1,2 \mathrm{~N})$ à espuma, seguido das formuladas com $10 \%$ de repolho roxo (formulação RR 10\% - 31,6 \pm 1,5 N) e 10\% de beterraba (formulação BT 10\% - 31,3 \pm 1,5 N). A adição de 5\% de extrato de beterraba (formulação BT 5\%) à espuma tornou-a menos resistente $(22,3 \pm 1,3 \mathrm{~N})$. As espumas contendo $15 \%$ de extratos de repolho roxo (formulação RR 15\%) e beterraba (formulação BT 15\%) resistiram, respectivamente, às forças de 22,9 $\pm 1,8 \mathrm{~N}$ e 28,6 2,2 $\mathrm{N}$. De acordo com a análise estatística (ANOVA), as forças obtidas pelas espumas com 5\% de extrato de beterraba (BT 5\%) e 15\% de extrato de repolho roxo (RR 15\%) diferiram significativamente daquelas com $10 \%$ de extrato de repolho roxo (RR 10\%) e com 10 e $15 \%$ de extrato de beterraba (BT 10\% e BT 15\%). Estas, por sua vez, foram significativamente diferentes das espumas sem ativos (formulação SAA).

Em relação ao alongamento, as espumas em que o repolho roxo foi adicionado (formulações RR) mostraram ser menos flexíveis do que aquelas em que a beterraba foi adicionada (formulações BT) como corante, sendo que a utilização de 15\% de ambos os extratos naturais proporcionou menores valores de alongamento, enquanto que a utilização de $5 \%$ de extrato de beterraba resultou em valores maiores de alongamento na ruptura. Dentre os corantes estudados nas diferentes concentrações, o extrato de beterraba, na concentração de 5\% (formulação BT 5\%), proporcionou maior alongamento $(4,17 \mathrm{~mm}$ ) à espuma, seguido daquelas formuladas com $10 \%$ e $15 \%$ do mesmo extrato (formulações BT 10\% - 4,14 mm - e BT 15\% - 4,13 mm). A adição de 15\% de extrato de repolho roxo (formulação RR 15\%) à espuma tornou-a menos flexível $(2,48 \mathrm{~mm})$. As espumas com $10 \%$ e $5 \%$ deste último corante (formulações RR $10 \%$ e RR 5\%) resistiram, respectivamente, às distâncias de 3,31 mm e 3,65 mm. De acordo com a análise estatística (ANOVA), não houve diferença significativa para os valores de distância das espumas contendo $5 \%, 10 \%$ e $15 \%$ de extrato de beterraba, ao contrário das espumas com extrato de repolho roxo - que tiveram diferenças significativas entre as três concentrações estudadas. 
TABELA 8 - Resultados da absorção de água pelo isopor e pelas espumas de fécula de mandioca sem e com corantes naturais e em diferentes concentrações.

\begin{tabular}{lc}
\hline \multicolumn{1}{c}{ Formulações } & Teor de absorção de $\mathbf{H}_{2} \mathbf{O}^{*}(\boldsymbol{\%}) \pm$ Erro \\
\hline ISOPOR & $3,4 \pm 0,1$ \\
SAA & $23,3 \pm 0,9$ \\
BT 15\% & $26,2 \pm 1,2$ \\
BT 5\% & $27,8 \pm 1,4$ \\
BT 10\% & $33,0 \pm 1,1$ \\
RR 15\% & $34,9 \pm 1,1$ \\
RR 10\% & $42,8 \pm 1,5$ \\
RR 5\% & $45,7 \pm 1,3$ \\
*espumas imersas em 500 mL de água por 10 segundos à temperatura \\
ambiente. SAA = espuma sem adição de corantes; BT = extrato de \\
beterraba; RR = extrato de repolho roxo. \\
\hline
\end{tabular}

Pode-se verificar na TAB. 8 que a adição dos extratos naturais fez com que as espumas de fécula de mandioca absorvessem mais água. As formulações contendo extrato de beterraba absorveram menos água em relação àquelas contendo extrato de repolho roxo. As espumas produzidas por ambos corantes naturais tiveram praticamente o mesmo comportamento de absorção quanto às diferentes concentrações estudadas. Ou seja, generalizando, pode-se dizer que quanto maior a quantidade de extrato incorporado à embalagem, menor a absorção de água.

\subsubsection{Testes sensoriais das embalagens}

O presente trabalho avaliou, por meio de testes sensoriais, a aplicação de agentes ativos como: sorbato de potássio, permanganato de potássio e corantes naturais (extratos de beterraba e repolho roxo) em espumas de fécula de mandioca para o acondicionamento de banana e mamão (minimamente processados). Estas espumas foram produzidas anteriormente (itens 5.1.5.1 e 5.1.5.2), sendo os ativos adicionados na concentração de $15 \%$ e incorporados ao gel antes da homogeneização da massa no misturador de laboratório - representam as formulações SKG 15, PKG 15, BT 15 e RR 15. Tais formulações foram escolhidas para a execução dos testes de mercado, pois as espumas contendo permanganato de potássio (PKG 15) e sorbato de potássio (SKG 15) foram mais 
resistentes à tração do que aquelas com ácido ascórbico (AAG 15) e cloreto de cálcio (CCG 15) - resultados apresentados na FIG. 31. - e as espumas de beterraba e repolho roxo, na concentração de 15\% (BT 15 e RR 15), para verificar suas mudanças de cor.

A banana e o mamão foram escolhidos para a execução dos testes de mercado, porque são frutas climatéricas, originárias da América tropical, abundantes em nosso país e de grande preferência pela população. Em relação ao mamão, o Brasil conta com 31,57\% da área plantada mundial, o que torna o país o maior produtor mundial e o maior em produtividade (48,57ton/ha) (Souza, 2002).

As frutas foram acondicionadas em potes de polipropileno $(5,5 \mathrm{~cm}$ de diâmetro $\mathrm{x}$ 4,5 cm de altura), selados com espumas de fécula de mandioca (com e sem agentes ativos), poliestireno expandido (isopor) e potes de polipropileno (com tampa), num total de 10 potes para cada tratamento. Os potes foram armazenados em geladeira a $10 \pm 1^{\circ} \mathrm{C}$ por 7 dias (para o teste sensorial com banana) e 20 dias (para o teste sensorial com mamão). A cada 2 dias foram retirados dois potes de cada tratamento. A qualidade dos frutos foi determinada por análises físico-químicas (redução da massa fresca - medida pela diferença entre o peso inicial e final da fruta - e $\mathrm{pH}$ - medido em potenciômetro digital) e sensoriais (aparência e textura).

\subsection{Com banana}

Os resultados de redução da massa fresca das fatias de banana estão apresentados na FIG. 38. Como pode ser observado, as bananas armazenadas em copinhos de polipropileno, selados com espumas ativas de fécula de mandioca e poliestireno expandido (isopor), armazenados em geladeira, vão perdendo massa fresca, ou melhor, água no decorrer dos dias. 


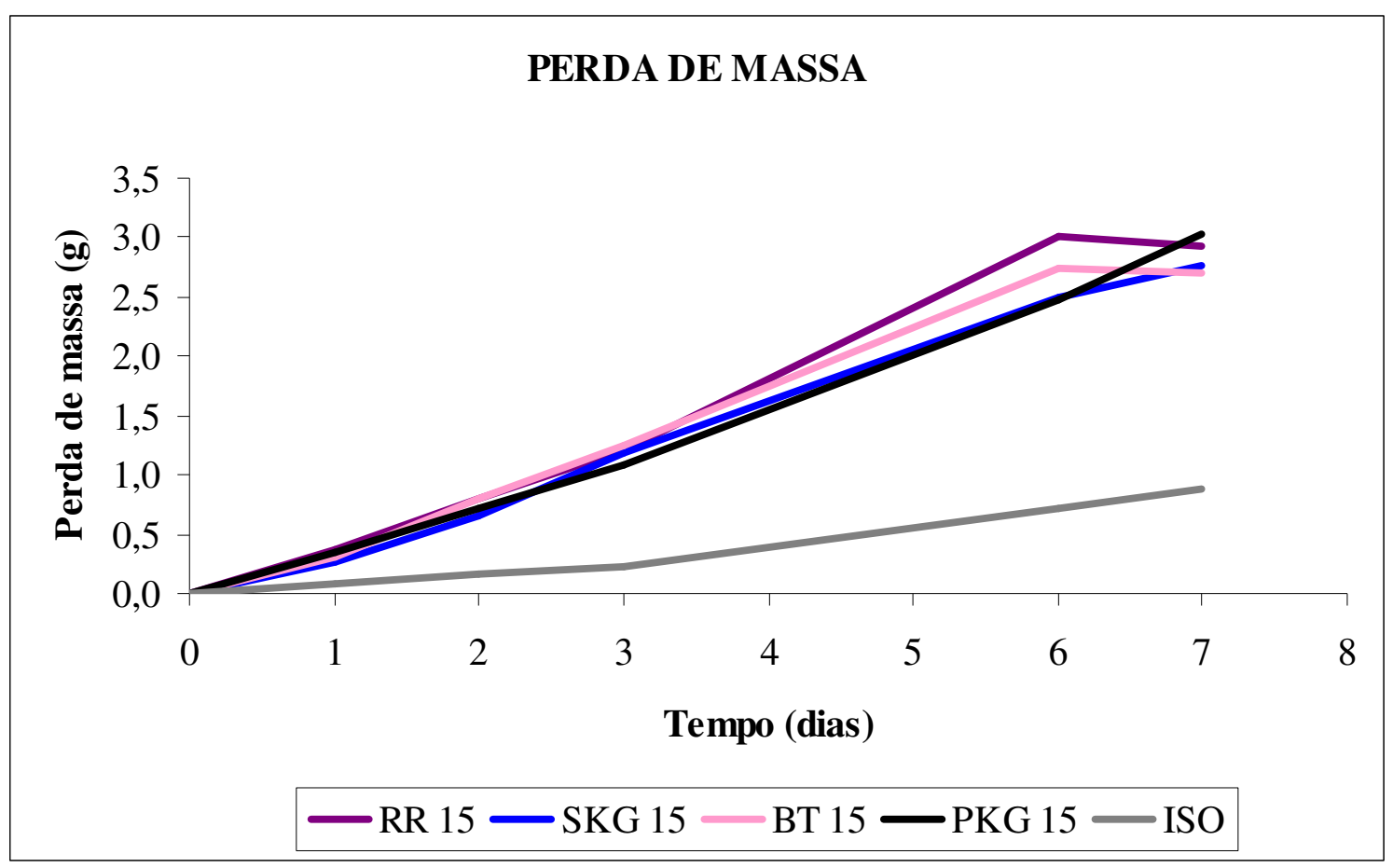

FIGURA 38 - Redução de massa fresca dos pedaços de banana minimamente processados, armazenados a $10^{\circ} \mathrm{C}$. RR $15=15 \%$ de extrato de repolho roxo; SKG $15=$ $15 \%$ de sorbato de potássio; BT $15=15 \%$ de extrato de beterraba; PKG $15=15 \%$ de permanganato de potássio; ISO = isopor.

Nota-se na FIG. 38, que as fatias de banana armazenadas nos copinhos selados por isopor foram as que menos sofreram variações em suas massas, ou seja, praticamente não perderam água. Sua diferença de massa após 7 dias estocadas em geladeira foi de apenas 0,88g. Já aquelas armazenadas nos copinhos selados por espumas ativas de fécula de mandioca apresentaram praticamente o mesmo comportamento, sendo que a espuma contendo $15 \%$ de extrato de beterraba (formulação BT 15) foi a que menos interferiu na variação de peso das fatias de banana - sua diferença de massa após 7 dias estocada em geladeira foi de 2,69g. Portanto, o extrato de beterraba, como aditivo ativo, se mostrou eficiente para evitar a perda de peso das frutas embaladas. A espuma que obteve maior variação no peso das fatias de banana foi aquela com permanganato de potássio (formulação PKG 15), correspondendo a uma diferença de massa das bananas igual a 3,04g após 7 dias estocadas em geladeira.

Apesar de ter a maior perda de massa fresca, o permanganato de potássio aplicado nas embalagens de fécula de mandioca é o mais recomendado para o uso no processamento de bananas minimamente processadas, pois aumentou a vida útil de comercialização da 
banana e não apresentou diferença significativa dos parâmetros sensoriais quando comparados com bananas recém processadas. Resultados análogos foram obtidos por Brackmann et al. (2006). Os autores estudaram a eficiência da absorção de etileno e da utilização da atmosfera modificada e controlada na conservação da qualidade da banana prata. Segundo os autores, a absorção de etileno pelo permanganato de potássio $\left(\mathrm{KMnO}_{4}\right)$ melhorou a qualidade da banana prata, tanto no armazenamento a $25^{\circ} \mathrm{C}$ como a $12^{\circ} \mathrm{C}$. Segundo Jiang et al. (1999), o armazenamento das bananas à temperatura ambiente pode ser semelhante ao do armazenamento refrigerado, desde que os frutos estejam embalados em filmes de polietileno com $\mathrm{KMnO}_{4}$ para absorver etileno.

\section{(a) Influência da embalagem utilizada}

A vida útil de comercialização das fatias de banana armazenadas em potes de polipropileno selados com espumas de fécula de mandioca (sem agentes ativos) e isopor foi feita por percepção visual de presença ou não de fungos ou escurecimento da fruta embalada. Quando uma destas situações era observada, a fruta era automaticamente descartada.

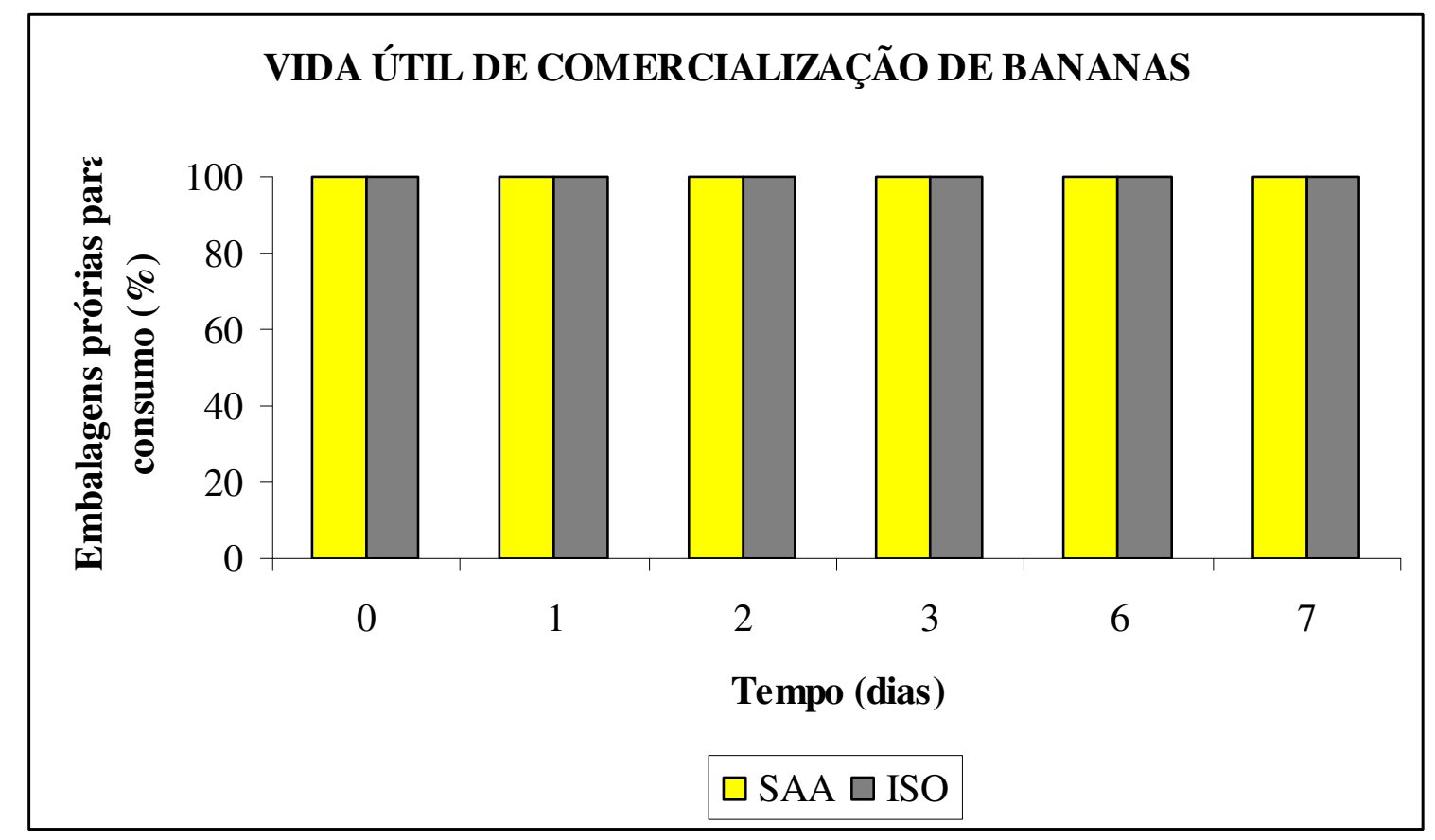

FIGURA 39 - Vida útil de comercialização de bananas minimamente processadas e armazenadas a $10^{\circ} \mathrm{C}$ em espumas de fécula de mandioca sem ativos (formulação SAA) e em isopor (ISO). 
Observa-se na FIG. 39, que as bananas minimamente processadas e refrigeradas a $10^{\circ} \mathrm{C}$ tiveram em todos os potes, selados com espumas de fécula e poliestireno expandido (isopor), $100 \%$ de potes próprios para consumo até o $7^{\circ}$ dia de estocagem. Tanto as espumas de fécula de mandioca (sem ativos) quanto as embalagens de isopor são próprias para o consumo de bananas no prazo de uma semana.

\section{(b) Influência do pH nas embalagens}

A qualidade das fatias de banana, embaladas em potes de polipropileno e selados com espumas ativas de fécula de mandioca e isopor, também foi determinada por medida do pH. Os resultados estão apresentados na TAB. 9.

TABELA 9 - pH das fatias de banana (armazenadas em geladeira), seladas com espumas ativas de fécula de mandioca e isopor, ao longo de 7 dias.

\begin{tabular}{|c|c|c|c|c|c|}
\hline $\begin{array}{l}\text { Tempo } \\
\text { (dias) }\end{array}$ & SKG 15* & PKG 15* & BT 15* & RR 15* & ISO $* *$ \\
\hline $\mathbf{0}$ & 4,71 & 4,71 & 4,71 & 4,71 & 4,71 \\
\hline 1 & 4,71 & 4,67 & 4,64 & 4,72 & 4,65 \\
\hline 2 & 4,35 & 3,98 & 4,06 & 4,14 & 4,19 \\
\hline 3 & 4,07 & 4,00 & 4,10 & 4,05 & 3,99 \\
\hline 6 & 4,83 & 4,89 & 4,97 & 4,81 & 4,68 \\
\hline 7 & 4,60 & 4,60 & 4,61 & 4,74 & 4,46 \\
\hline \multicolumn{6}{|c|}{$\begin{array}{l}\text { *espumas ativas de fécula de mandioca: } \mathrm{SKG} 15=15 \% \text { de sorbato de potássio; PKG } 15 \\
=15 \% \text { de permanganato de potássio; BT } 15=15 \% \text { de extrato de beterraba; RR } 15=15 \% \\
\text { de extrato de repolho roxo. } \\
* * \text { ISO }=\text { embalagem de isopor. }\end{array}$} \\
\hline
\end{tabular}

Como pode ser observado na TAB. 9, os valores de $\mathrm{pH}$ diminuíram na maioria dos experimentos. Isso se deve à produção de ácidos orgânicos de reações bioquímicas (ácidos málico e cítrico) durante o armazenamento. Lima et al. (2005) e Silva et al. (2003) também observaram diminuição do $\mathrm{pH}$ no armazenamento de mamão e abacaxi, respectivamente. Dentre as embalagens estudadas no teste sensorial com banana, o isopor foi aquela responsável por maior redução de $\mathrm{pH}$ da fruta (4,46 no sétimo dia de estocagem), sendo as espumas de fécula de mandioca embalagens que melhor conservaram as fatias de banana. Após uma semana de armazenamento refrigerado, verifica-se que os pHs das bananas seladas com as espumas foram muito semelhantes - 
em torno de 4,60 para as espumas contendo os ativos sorbato de potássio (formulação SKG 15), permanganato de potássio (formulação PKG 15) e extrato de beterraba (formulação BT 15) e pH de 4,74 para a espuma com extrato de repolho roxo (formulação RR 15).

\subsection{Com mamão}

O teste sensorial com mamão, assim como o de banana, estudou o comportamento de perda de massa fresca dos pedaços de mamão durante os dias em que ficaram estocados na geladeira a $10^{\circ} \mathrm{C}$, armazenados em potes de polipropileno e selados com espuma de fécula de mandioca contendo os agentes ativos já citados anteriormente no item 5.1.5.3. Para efeito de comparação, este teste foi aplicado em embalagens convencionais de poliestireno expandido (isopor) e polipropileno. Os resultados de redução da massa fresca dos pedaços de mamão estão apresentados na FIG. 40.

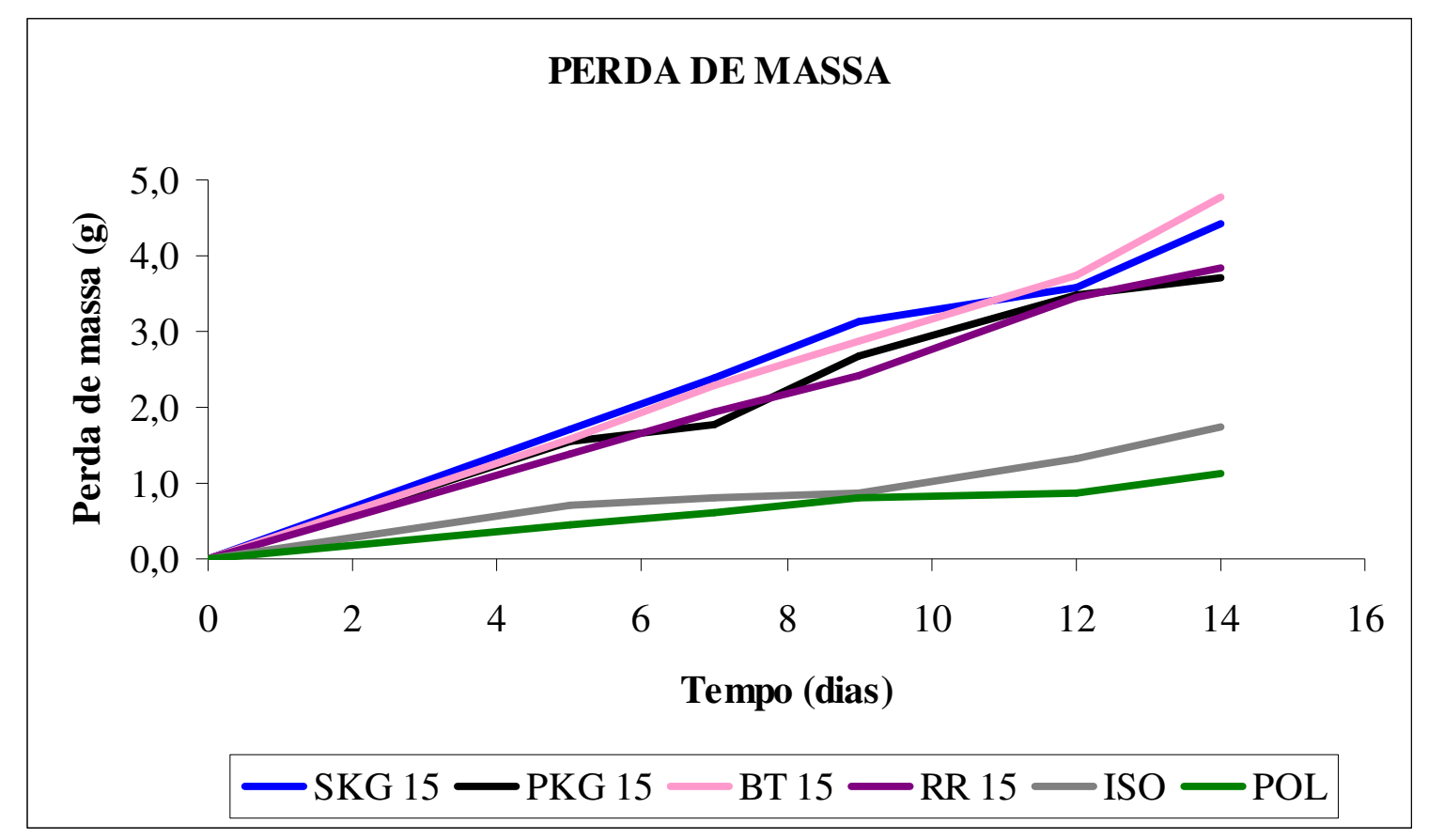

FIGURA 40 - Redução de massa fresca dos pedaços de mamão minimamente processados, armazenados a $10^{\circ} \mathrm{C}$. SKG $15=15 \%$ de sorbato de potássio; PKG $15=15 \%$ de permanganato de potássio; BT $15=15 \%$ de extrato de beterraba; RR $15=15 \%$ de extrato de repolho roxo; $\mathrm{ISO}=$ isopor; $\mathrm{POL}=$ embalagem de polipropileno. 
Como pode ser observado na FIG. 40, os mamões dentro dos copinhos selados por diferentes formulações de espumas de fécula de mandioca, de isopor e de polipropileno, armazenados em geladeira, vão perdendo massa, ou melhor, água no decorrer dos dias.

Nota-se que os pedaços de mamão armazenados nos copinhos tampados por polipropileno foram os que menos sofreram variações em suas massas, seguidos daqueles selados com isopor, ou seja, tanto em polipropileno como em isopor os pedaços de mamão praticamente não perderam água. A diferença de massa do mamão selado com polipropileno após 14 dias estocado em geladeira foi de $1,11 \mathrm{~g}$, enquanto que com isopor foi de 1,73g. Já aqueles armazenados nos copinhos tampados por diferentes formulações de espumas ativas de fécula de mandioca apresentaram praticamente o mesmo comportamento, sendo que a espuma com permanganato de potássio (formulação PKG 15) foi a que menos interferiu na variação de peso dos pedaços de mamão - sua diferença de massa após 14 dias estocado em geladeira foi de 3,71g. E a espuma que causou maior variação no peso dos pedaços de mamão foi aquela com extrato de beterraba (formulação BT 15), correspondendo a uma diferença de massa dos mamões igual a 4,76g após 14 dias estocados em geladeira.

\section{(a) Influência da embalagem utilizada}

A vida útil de comercialização dos pedaços de mamão armazenados em potes de polipropileno selados com espuma de fécula de mandioca (com e sem agentes ativos), isopor e em embalagem de polietileno foi feita por percepção visual de presença ou não de fungos ou escurecimento da fruta embalada. Quando uma destas situações era observada, a fruta era automaticamente descartada. Os resultados da vida útil de comercialização dos mamões selados com espuma de fécula de mandioca sem ativos (formulação SAA), isopor e polietileno estão apresentados na FIG. 41. 


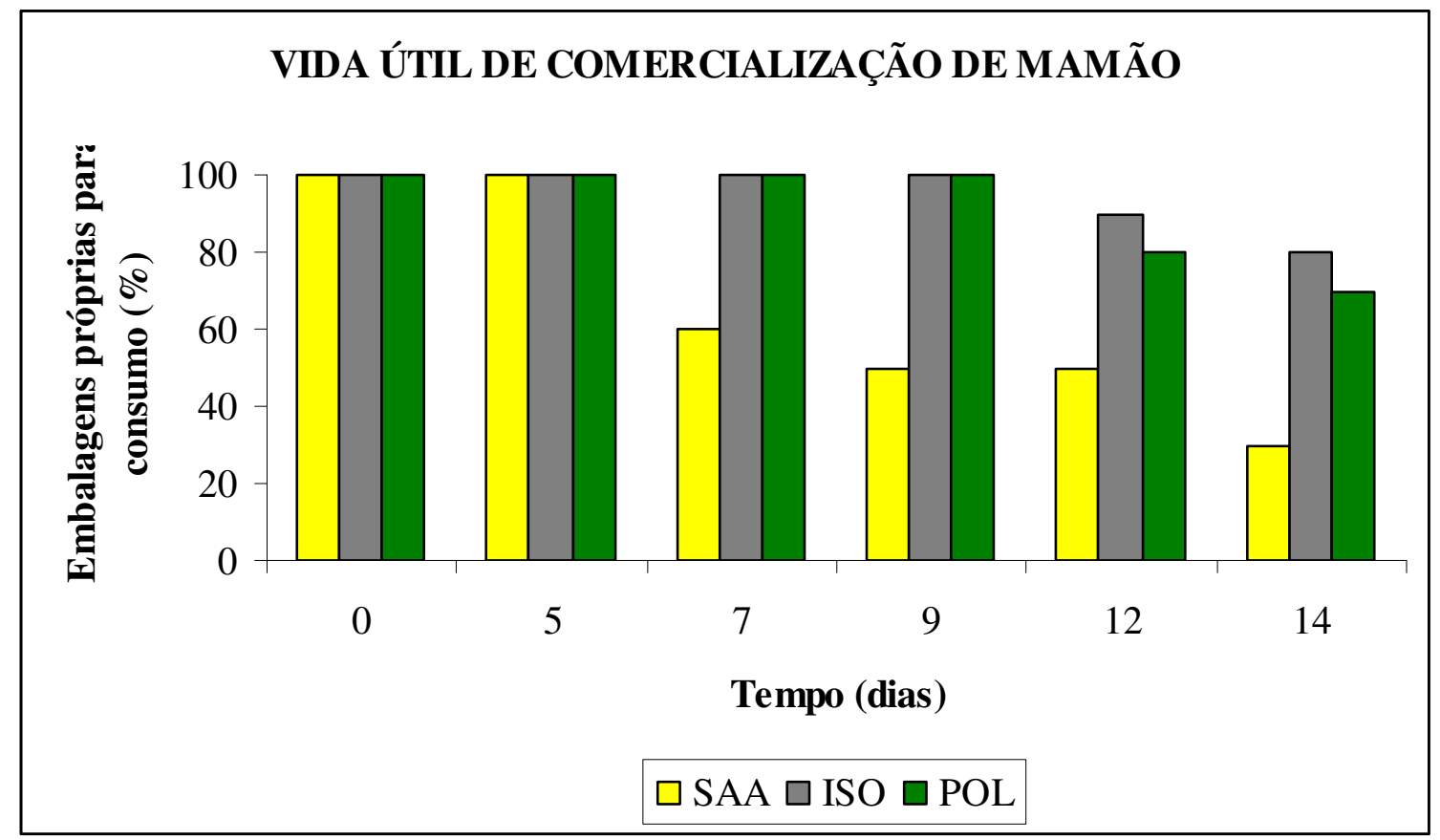

FIGURA 41 - Vida útil de comercialização de mamões minimamente processados, armazenados em potes de polipropileno e selados com espumas de fécula de mandioca sem ativos (formulação SAA) e com embalagens convencionais de isopor (ISO) e polietileno (POL).

As embalagens feitas a partir de fécula de mandioca, sem agentes ativos (formulação SAA), mostraram eficiência total (100\%) na preservação do mamão até o quinto dia armazenado em geladeira. A partir de então começaram a aparecer bolores (observados visualmente), tornando tais embalagens impróprias para o consumo após 5 dias estocadas sob refrigeração $\left(10^{\circ} \mathrm{C}\right)$ - apenas $60 \%$ delas estavam em condições próprias para o consumo do mamão no sétimo dia. Já as embalagens convencionais de isopor (ISO) e polietileno (POL) mostraram eficiência total (100\%) até o nono dia em que ficaram armazenadas na geladeira. As características deteriorantes no mamão, nessas duas últimas embalagens, começaram a aparecer a partir do décimo segundo dia sob refrigeração, no qual $90 \%$ das embalagens de isopor e $80 \%$ das embalagens de polietileno estavam em condições próprias para o consumo.

Logo, as espumas de fécula de mandioca sem agentes ativos neste teste sensorial preservaram menos as características normais da fruta em relação às embalagens convencionais. As embalagens de fécula de mandioca, sem agentes ativos, são eficazes no armazenamento de mamão por 5 dias. 
A vida útil de comercialização dos pedaços de mamão armazenados em potes de polipropileno selados com espumas de fécula de mandioca contendo os diferentes agentes ativos (sorbato de potássio, permanganato de potássio e extratos naturais de beterraba e repolho roxo) também foi estudada, para melhor análise da influência dos ativos nas espumas sobre a fruta, durante o armazenamento a $10^{\circ} \mathrm{C}$. Para efeito de comparação, determinamos a vida útil de comercialização dos pedaços de mamão armazenados em potes de polietileno com tampa e outros selados com isopor. Os resultados estão apresentados na FIG. 42.

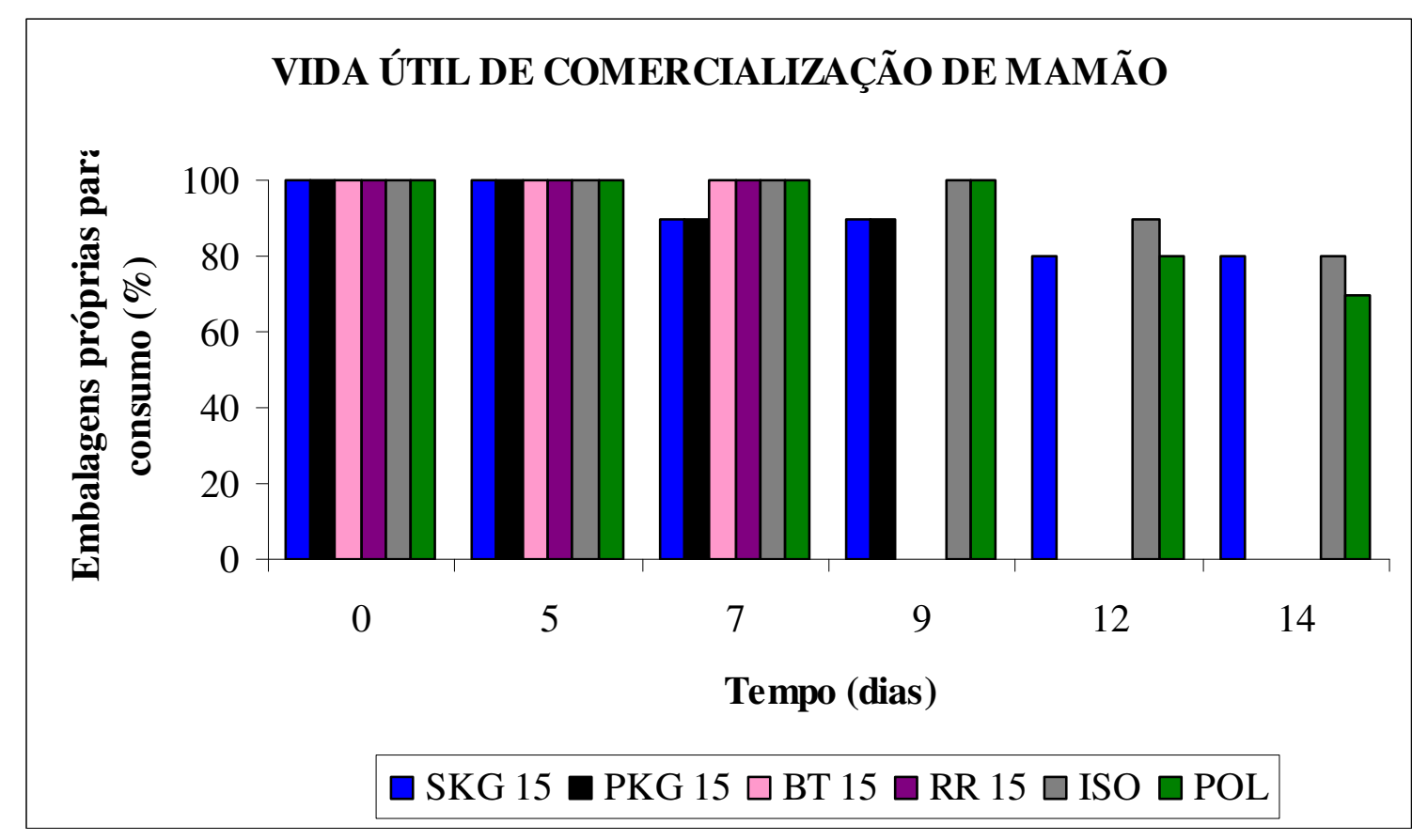

FIGURA 42 - Vida útil de comercialização de mamões minimamente processados, armazenados a $10^{\circ} \mathrm{C}$ em potes de polipropileno, e selados com espumas ativas de fécula de mandioca e embalagens convencionais de isopor e polietileno. SKG $15=15 \%$ de sorbato de potássio; PKG $15=15 \%$ de permanganato de potássio; BT $15=15 \%$ de extrato de beterraba; RR $15=15 \%$ de extrato de repolho roxo; $\mathrm{ISO}=$ isopor; $\mathrm{POL}=$ polietileno.

Pode-se notar na FIG. 42, que dentre as espumas ativas de fécula de mandioca, aquelas com permanganato de potássio (absorve etileno - gás associado ao escurecimento da fruta) e sorbato de potássio (evita a proliferação de fungos) - formulações PKG 15 e SKG 15 - foram as mais efetivas para aumentar o tempo de prateleira dos mamões, pois apresentavam $90 \%$ de embalagens sem incidência de fungos visuais, após 9 dias, ao passo que as espumas de fécula de mandioca com extratos de beterraba (formulação BT 15) e 
repolho roxo (formulação RR 15) já apresentavam um percentual de $0 \%$ de embalagens próprias para consumo. Lima et al. (2005) avaliaram a aplicação de agentes antiescurecimento (ácido benzóico), antimicrobiano (sorbato de potássio) e inibidor da perda de peso (cloreto de cálcio), além da aplicação de filmes plásticos (polietileno e PVC), em pedaços de mamão. Os agentes ativos foram aplicados às frutas por imersão das mesmas em solução contendo o ativo. Os autores observaram que os melhores resultados sensoriais foram obtidos em mamão embalado com filme de PVC e aplicação de sorbato de potássio $(0,75 \%, \mathrm{p} / \mathrm{v})$ na fruta e que o cloreto de cálcio e o ácido benzóico pouco contribuíram para o aumento da vida útil de comercialização do produto.

A figura abaixo (FIG. 43) mostra a ausência de bolor no mamão selado com espumas de fécula de mandioca contendo permanganato de potássio e sorbato de potássio, e a formação de bolores em mamão selados com isopor e polietileno, após 14 dias de refrigeração.

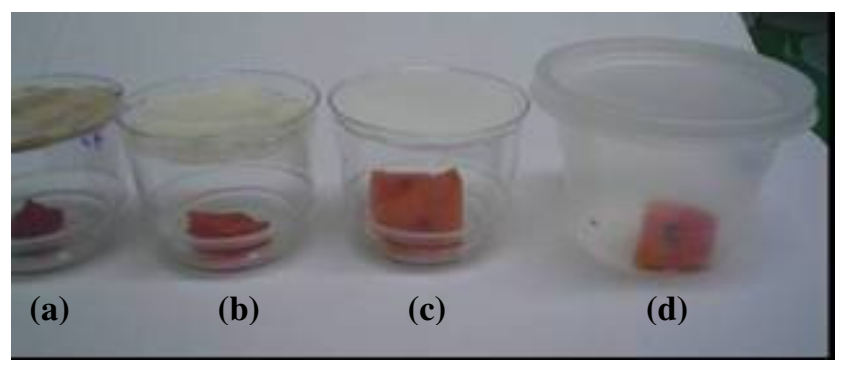

FIGURA 43 - Ausência de bolor nos pedaços de mamão cobertos pelas espumas de fécula de mandioca contendo (a) permanganato de potássio e (b) sorbato de potássio; e formação de bolor em mamão coberto por isopor (c) e em embalagem de polietileno (d).

Dentre as espumas de fécula de mandioca, os pedaços de mamão cobertos pela espuma contendo o agente ativo permanganato de potássio (FIG. 43(a) - formulação PKG 15) foram os que apresentaram $\mathrm{pH}$ mais alto (5,54 - vide TAB. 10), mostrando que, após 14 dias de refrigeração, foram os que menos sofreram reações de deterioração. Os pedaços de mamão selados com espuma contendo o ativo sorbato de potássio (formulação SKG 15), apesar de apresentaram pH mais baixo (5,04 - vide TAB. 10), mostraram que após 14 dias de refrigeração não sofreram deterioração. Já os pedaços de mamão selados com isopor (ISO) e os armazenados em embalagem de polietileno (POL) foram aqueles que mais se deterioraram - com formação de bolores - e em menor tempo comparado ao surgimento de bolor nos pedaços de mamão selados com as espumas de fécula de mandioca. A FIG. 44 mostra o resultado da espuma com extrato de repolho roxo no teste 
de mercado com mamão após 14 dias. Pode-se verificar a função do extrato, como indicador de $\mathrm{pH}$, indicando visualmente (mudança de cor da espuma para a cor rosa claro) a qualidade do mamão armazenado em geladeira.

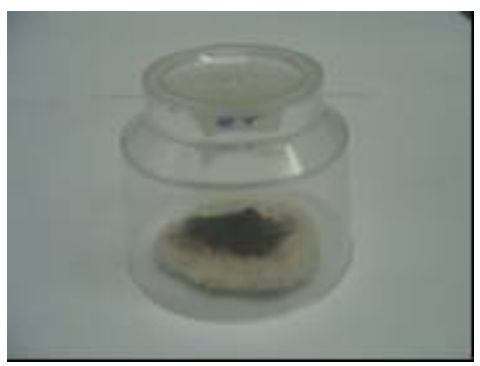

(a)

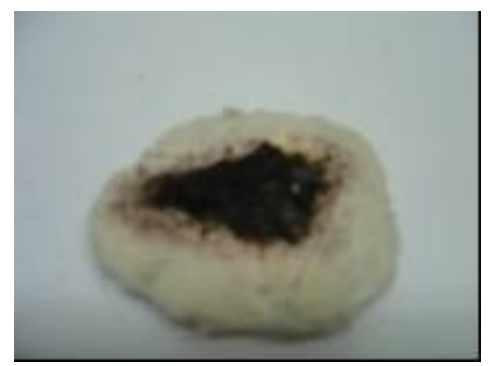

(b)

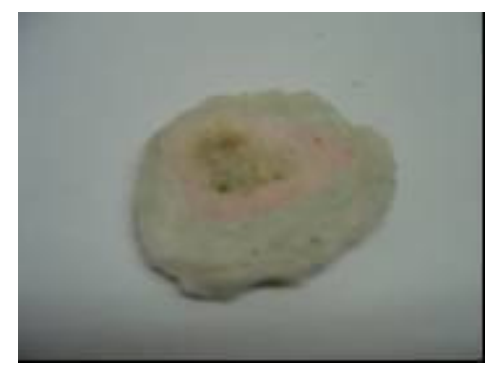

(c)

FIGURA 44 - Mudança de cor da espuma contendo extrato natural de repolho roxo (formulação RR 15) após 14 dias de refrigeração do pedaço de mamão em contato com a espuma. $(\mathbf{a})=$ mamão em contato com a espuma ativa coberto por bolor; $(\mathbf{b})=$ mudança de cor da espuma (cor rosa claro ao redor do pedaço de mamão coberto por bolor); (c) = espuma virada de ponta-cabeça para melhor visualização de sua mudança de cor.

\section{(b) Influência do pH nas embalagens}

A qualidade dos pedaços de mamão, embalados em potes de polipropileno e selados com espumas ativas de fécula de mandioca, isopor e polietileno, também foi determinada por medida do $\mathrm{pH}$. Os resultados estão apresentados na TAB. 10.

TABELA 10 - pH dos pedaços de mamão (armazenados em geladeira), selados com espumas ativas de fécula de mandioca, isopor e polietileno, ao longo de 14 dias.

\begin{tabular}{|c|c|c|c|c|c|c|}
\hline $\begin{array}{c}\text { Tempo } \\
\text { (dias) }\end{array}$ & SKG 15* & PKG 15* & BT 15* & RR 15* & ISO** & POL*** \\
\hline $\mathbf{0}$ & 6,00 & 6,00 & 6,00 & 6,00 & 6,00 & 6,00 \\
\hline $\mathbf{5}$ & 5,58 & 5,48 & 5,54 & 5,56 & 5,53 & 5,62 \\
\hline $\mathbf{7}$ & 5,59 & 5,44 & 5,29 & 5,68 & 5,31 & 5,42 \\
\hline $\mathbf{9}$ & 5,12 & 5,04 & 5,21 & 5,81 & 5,37 & 5,30 \\
\hline $\mathbf{1 2}$ & 5,51 & 5,40 & 5,02 & 4,96 & 5,46 & 4,98 \\
\hline $\mathbf{1 4}$ & 5,04 & 5,54 & 5,19 & 5,51 & 4,35 & 4,50 \\
\hline
\end{tabular}

*espumas ativas de fécula de mandioca: SKG $15=15 \%$ de sorbato de potássio; PKG 15 $=15 \%$ de permanganato de potássio; BT $15=15 \%$ de extrato de beterraba; RR $15=15 \%$ de extrato de repolho roxo.

$* *$ ISO $=$ embalagem de isopor.

$* * * \mathrm{POL}=$ embalagem de polietileno. 
A TAB. 10 mostra que o pH dos mamões dentro dos copinhos selados por diferentes formulações de espumas ativas de fécula de mandioca, por isopor e polietileno, armazenados em geladeira, também diminuiu ao longo dos dias. Como já mencionado anteriormente, no teste sensorial com bananas, isso se deve à produção de ácidos orgânicos de reações bioquímicas (ácidos málico e cítrico) durante o armazenamento. Lima et al. (2005) e Silva et al. (2003) também observaram diminuição do pH no armazenamento de mamão e abacaxi, respectivamente. Em relação ao pH dos pedaços de mamão, as embalagens convencionais de isopor e polietileno foram as mais impróprias para a conservação dos mesmos - apresentaram, após 14 dias de refrigeração, pH inferiores aos dos pedaços acondicionados em espumas ativas de fécula de mandioca.

\subsubsection{Extrusão versus Termoprensagem para obtenção das embalagens ativas de}

\section{fécula de mandioca tipo espuma}

Os objetivos neste item do trabalho foram verificar a influência:

(a) das quantidades de massa pura e extrusada, com e sem agentes ativos, necessárias para formar uma espuma - por termoprensagem - no peso final das mesmas. Diz-se "massa pura" aquela obtida pelo misturador de laboratório e "massa extrusada" aquela obtida após a extrusão da massa pura.

(b) dos processos de produção nas propriedades mecânicas das embalagens ativas de fécula de mandioca.

Tais embalagens foram obtidas pelos processos de termoprensagem e de extrusão (seguida de termoprensagem) de uma mistura de 57\% de fécula de mandioca (do estado do Paraná - marca Lorenz), gel (fécula suspensa em água), $2 \%$ de plastificante polietilenoglicol (PEG 300) em peso dos sólidos e agentes ativos (permanganato de potássio, sorbato de potássio e extratos naturais de beterraba e repolho roxo - incorporados individualmente ao gel na concentração de 15\%). Apesar das espumas sem ativos (formulação SAA) e das com os ativos mencionados (formulações PKG 15, SKG 15, RR 15 e BT 15) já terem sido produzidas por termoprensagem (de massa pura), resolveu-se produzi-las novamente neste item do projeto para melhor compará-las às espumas feitas pelo processo de extrusão seguida de termoprensagem - ou seja, para comparar os dois processos de produção de um mesmo "lote".

A TAB. 11 apresenta os pesos das espumas ativas (em forma de placas retangulares) produzidas por termoprensagem de quantidades de massas pura e extrusada. 
Para efeito de comparação, os pesos das espumas sem ativos (formulação SAA) também estão apresentados na tabela a seguir.

TABELA 11 - Pesos das espumas sem e com ativos (permanganato de potássio, sorbato de potássio e extratos naturais de beterraba e repolho roxo) após termoprensagem de quantidades de massa pura e massa extrusada.

\begin{tabular}{|l|c|c|c|}
\hline \multicolumn{1}{|c|}{ Formulações* } & $\begin{array}{c}\text { Quantidade Média } \\
\text { de massa (pura e } \\
\text { extrusada) antes da } \\
\text { termoprensagem } \\
(\mathbf{g}) \pm \text { Erro }\end{array}$ & $\begin{array}{c}\text { Peso Médio da } \\
\text { espuma após } \\
\text { termoprensagem } \\
\text { de massa pura } \\
(\mathbf{g}) \pm \text { Erro }\end{array}$ & $\begin{array}{c}\text { Peso Médio da } \\
\text { espuma após } \\
\text { termoprensagem } \\
\text { de massa extrusada } \\
(\mathbf{g}) \pm \text { Erro }\end{array}$ \\
\hline PKG 15 & $8,03 \pm 0,42$ & $4,65 \pm 0,32$ & $5,51 \pm 0,35$ \\
\hline SKG 15 & $8,08 \pm 0,38$ & $4,60 \pm 0,21$ & $5,30 \pm 0,26$ \\
\hline BT 15 & $8,13 \pm 0,42$ & $4,84 \pm 0,14$ & $5,16 \pm 0,26$ \\
\hline RR 15 & $8,13 \pm 0,42$ & $4,54 \pm 0,26$ & $5,17 \pm 0,25$ \\
\hline SAA & $8,13 \pm 0,42$ & $4,58 \pm 0,24$ & $5,33 \pm 0,25$ \\
\hline $\begin{array}{l}\text { *os ativos foram incorporados ao gel antes da homogeneização da massa no misturador de } \\
\text { laboratório. PKG 15 }=15 \% \text { de permanganato de potássio; SKG 15 = 15\% de sorbato de } \\
\text { potássio; BT 15 }=15 \% \text { de extrato natural de beterraba; RR 15 } 15 \% \text { de extrato natural de } \\
\text { repolho roxo; SAA }=\text { espuma sem ativos. }\end{array}$ \\
\hline
\end{tabular}

Após a termoprensagem das massas - tanto da pura quanto da extrusada - verificase uma redução dos pesos das espumas praticamente à metade das quantidades de massas antes da termoprensagem. Este fenômeno já era esperado devido à evaporação da água contida na mistura (massa) durante o processo de termoprensagem para formação das espumas. Nota-se também que as espumas obtidas por termoprensagem de massa extrusada são um pouco mais pesadas em relação àquelas obtidas por termoprensagem de massa pura. Após a extrusão, o material torna-se mais rígido devido à compactação de sua estrutura molecular e, consequentemente, mais pesado. Durante o processo de termoprensagem, a massa extrusada expande menos que a massa pura, pois ao passar pela extrusora a massa já perde muita umidade, dificultando a expansão na etapa seguinte, ou seja, na termoprensa. As FIG. 45 e 46 mostram as diferenças na expansão da massa pura (a) e da massa extrusada (b), de quantidades iguais, após termoprensagem de uma mesma formulação. 


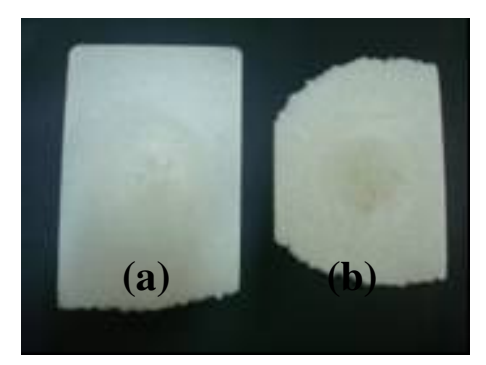

FIGURA 45 - Espumas sem ativos (formulação SAA) obtidas por termoprensagem de mesmas quantidades de massa pura (a) e massa extrusada (b).

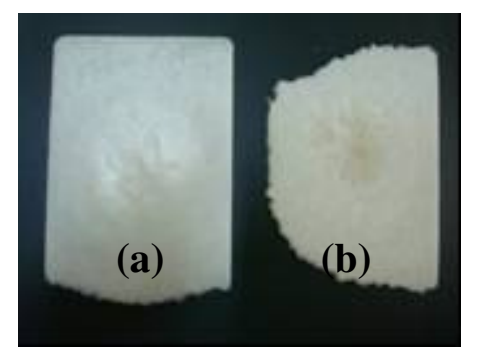

FIGURA 46 - Espumas com sorbato de potássio, incorporado ao gel (formulação SKG 15), obtidas por termoprensagem de mesmas quantidades de massa pura (a) e massa extrusada (b).

As espumas sem ativos (formulação SAA) e aquelas contendo os ativos (permanganato de potássio, sorbato de potássio e extratos naturais de beterraba e repolho roxo), obtidas pelos dois processos (termoprensagem e extrusão seguida de termoprensagem), também foram submetidas a ensaios mecânicos (tração e alongamento). Os resultados dos testes mecânicos estão apresentados na FIG. 47. 

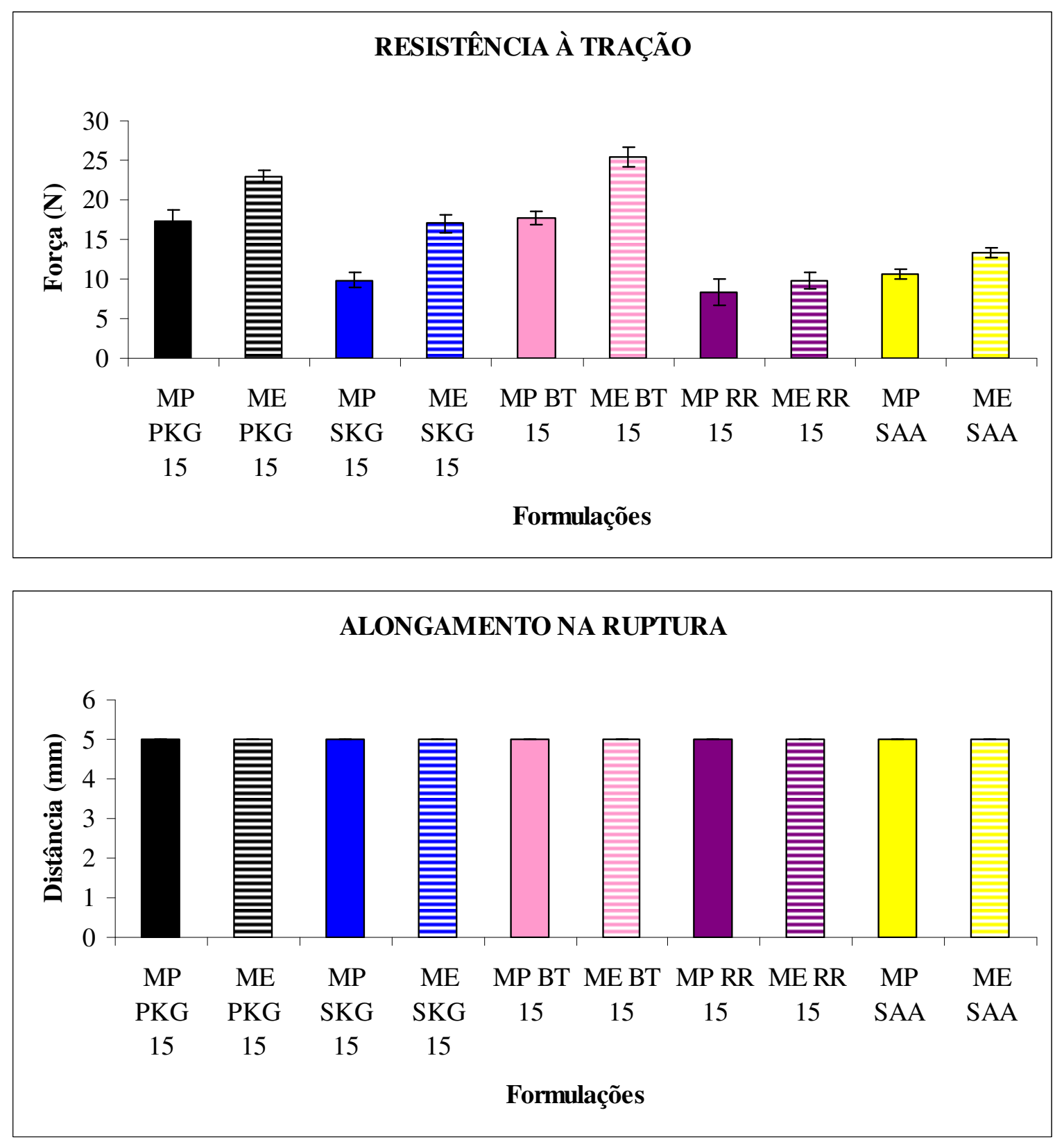

FIGURA 47 - Resistência à tração e alongamento na ruptura das espumas de fécula de mandioca com e sem ativos, obtidas pelos processos de termoprensagem e extrusão seguida de termoprensagem. $\mathrm{ME}=$ massa extrusada; $\mathrm{MP}=$ massa pura; $\mathrm{PKG} 15=15 \%$ de permanganato de potássio; SKG $15=15 \%$ de sorbato de potássio; BT $15=15 \%$ de extrato de beterraba; RR $15=15 \%$ de extrato de repolho roxo; $\mathrm{SAA}=$ espuma sem ativos.

As espumas de fécula de mandioca produzidas pelo processo de extrusão seguida de termoprensagem (formulações $\mathrm{ME)}$ ) foram mais resistentes à tração do que as produzidas somente por termoprensagem (formulações MP). Isso também pode ser explicado pela compactação da estrutura molecular da mistura (massa) ao passar pela 
extrusora. As formulações de massas pura e extrusada de extrato de repolho roxo (MP RR 15: 8,3 $\pm 1,6 \mathrm{~N}$ e ME RR 15: 9,8 $\pm 1,0 \mathrm{~N}$ ) mostraram ser as menos resistentes. Já as espumas de massa extrusada com permanganato de potássio (ME PKG 15: 23,0 \pm 0,7 N) e extrato de beterraba (ME BT 15: 25,4 \pm 1,2 N) foram as mais resistentes, sendo que a termoprensagem de suas massas puras apresentaram forças de 17,2 \pm 1,5 $\mathrm{N}$ (formulação MP PKG 15) e 17,7 \pm 0,8 N (formulação MP BT 15). As espumas sem ativos e as espumas com sorbato de potássio obtidas pelo processo de termoprensagem - de massa pura (formulações MP SAA e MP SKG 15) - resistiram, respectivamente, às forças de 10,6 \pm $0,6 \mathrm{~N}$ e 9,8 $\pm 0,9 \mathrm{~N}$, que, por sua vez, foram menos resistentes do que as obtidas pelo processo de extrusão seguida de termoprensagem (formulações ME SAA: 13,4 $\pm 0,6 \mathrm{~N} \mathrm{e}$ ME SKG 15: 17,0 \pm 1,2 N). De acordo com a análise estatística (ANOVA), ao comparar os dois processos para uma mesma formulação, só não houve diferença significativa entre as forças das espumas sem ativos (formulações MP SAA e ME SAA) e entre as forças das espumas com extrato de repolho roxo (formulações MP RR 15 e ME RR 15). Em relação ao alongamento, as espumas ativas (formulações SKG 15, PKG 15, RR 15 e BT 15) e aquelas sem ativos (formulação SAA), produzidas pelos dois processos estudados neste trabalho (formulações MP e ME), apresentaram o mesmo alongamento - 5,00 \pm 0,01 mm. 


\section{CONCLUSÕES}

Considerando-se as variáveis estudadas neste projeto, conclui-se que a melhor formulação para a produção de espumas de fécula de mandioca pelo processo de termoprensagem (apenas) foi a que continha maior quantidade de fécula (57\%) e polietilenoglicol (PEG 300) como plastificante, ou seja, uma mistura de gel (fécula suspensa em água), polietilenoglicol (2\% em peso dos sólidos) e fécula de mandioca sendo $10 \%$ fécula modificada fisicamente pelo processo de pré-gelatinização e o restante (47\%) fécula normal (sem modificação). Porém, ao analisar os diferentes processos de produção estudados, verificou-se que as espumas de fécula de mandioca produzidas pelo processo de extrusão seguida de termoprensagem foram mais resistentes à tração do que as produzidas somente por termoprensagem.

Quanto maior a concentração de fécula, mais resistente é a espuma. As espumas com 57\% de sólidos, ao saírem do molde, são menos quebradiças do que as com 55\%, pois absorvem mais água do que as outras. Como a água tem poder plastificante, as espumas com 57\% de sólidos são mais resistentes à tração, facilitando assim o manuseio das peças e evitando perdas durante a armazenagem. As espumas com o plastificante polietilenoglicol foram bastante flexíveis, apresentaram boa resistência à tração na ruptura e absorveram pouca água. A pré-gelatinização da fécula (modificação física) proporcionou melhores propriedades mecânicas e de barreira às espumas em relação aos outros tratamentos dados à fécula de mandioca. Já a adição dos agentes ativos não proporcionou tais melhoras às embalagens.

A adição de agentes ativos (sorbato de potássio e permanganato de potássio) e inteligentes (extratos de beterraba e repolho roxo) às espumas forneceu resultados satisfatórios, como: melhor preservação do alimento acondicionado (aumento de vida útil) e informação do grau de frescura do alimento pela mudança de cor da embalagem (espuma). No teste sensorial com mamão, as embalagens convencionais de isopor e polietileno foram as mais impróprias para a conservação da fruta, que apresentou, após 14 dias de refrigeração, $\mathrm{pH}$ inferiores aos daqueles acondicionados em espumas ativas de fécula de mandioca. Dentre as espumas de fécula de mandioca, os pedaços de mamão 
cobertos pela espuma contendo o agente ativo permanganato de potássio foram os que menos sofreram reações de deterioração, seguidos daqueles selados com espuma contendo o ativo sorbato de potássio.

As embalagens de fécula de mandioca, apesar de absorverem mais água, foram mais resistentes à tração do que as de poliestireno expandido (isopor). A propriedade de barreira (absorção de água) das embalagens (espumas) de fonte renovável pode ser melhorada por meio da impermeabilização com filmes também biodegradáveis. 


\section{REFERÊNCIAS BIBLIOGRÁFICAS}

ABAM - ASSOCIAÇÃO BRASILEIRA DE PRODUTORES DE AMIDO DE MANDIOCA. Bioplásticos de amido: um mercado de futuro - Junho/2006. Disponível em: <http://www.abam.com.br>. Acesso em: 8 Dezembro 2009.

ABIPLAST - ASSOCIAÇÃO BRASILEIRA DA INDÚSTRIA DO PLÁSTICO. Perfil da Indústria Brasileira de Transformação de Material Plástico - 2005. São Paulo: ABIPLAST, 2006. Disponível em: <http://www.abiplast.org.br>. Acesso em: 03 abril 2010.

ABRE - ASSOCIAÇÃO BRASILEIRA DE EMBALAGEM. Apresentação do setor Histórico, 2010. Disponível em: <http://www.abre.org.br>. Acesso em: 03 abril 2010.

ADEBOWALE, K. O.; AFOLABI, T. A.; OLU-OWOLABI, B. I. Functional, physicochemical and retrogradation properties of sword bean (Canavalia gladiata) acetylated and oxidized starches. Carbohydrate Polymers, v.65, p.93-101, 2006.

AMADEU, F. B.; SARAN, G. M.; LORENZO, H. C.; CASTRO, M. C.; FONSECA, S. A. Políticas Públicas e Resíduos na "Região Araraquara - São Carlos". In: ENCONTRO NACIONAL DE GESTÃO EMPRESARIAL E MEIO AMBIENTE, 2005, Rio de Janeiro, R.J. EBAPE/FGV; EAESP/FGV; FEA/USP, 2005. 1 CD-ROM.

AMASS, W.; AMASS, A.; TIGHE, B. A review of biodegradable polymers: uses, current developments in the synthesis and characterization of biodegradable polyesters, blends of biodegradable polymers and recent advances in biodegradation studies. Polymer International, v.47, p.89, 1998.

ANDERSEN P. J.; HODSON S. K. Thermoplastic starch compositions incorporating particulate filler component. US Patent $\mathrm{n}^{\circ} 6,231,970 ; 2001 \mathrm{a}$.

ANDERSEN P. J.; ONG S.; CHRISTENSEN B. J.; HODSON S. K. Compositions and methods for manufacturing starch-based compositions. US Patent $\mathrm{n}^{\circ} 6,168,857 ; 2001 \mathrm{~b}$.

APPENDINI, P.; HOTCHKISS, J. H. Review of antimicrobial food packaging. Innovative Food Science \& Emerging Technologies. v.3, p.113-126, 2002. 
ARAÚJO, J. M. A. Química de alimentos: teoria e prática. Viçosa: Imprensa Universitária da Universidade Federal de Viçosa, p. 283-285, 1995.

ASTM - AMERICAN SOCIETY OF TESTING MATERIALS. Standard practice for maintaining constant relative humidity by means of aqueous solution. Annual Book of ASTM Standards Des. E 104-85. (Reapproved 1996) Vol-11.3. Philadelphia, PA, 1997.

ASTM - Standard test method for tensile properties of paper and paperboard using constant-rate-of-elongation apparatus, D828-97, 1997.

AZEREDO, H.M.C.; FARIA, J.A.F.; AZEREDO, A.M.C. Embalagens Ativas para Alimentos. Ciência e Tecnologia de Alimentos. v.20, n.3, p. 337, 2000.

BARRETT, E.; BICKERSTAFFE, J. Packaging's role in society. In: LEVY, G. (ed) Packaging, Policy and the Environment. Maryland: Aspen Publishers, p.4763, 2000.

BAUMANN, H.; TILLMAN, A. The Hitch Hiker's Guide to LCA: an orientation in life cycle assessment methodology and application. Lund: Studentliteratur, 543p, 2004.

BELEIA, A.; MILLER, R. A.; HOSENEY, R. C. Starch gelatinization in sugar solutions. Starch/Starke, v.48, p.259-262, 1996.

BELLO-PÉREZ, L. A.; AGAMA-ACEVEDO, E; ZAMUDIO-FLORES, P. B.; MENDEZ-MONTEALVO, G.; RODRIGUEZ-AMBRIZ, S. L. Effect of low and high acetylation degree in the morphological, physicochemical and structural characteristics of barley starch. Food Science and Technology, v.43, p.1434-1440, 2010.

BERTHIER, H. C. Garbage, Work and Society. Resources, Conservation and Recycling. US: Elsevier Science, v.39, n.3, p.193-210, 2003.

BLASS, A. Processamento de polímeros. Florianópolis: Ed. Da UFSC, 1985.

BOBBIO, F. O.; BOBBIO, P. A. Introdução à química de alimentos. $2^{\circ}$ Edição. São Paulo: Varela, 1995.

BOBBIO, F. O.; BOBBIO, P. A. Introdução à química de alimentos. $3^{\text {a }}$ Edição. São Paulo: Varela, 2003.

BOBBIO, P. A.; BOBBIO, F. O. Material de Embalagem. In: BOBBIO, P. A.; BOBBIO, F. O. Química do processamento de alimentos. $3^{\circ}$ Edição. Campinas: Fundação Cargill, p. 189-202, 1984. 
BONNAS, D. S.; CHITARRA, A. B.; PRADO, M. E. T.; TEIXEIRA JÚNIOR, D. Qualidade do abacaxi cv. Smooth cayenne minimamente processado. Revista Brasileira de Fruticultura, Jaboticabal, v.25, n2, p. 206-209, 2003.

BRACKMANN, A., STEFFENS, C.A., SESTARI, I., NEUWALD, D.A., GIEHL, R.F.H. Armazenamento em atmosfera modificada e controlada de banana "Prata". Com absorção de etileno. Ciência e Agrotecnologia, Lavras, v.30, n.5, p.914-919, set/out, 2006.

BRANDÃO, L. S. Inibição da microbiota de exsudado de frango por nisina incorporada em sachês de celulose. Dissertação (mestrado) - Universidade Federal de Viçosa, Minas Gerais, 2001.

BUTARELO, S. S.; BELEIA, A.; FONSECA, I. C. B.; ITO, K. C. Hidratação de tecidos de raízes de mandioca (Manihot esculenta crantz.) e gelatinização do amido durante a cocção. Ciência e Tecnologia de Alimentos, [S.I], v.24, n.3, 2004.

CARR, L. G. Desenvolvimento de embalagem biodegradável tipo espuma a partir de fécula de mandioca. 2007. Tese (doutorado) - Escola Politécnica da Universidade de São Paulo, São Paulo, 2007.

CEREDA, M. P.; VILPOUX, O. F. Tecnologia, usos e potencialidades de tuberosas amiláceas Latino Americanas. São Paulo: Fundação Cargill (Culturas de Tuberosas Amiláceas Latino Americanas), v.3, p.711, 2003.

CHALÉAT, C. M.; MICHEL-AMADRY, G.; HALLEY, P. J.; TRUSS, R. W. Properties of a plasticised starch-blend - Part 2: Influence of strain rate, temperature and moisture on the tensile yield behaviour. Carbohydrate Polymers, v.74, p. 366-371, 2008.

CHANG, Y. P.; KARIM, A. A.; SEOW, C. C. Interactive plasticizing antiplasticizing effects of water and glycerol on the tensile properties on tapioca starch films. Food Hydrocolloids, Kidlington Oxford, v. 20, n. 1, p.1-8, 2006.

CHAPIRO, A. Chemical modifications in irradiated polymers. Nuclear Instruments and Methods Physics Research. Sec. B: Beam Interactions with Materials and Atoms, v.32, p. 111-114, 1988.

CHAUDHARY, A. L.; MILER, M.; TORLEY, P. J.; SOPADE, P. A.; HALLEY, P. J. Amylose content and chemical modification effects on the extrusion of thermoplastic starch from maize. Carbohydrate Polymers, v.74, p. 907-913, 2008.

CHEN, C. H.; KUO, W. S.; LAI, LS. Effect of surfactants on water barrier and physical properties of tapioca starch/decolorized hsian-tsao leaf gum films. Food Hydrocolloids, v.23, p. 714-721, 2009. 
CHEN, C. H.; LAI, L. S. Mechanical and water vapor barrier properties of tapioca starch/decolorised hsian-tsao leaf gum films in the presence of plasticizer. Food Hydrocolloids, v.22, p. 1584-1595, 2008.

CHEN, L.; GORDON, S. H.; IMAM, S. H. Starch graft poly(methyl acrylate) loose-fill foam: preparation, properties and degradation. Biomacromolecules, v.5, p.238-244, 2004.

CHIEN, P. J.; SHEU, F.; YANG, F. H. Effects of edible chitosan coating on quality and shelf life of sliced mango fruit. Journal of Food Engineering, v.78, p. 225-229, 2007.

CHITARRA, M. I. F. Processamento mínimo de frutas e hortaliças (apostila). Lavras: UFLA/FAEPE, p.113, 2000.

CIESLA, K.; ELIASSON, A. Influence of gamma radiation on potato starch gelatinization studied by differential scanning calorimetry. Radiation Physics and Chemistry, v.64, p. 137-148, 2002.

CINELLI, P.; CHIELLINI, E.; LAWTON, J. W.; IMAN, S. H. Foamed articles based on potato starch, corn fibers and poly(vinyl alcohol). Polymer Degradation and Stability, v.91, p.1147-1155, 2006.

COLTRO, L. Avaliação do Ciclo de Vida como instrumento de gestão (Livro). Campinas:CETEA/ITAL, ISBN 978-85-7029-083-0, p.75, 2007.

COUTINHO, B. C.; MIRANDA, G. B.; SAMPAIO, G. R.; DE SOUZA, L. B. S.; SANTANA, W. J.; COUTINHO, H. D. M. A importância e as vantagens do polihidroxibutirato (plástico biodegradável). Holos, p.76, 2004.

DA CUNHA, L. R.; SOARES, N. F. F.; ASSIS, F. C. C.; DE MELO, N. R.; PEREIRA, A. F.; DA SILVA, C. B. Desenvolvimento e avaliação de embalagem ativa com incorporação de lactase. Ciência e Tecnologia de Alimentos, v.27, Campinas, 2007.

DA RÓZ, A.L. Plástico Biodegradável preparado a partir de Amido, Polímeros, v.13, n.4, São Carlos, doi: 10.1590/S0104-14282003000400003, Oct./Dezembro. 2003. Disponível em: $\quad$ http://www.scielo.br/scielo.php?pid=S010414282003000400003\&script=sci_arttext Acesso em : 24/08/2009.

DEBET, M. R.; GIDLEY, M. J. Three classes of starch granule swelling: Influence of surface proteins and lipids. Carbohydrate Polymers, v.64 3, p. 452-465, 2006.

DURANGO, A. M.; SOARES, N. F. F.; ANDRADE, N. J. Microbiological evaluation of an edible antimicrobial coating on minimally processed carrots. Food Control, v.17, p. 336-341, 2006. 
ELOMAA, M.; ASPLUND, T.; SOININEN, P.; LAATIKAINEN, R.; PELTONEN, S.; HYVARINEN, S.; URTTI, A. Determination of the degree of substitution of acetylated starch by hydrolysis, H NMR and TGA/IR. Carbohydrate Polymers, v.57, p.261-267, 2004.

EMBRAPA - EMPRESA BRASILEIRA DE PESQUISA AGROPECUÁRIA. Disponível em: <http://www.cnpmf.embrapa.br/mandioca.htm>. Acesso em: Janeiro 2009.

ERLANDSSON, B.; KARLSSON, S.; ALBERTSSON, A. C. The mode of action of corn starch and a pro-oxidant system in LDPE: influence of thermo-oxidation and UV irradiation on the molecular weight changes. Polymer Degradation and Stability, v.55, p. 237-245, 1997.

FAMÁ, L.; GERSCHENSON, L.; GOYANES, S. Starch-vegetable fibre composities to protect food products. Carbohydrate Polymers, v.75, p. 230-235, 2009.

FAO - FOOD AND AGRICULTURE ORGANIZATION. Proceedings of the validation forum on the global cassava development strategy. vol. 6. Rome: International Fund for Agricultural Development, 2004.

FLEMMING, H. C. Relevance of biofilms for the biodeterioration of surfaces of polymeric materials. Polymer Degradation and Stability, v.59, p.309, 1998.

FONTEYNE, J. Packaging recovery and recycling policy in practice. In: LEVY, G. (ed) Packaging, Policy and the Environment. Maryland: Aspen Publishers, p. 205-247, 2000.

GERMER, S. P. M.; VIALTA, A.; MOURAD, A. L.; QUEIROZ, M. B.; PINTO NETO, M.; JUNQUEIRA, V. C. A. A indústria de alimentos $e$ o meio ambiente, Campinas: ITAL, 2002.

GHALI, Y.; IBRAHIM, N.; AZIZ, H. Modification of corn starch and fine flour by acid and gamma irradiation. Part 1. chemical investigation of the modified product. Starch/ Starke, v.31, p. 325-328, 1979.

GLENN, G. M.; ORTS, W. J.; NOBES, G. A. R. Effect of Starch, Fiber and $\mathrm{CaCO}_{3}$ on the Properties of Foams Made by a Baking Process. Industrial Crops and Products, v.14, p.201-212, 2001.

GUAN, J.; HANNA, M. A. Selected morphological and functional properties of extruded acetylated starch-cellulose foams. Bioresource Technology, v.97, p.1716-1726, 2006.

GUINEÉ, J.B., (Editor). Handbook on life cycle assessment - Operational guide to the ISO standards. Kluwer Academic Publishers/Springer, Dordrecht, the Netherlands, p.692, 2002. 
HALLEY, P.; MCGLASHAN, S.; GRALTON, J. Y. Biodegradable polymer. Plantic Technologies Ltd, United States Patent, \#7094817, Washington, August, 2006.

HAN, J. H. Active food packaging. Disponível em: <http://www.wmrc.com>. Acesso em: 03 abril 2010.

HAYASHI, T.; AOKI, S. Accumulation of sucrose in gamma-irradiated sweet potato roots. Journal of Agricultural and Food Chemistry. v.33, p. 14-17, 1985.

HENRY, F.; COSTA, L. C.; AYMES-CHODUR, C., Influence of ionizing radiation on physical properties of native and chemically modified starches, Radiation Physics and Chemistry, v.79, n.1, p.75-82, 2009.

HOFMANN, T.; LINKE, L.; TSIAPOURIS, A.; ZIEMS, A. Porous Materials Made from Starch. Chemical Engineering and Technology. v.21, p.580 - 584, 1998.

HOSENEY, R. Principles of Cereal: Science and Technology. $2^{\circ}$ Edição, USA: American Association of Cereal Chemists, 1999.

HUANG, S. J.; EDELMAN, P. G. Degradable Polymers: Principles and Applications. In: SCOTT, G.; GILEAD, D. (ed), Chapman \& Hall: London, 1995.

IBGE - INSTITUTO BRASILEIRO DE GEOGRAFIA E ESTATÍSTICA. Disponível em: $<$ http://www.ibge.br> . Acesso em: 3 junho 2010.

IDEC - INSTITUTO DE DEFESA DO CONSUMIDOR. Do lixo quase tudo se aproveita. Revista do IDEC on line, 2006. Disponível em: <http://www.idec.org.br> . Acesso em: 3 abril 2010.

JIANG, Y.; JOYCE, D. C.; MACNISH, A. J. Extension of the shelf life of banana fruit by 1-methylcyclopropene in combination with polyethylene bags. Postharvest Biology and Technology. Amsterdan, n.16, p.187-193. 1999.

KIM, J. K.; JO, C.; PARK, H. J.; BYUN, M. W. Effect of gamma irradiation on the physicochemical properties of a starch-based film. Food Hydrocolloids, v.22, p.248-254, 2008 .

KLUGE, R. A.; VITTI, M. C. D.; BASSETTO, E.; JACOMINO, A. P. Temperatura de armazenamento de Tangore "murcote" minimamente processado. Revista Brasileira de Fruticultura, Jaboticabal, v.25, n.3, p.535-536, 2003.

KOBER, E.; GONZALEZ, M. E.; GAVIOLI, N.; SALMORAL, E. M. Modification of water absorption capacity of a plastic based on bean protein using gamma irradiated starches as additives. Radiation Physics and Chemistry, v.76, p.55-60, 2007. 
KONG, X.; KASAPIS, S.; BAO, J.; CORKE, H. Effect of gamma irradiation on the thermal and rheological properties of grain amaranth starch. Radiation Physics and Chemistry, v.78, p.954-960, 2009.

KOROTCHENKO, K.A.; NADZHAFOVA, M.A.; SHARPATYI, V.A. Phizikokhimicheskie svoistva modifitzirovannykh polisacharidov. Izv. Vyssh. Uchebn. Zaved. Pisch. Teknol. (1), p.76-80, 1982.

KRISTO, E.; BILADERES, C. G.; ZAMPRAKA, A. Water vapour barrier and tensile properties of composite caseinate-pullulate films: biopolymer composition effects and impact of beeswax lamination. Food Chemistry, v.101, p.753-764, 2007.

LABUZA, T.P.; BREENE, W.M. Applications of "active packaging" for improvement of shelf-life and nutritional quality of fresh and extended shelf-life foods. Journal of Food Processing and Preservation, v.13, n.1, p.1-69, 1989.

LACROIX, M.; LE, T. C.; OUATTARA, B.; YU, H; LETENDRE, M; SABATO, S. F. Use of an irradiation to produce films from whey, casein, and soya proteins: structure and functional characteristics. Radiation Physics and Chemistry, v.63, p.827-832, 2002.

LAFARGUE, D.; LOURDIN, D.; DOUBLIER, J. L. Film-forming properties of a modified starch/(j-carrageenan mixture in relation to its rheological behavior). Carbohydrate Polymers, v.70, p.101-111, 2007.

LAROTONDA, F. D. S.; MATSUI, K. N.; SOLDI, V.; LAURINDO, J. B. Biodegradable films made from raw and acetylated cassava starch. Brazilian Archives of Biology and Technology, v.47, n.3, p.477-484, 2004.

LAWTON, J. W.; SHOGREN, R. L.; TIEFENBACHER, K. F. Effect of batter solids and starch type on the structure of baked starch foams. Cereal Chemistry, [S.I], v.75, n.5, p.682-687, 1999.

LEE, S. Y.; CHOI, J. Effect of fermentation of performance on the economics of poly(3hydroxybutylate) production by Alcaligenes latus. Polymer Degradation and Stability. [S.I], n.59, p.387-393, 1998.

LEONEL, M.; FREITAS, T. S.; MISCHAN, M. M. Physical characteristics of extruded cassava starch. Food Science and Technology, v.66, n.4, 2009.

LEVY, G. Introduction: Packaging, Policy and the Environment. In: LEVY, G. (ed) Packaging, Policy and the Environment. Maryland: Aspen Publishers, p.146, 2000. 
LIMA, A. S.; RAMOS, A. L. D.; MARCELLINI, P. S.; BATISTA, R. A.; FARAONI, A. S. Adição de agentes antiescurecimento, antimicrobiano e utilização de diferentes filmes plásticos, em mamão minimamente processado. Revista Brasileira Fruticultura. São Paulo: Jaboticabal, v.27, n.1, p.149-152, 2005.

LIU, H.; XIE, F.; YU, L.; CHEN, L.; LI, L. Thermal processing of starch-based polymers. Progress in Polymer Science, v.34, p.1348-1368, 2009.

LÓPEZ, O. V.; ZARITZKY, N. E.; GARCÍA, M. A. Physicochemical characterization of chemically modified corn starches related to rheological behavior, retrogradation and film forming capacity. Journal of Food Engineering, v.100, p.160-168, 2010.

LÓPEZ, O. V.; GARCÍA, M. A.; ZARITZKY, N. E. Film forming capacity of chemically modified corn starches. Carbohydrate Polymers. v.73, n.4, p.573-581, 2008.

LOURDIN, D.; COIGNARD, L.; BIZOT, H.; COLONNA, P. Influence of equilibrium relative humidity and plasticizer concentration on the water content and glass transition of starch materials. Polymer: The Chemistry, Physics And Technology of High Polymer, v.38, n.21, p.5401-5406, London, October, 1997.

MA, X. F.; YU, J. G.; KENNEDY, J. F. Studies on the properties of natural fibersreinforced thermoplastic starch composites. Carbohydrate Polymers, v.62, n.1, p.1924, 2005.

MADIVAL, S.; AURAS, R.; SINGH, S. P.; NARAYAN, R. Assessment of the environmental profile of PLA, PET and PS clamshell containers using LCA methodology. Journal of Cleaner Production, v.17, p.1183-1194, 2009.

MALI, S.; GROSSMANN, M. V. E.; GARCÍA, M. A.; MARTINO, M. M.; ZARITZKY, N. E. Barrier, mechanical and optical properties of plasticized yam starch films. Carbohydrate Polymers, Barking, v.56, p.129-135, 2004.

MALI, S.; SAKANAKA, L. S.; YAMASHITA, F.; GROSSMANN, M. V. E. Water sorption and mechanical properties of cassava starch films and their relation to plasticizing effect. Carbohydrate Polymers, Barking, v.60, p.283-289, 2005.

MATSUI, K. N.; LAROTONDA, F. D. S.; PAES, S. S.; LUIZ, D. B.; PIRES, A. T. N.; LAURINDO, J. B. Cassava bagasse-Kraft paper composites: analysis of influence of the impregnation with starch acetate on the tensile strength and water absorption properties. Carbohydrate Polymers, v.55, p.237-243, 2004.

MATTSSON, B.; SONESSON, U. (Ed.) Environmentally-friendly food processing. Cambridge: Woodhead Publishing Limited, p.337, 2003. 
MOURAD, A. L.; GARCIA, E. E. C.; VILHENA, A. Avaliação do ciclo de vida: princípios e aplicações. Campinas: CETEA/CEMPRE, p.92, 2002.

NARAYAN, R. Drivers and Rationale for use of biobased materials based on life cycle assessment (LCA). Global Plastics Environmental Conference, Atlanta, March, 2004.

NATIONAL STARCH \& CHEMICAL INDUSTRIAL Ltda. Como escolher: um guia profissional para amidos alimentícios. p.8, São Paulo, 1997.

NEMTANU, M. R.; MINEA, R.; KAHRAMAN, K.; KOKSEL, H.; NG, P. K. W.; POPESCU, M. I.; MITRU, E. Electron beam technology for modifying the functional properties of maize starch. Nuclear Instruments \& Methods in Physics Research, p.795798, 2007.

OLIVEIRA, L. M.; ARAUJO, E. S. ; GUEDES, S. M. L. Gamma irradiation effects on poly(hydroxybutyrate). Polymer degradation and stability, v.91, p. 2157-2162, 2006.

PACI, M.; LA MANTIA, F. P. Influence of small amounts of polyvinylchloride on the recycling of polyethylenetherephtalate. Polymer Degradation and Stability, v.63, p.11-14, 1999.

PALHARES, M. F. P. O impacto do marketing "verde" nas decisões sobre embalagens das cervejarias que operam no Brasil. Dissertação (Mestrado) São Paulo: FEA/USP, 2003.

PARRA, D. F.; TADINI, C. C.; PONCE, P.; LUGÃO, A. B. Mechanical properties and water vapour transmission in some blends of cassava starch edible films. Carbohydrate Polymers, v.58, p.475-481, 2004.

PICKLER MÁQUINAS E EQUIPAMENTOS LTDA. Disponível em: $<$ http://www.picklermaquinas.com.br>. Acesso em: Janeiro 2010.

PIETERS, R. Changing, garbage disposal patterns of consumers: motivation, ability,and performance. Journal of Public Policy and Marketing, v.10, US: AMA, 1991.

PIVA, A. M.; WIEBECK, H. Reciclagem do plástico: como fazer da reciclagem um negócio lucrativo. São Paulo: Artiliber Editora, p.112, 2004.

RABELLO, M. Aditivação de polímeros. São Paulo: Editora Artliber, 2000.

RAFFI, J.; AGNEL, J.P.; THIERY, C.J.; FRÉJAVILLE, C.M.; SAINT-LEBE, L. Study of gamma irradiated starches derived from different foodstuffs. Journal of Agricultural and Food Chemistry, v.29, p.1227-1232, 1981a. 
RAFFI, J.; DAUBERTE, B.; D.URBAL, M.; POLLIN, C.; SAINT-LEBE, L. Gamma radiolysis of starches derived from different foodstuffs. Part IV. Study of radiodepolymerization. Starch/Starke, v.33, p.301-306, 1981c.

RAFFI, J.; FRÉJAVILLE, C.M.; DAUPHIN, J.F.; DAUBERTE, B.; D.URBAL, M., SAINT-LEBE, L. Gamma radiolysis of starches derived from different foodstuffs. Part II. Study of induced acidity. Starch/Starke, v.33, p.235-240b, 1981 b.

RAFFI, J.; MICHEL, J.P.; SAINT-L.EBE, L. Experimental study of the radiodepolymerization of starch. Starch/Starke, v.32, p.295-298, 1980.

RAGHEB, A. A.; EL-THALOUTH, I. A.; TAWFIK, S. Gelatinization of starch in aqueous alkaline solutions. Starch/Starke, v.48, p.57, 1996.

RESSOUANY, M.; VACHON, C., \& LACROIX, M. Irradiation dose and calcium effect of the mechanical properties of cross-linked caseinate film. Journal of Agricultural and Food Chemistry, v.46, p. 1618-1623, 1998.

ROSA, D. S.; LOTTO, N. T.; LOPES, D. R.; GUEDES, C. G. F. The use of roughness for evaluating the biodegradation of poly- $\beta$-(hydroxybutyrate) and poly- $\beta$-(hydroxybutyrateco- $\beta$-valerate). Polymer Testing, v.23, p.3-8, 2004.

SALGADO, P. R.; SCHMIDT, V. C.; ORTIZ, S. E. M.; MAURI, A. N.; LAURINDO, J. B. Biodegradable foams based on cassava starch, sunflower proteins and cellulose fibers obtained by a baking process. Journal of Food Engineering, v.85, p.435-443, 2008.

SARANTÓPOULOS, C. I. G. L.; ALVES, R. M. V. A.; OLIVEIRA, L. M. Embalagens com atmosfera modificada. Campinas: CETEA/ITAL, 1996.

SARANTÓPOULOS, C. I. G. L.; FERNANDES, T. Embalagens ativas: uma nova geração de embalagens para frutas e hortaliças. Boletim Técnico do Centro de Tecnologia de Embalagens, v.13, n.3, p.4-6, 2001.

SARZI, B.; DURIGAN, J.F. Avaliação física e química de produtos minimamente processados de abacaxi "pérola". Revista Brasileira de Fruticultura. Jaboticabal, v.24, n.2, p.333-337, 2002.

SHEY, J.; IMAM, S. H.; GLENN, G. M.; ORTS, W. J. Properties of baked starch foam with natural rubber latex. Industrial Crops and Products, v.24, p.34-40, 2006.

SHOGREN, R. L.; LAWTON, J. W.; DOANE, W. M.; TIEFENBACHER, K. F. Structure and morphology of baked starch foams. Polymer, v.39, p.6649-6655, 1998. 
SHOGREN, R.L.; LAWTON, J. W.; TIEFENBACHER K.F. Baked starch foams: starch modifications and additives improve process parameter, structure and properties. Industrial Crops and Products, Amsterdam, v.16, n.1, p.69-79, 2002.

SHOGREN, R. L. Preparation, thermal properties, and extrusion of high-amylose starch acetates. Carbohydrate Polymers, v.29, n.1, p.57-62, 1996.

SILVA JÚNIOR, A.; VASCONCELOS, P. M.; MESQUITA FILHO, J. A. Processamento de frutas. Fortaleza: Instituto e Centro de Ensino Tecnológico, p.10-11, 2003.

SILVA, R. M.; FERREIRA, G. F.; SHIRAI, M. A.; HAAS, A.; SCHERER, M. L.; FRANCO, C. M. L.; DEMIATE, I. M. Características físico-químicas de amidos modificados com permanganato de potássio/ácido lático e hipoclorito de sódio/ácido lático. Ciência e Tecnologia de Alimentos, v.28, p.66-77, 2008.

SINGH, J; KAUR, L.; McCARTHY, O. J. Factors influencing the physico-chemical, morphological, thermal and rheological properties of some chemically modified starches for food applications - A review. Food Hydrocolloids, v.21, p.1-22, 2007.

SIRACUSA, V.; ROCCULI, P.; ROMANI, S.; ROSA, M. D. Biodegradable polymers for food packaging: a review. Trends in Food Science and Technology, v.19, p.634-643, 2008 .

SOARES, N. F. F. Bitterness reduction in citrus juice through naringinase immobilized into polymer film. Ph. D. Dissertation. New York: Cornell University, 1998.

SOUZA, R. C. R.; ANDRADE, C. T. Investigação dos processos de gelatinização e extrusão de amido de milho. Polímeros: Ciência e Tecnologia, v.10, p.24-30, 2000.

SOYKEABKAEW N., SUPAPHOL P., RUJIRAVANIT R. Preparation and characterization of jute and flax reinforced starch-based composite foams. Carbohydrate Polymers, p.1-11, 2004.

STEENEKEN, P. A. M.; WOORTMAN, A. J. J. Superheated starch: A novel approach towards spreadable particle gels. Food Hydrocolloids, v.23, p.394-405, 2009.

STRATHMANN, S.; PASTORELLI, S.; SIMONEAU, C. Investigation of the interaction of active packaging material with food aroma compounds. Sensors and Actuators B: Chemical, v.106 (1), p.83-87, 2005.

TANG, X.; ALAVI, S.; HERALD, T. J. Barrier and mechanical properties of starchclay nanocomposite films. Cereal Chemistry, v.85, p.433-439, 2008a. 
TANG, X.; ALAVI, S.; HERALD, T. J. Effects of plasticizers on the structure and properties of starch-clay nanocomposite films. Carbohydrate Polymers, v.74, p.552- 558, 2008b.

TOVAR, L.; SALAFRANCA, J.; SÁNCHEZ, C.; NERIN, C. Migration Studies To Assess the Safety in Use of a New Antioxidant Active Packaging. Journal of Agricultural and Food Chemistry, v.53 (13), p.5270-5275, 2005.

VALT, R. B. G. Análise do Ciclo de Vida de embalagens de PET, de alumínio e de vidro para refrigerantes no Brasil variando a taxa de reciclagem dos materiais. Tese (Mestrado), Setor de Tecnologia, Curitiba: Universidade Federal do Paraná, 2004.

VAN DUIN, M.; MACHADO, A. V.; COVAS, J. A look inside the extruder: evolution of chemistry, morphology and rheology along the extruder axis during reactive processing and blending. Macromolecular Symposia, v.170, p.29-39, 2001.

VAN SOESTE, J. J. G.; DE WIT, D.; VLIEGENTHART, J. F. G. Mechanical properties of thermoplastic waxy maize starch. Journal of Applied Polymer Science, v.61, p.19271937, 1996.

VERMEIREN, L.; DEVLIEGHERE, F.; VAN BEEST, M.; DE KRUIJF, N.; DEBEVERE, J. Developments in the active packaging of foods. Trends Food Science And Technology, v.10, n.3, p.77-86, 1999.

WASIK, J. F. Green marketing and management: a global perspective. UK: Blackwell, p.212, 1996.

WILLETT, J. L.; SHOGREN, R. L. Processing and properties of extruded starch/polymer foams. Polymer. v.43, p.5935-5947, 2002.

WILLIAMSON, G. H. Packaging and environmental legislations: The European community. In: LEVY, G. (ed) Packaging, Policy and the Environment. Maryland: Aspen Publishers, p.131-152, 2000.

WOODS, T. BEYNON, D. Managing the environmental impacts of packaging manufacture. In: LEVY, G. (ed) Packaging, Policy and the Environment. Maryland: Aspen Publishers, p.153-177, 2000.

WURZBURG, O. B. Cross-linking starches. In: WURZBURG, O. B. Modified starches: properties and uses. Boca Raton: CRC Press, p.41-53, 1986.

XU, X.; GUO, S. A. A study on morphological structure of low molecular weight PVC prepared by vibromilling degradation. Polym. Plastics Technology and Engineering, v.34, p.621-632, 1995. 
YAMASHITA, F.; NAKAGAWA, A.; VEIGA, G. F.; MALI, S.; GROSSMANN, M.V.E. Embalagem ativa para frutos de acerola. Brazilian Journal of Food Technology, v.9, n.2, p.1-8, 2006.

ZANIN, M.; MANCINI, S. D. Resíduos Plásticos e Reciclagem: aspectos gerais e tecnologia, São Carlos: EdUFSCar, 2004.

ZHAI, M.; YOSHII, F.; KUME, T. Radiation modification of starch-based plastic sheets. Carbohydrate Polymers, v.52, p.311-317, 2003.

ZITNY, R.; SESTAK, J.; TSIAPOURIS, A.; LINKE, L. Modeling of thermal pressure forming of starch based materials. Journal of Food Engineering, v.52, p.375-385, 2002. 